\title{
1 The Thiem team - Adolf and Günther Thiem, two forefathers of 2 hydrogeology
}

3 Georg J. Houben ${ }^{1}$, Okke Batelaan ${ }^{2}$

$4 \quad{ }^{1}$ Federal Institute for Geosciences and Natural Resources (BGR), Hannover, Germany

$5 \quad{ }^{2}$ National Centre for Groundwater Research and Training (NCGRT), College of Science \& Engineering, Flinders University, 6 Adelaide, SA 5001, Australia Correspondence to: Georg Houben (Georg.Houben@bgr.de)

8 Abstract. Adolf and Günther Thiem, father and son, left behind a methodological legacy that many current hydrogeologists

9 are probably unaware of. It goes much beyond the Dupuit-Thiem analytical model for pump test analysis, which is connected 10 to their name. Methods, which we use on a day-to-day basis today, such as isopotential maps, tracer tests and vertical wells were amongst the many contributions which the Thiems either developed or improved. Remarkably, this was not done in a university context but rather as a by-product of their practical work designing and building water supply schemes in countries all over Europe. Some of these water works are still active. Both Thiems were also great science communicators. Their contributions were read and applied in many countries, especially in the US, through a personal connection between Günther and O.E. Meinzer, the leading USGS hydrogeologist of the time.

Keywords

Adolf Thiem, Günther Thiem, O.E. Meinzer, history, pumping test, well construction

\section{Introduction}

The name Thiem appears in many hydrogeological textbooks, most often in the context of the Dupuit-Thiem method, an analytical model for the evaluation of steady-state pumping tests. Few hydrogeologists, however, are aware that there were two engineers of this name, father and son, Adolf and Günther Thiem. Both contributed much more to the current hydrogeological methods than just a somewhat outdated pumping test model. Their work laid the foundations for a diversity of applications and methods still being used today, e.g., tracer tests, well construction, and isopotential maps, and was widely acknowledged even on the international scale, especially in the US. They also planned and supervised the construction of many groundwater supply schemes in several European countries, some of which are still active today, although in modernized form. The focus of this study is thus to investigate the scientific biography of both Thiems and how their contributions found their way into the international canon of methods. 


\subsection{Biography}

Adolf Thiem was born on February 21, 1836, under the full name of Friedrich Wilhelm Adolf Thiem in the town of Liegnitz (now Legnica, Poland) in the Prussian province of Silesia, where he obtained his high school diploma (Herfried Apel, pers. comm.; Anonymous, 1906). His family had been living in Liegnitz at least since the $18^{\text {th }}$ Century. His father was the eponymous Friedrich Wilhelm Adolf Thiem (born 1804), who married Johanna Natalie Julianne Thiem, nee Küpper in 1835. The family was of a craftsman background, but all were self-employed; the father was a master plumber, the grandfather Gottlieb Wilhelm a master nail smith, and the great-great-grandfather Johann a master cartwright. Adolf had a younger brother, Paul Thiem (born 1841 in Liegnitz, died 1883 in Munich), who also became an engineer. Adolf left his parents' house at the age of 14 for apprenticeship and self-study (Vieweg, 1959). He never attended a university but became an autodidact. At the age of 25, he published his first paper in the influential Journal für Gasbeleuchtung (Thiem, 1861), where he introduces himself as an inspector at the gas works of his hometown Liegnitz, a job he still held at least into the following year (Thiem, 1862). In his 1863 paper in the same journal, he signs as inspector of the gas works of the much larger town of Munich (Thiem, 1863), a job he kept until 1865. The early papers already show his mathematical proficiency and his will to improve technical concepts (Thiem, 1861, 1864, 1866). Through contact with Nicolaus Schilling (1826-1894), founder of the now renamed Journal für Gasbeleuchtung und Wasserversorgung (Journal for gas lighting and water supply, based in Munich), he was recommended to Heinrich Gruner (1833-1906), a German engineer based in Basel, Switzerland, at that time. Gruner had mainly built gas works so far but wanted to expand into the water supply market and hired Thiem as an assistant in 1865 (Mommsen, 1962). Gruner introduced the aspiring Thiem to some fundamental French literature, including the works by Henry Darcy (1856) and Jules Dupuit $(1854,1863)$. His first work assignments led Thiem to the French town of Beaucourt, near Belfort, where he built spring captures and pipelines, and to Winterthur, Switzerland. After a bumpy start, Thiem proved to be an excellent technician, and in 1868 Gruner made him his partner and head of the branch office in Dresden (Mommsen, 1962). The company was called "Heinrich Gruner \& Thiem, Ingen. und Unternehmer von Wasseranlagen” (Engineers and entrepreneurs of water schemes). Thiem was mainly tasked with obtaining a share of the quickly expanding market for water supply in Germany. Again, after a bumpy start, Thiem managed to acquire several contracts, mainly convincing his clients through his technical competence. One of the projects was for the historic mining town of Freiberg, Saxony, where he installed a dual system in 1871, consisting of separate spring-fed drinking water and a service water network (Grahn, 1883, 1902). Gruner, however, was not equally happy since Thiem showed much less enthusiasm for financial issues and the day-to-day supervision of the construction sites than for the technical details. Therefore, he decided to move to Dresden himself in 1873 to regain control (Mommsen, 1962). Together, they designed and built the water supply schemes for the cities of Zwickau (1875) and Regensburg (1875), both fed by springs. For the latter, they relocated their company to this town in 1874. In the newspaper announcements from this time, Thiem is mentioned as "Ingenieur von Kamburg, Sachsen-Meiningen” (engineer from the city of Kamburg, Duchy Saxony-Meiningen), where he must have lived briefly. The Regensburg scheme was a technical challenge 
since it involved capturing springs located in a river bed, which needed to be protected from the river water itself. Additionally, the pipeline had to be laid through the bed of the Danube and Regen Rivers, which they accomplished by the intensive use of divers (Thiem, 1877; Mommsen, 1962). It was not unusual that such projects were financed by issuing stock for a designated public water supply company, in this case with a value of 1,028,400 German Mark, of which the Gruner \& Thiem company assumed a substantial share of 340,000 Mark (Grahn 1902). The project was so time-consuming that Thiem moved his family to Regensburg. He had married Luisa Thekla Groß (born 1852 in Zöblitz, died 1931 in Leipzig) in 1871 in Freiberg, while working there. All his three children were born in Regensburg: Paul Adolf (1874-1907), Ernst Gerhard Günther (1875-1959) and Katharina Else (1876-?) (Mommsen, 1962; Hoffmann, 2017). Gruner and Thiem's first truly groundwater-based supply system was the one for the city of Augsburg (1873-1879). Groundwater head observations for this study were already plotted in the form of an isopotential map.

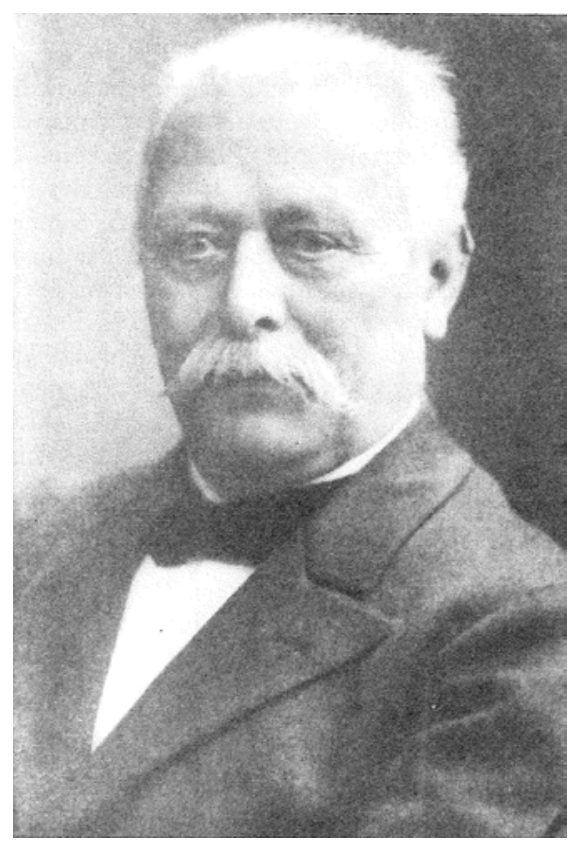

Figure 1: Adolf Thiem around the year 1900 (Franke and Kleinschroth, 1991).

Pumping tests, using observation wells to investigate the aquifer response, were already performed by the German engineer Bernhard Salbach (1833-1894) in Halle, Germany, in 1866 (Houben, 2019). Thiem's significant improvement, first applied in Augsburg, was the comparison of the drawdown to predictions by the Dupuit-Thiem model, which he had published previously (Thiem, 1870, see below). This was probably the first pumping test subjected to a rigorous mathematical evaluation. Another pumping test in Strassburg, Alsace, received more attention since its results were published in much more detail (Thiem, 1876b). Through their work in Augsburg and Strassburg, Thiem had clearly set the standard for identifying and quantifying 
groundwater resources. But he also considered the basic engineering problems of water supply, e.g., the design of pipeline networks (Thiem, 1876a, 1883a, 1884a, 1885b,c, 1915).

The conflicts between Gruner and Thiem had not abated. Thiem considered himself the underappreciated and underpaid workhorse, and in 1876 the partnership was dissolved (Mommsen, 1962). Both, independently of each other, moved to Munich, where several concepts for a central water supply were being considered. Thiem favoured groundwater, based on an intensive investigation in the fluvial Gleisenthal aquifer and published a detailed report (Thiem, 1878). In the end, the city council selected a concept proposed by Bernhard Salbach, based on karst springs located $38 \mathrm{~km}$ away in the Alps, due to their high yield, pristine water quality, and the fact that the system was purely gravitational. This proved to be a wise decision since the system is still the backbone of the city's water supply today. After the split from Gruner, Thiem successfully promoted himself by advertising the projects with Grunner as his own exploits. An irate Gruner felt obliged to publish a piece in a Munich newspaper, denouncing Thiem as a mere assistant, whose responsibility had been to travel, acquire projects, take measurements, and prepare calculations, which then had to be submitted to Gruner (Gruner 1876).

\section{(1)}

In 1886, following an invitation by the city mayor Otto Georgi, Thiem moved for the last time to Leipzig. In the first year, they lived in the Kramerstraße but then moved into the newly built "Haus Pommer” at Hillerstraße Nr. 9 in 1887, which was to become the Thiem family residence at least until the late 1950s. His consulting company, which at the turn of the century figured as “A. Thiem \& Söhne, Civilingenieure” (A. Thiem \& sons, Civil engineers, Mommsen, 1962) became so successful that he had to rent a separate office already in 1891, located at the Thomaskirchhof 18, right in the city centre, which he later moved to Quaistraße 2 in 1902 (today Carl-Maria von Webern-Straße). The company employed up to twelve people, including his two sons. His older son Paul Adolf, a graduated civil and mechanical engineer died in December 1907, aged only 33, a few months before Adolf (Anonymous, 1908). Adolf Thiem was the leading planner of the groundwater supply scheme for several larger cities (Table 1), including his new hometown Leipzig, which was expanded in several stages (Thiem, 1881, 1906, 1908). 
115 Table 1: Main water supplies planned and built by Adolf Thiem (English names in parentheses)

\begin{tabular}{|c|c|c|c|}
\hline Name of city & Name of city today & Comment & References \\
\hline Freiberg & & 1871, with Gruner & Grahn $(1883,1902)$ \\
\hline Zwickau & & with Gruner & $\begin{array}{l}\text { Grahn 1902, } \\
\text { Mommsen (1962) }\end{array}$ \\
\hline Regensburg & & with Gruner & Thiem (1877a) \\
\hline Augsburg & & with Gruner & $\begin{array}{lr}\text { Gruner } & \text { and } \text { Thiem } \\
\text { (1874), } & \text { Mommsen } \\
(1962) & \end{array}$ \\
\hline Strassburg & Strasbourg, France & then Germany & Thiem (1876) \\
\hline München (Munich) & & not built & $\begin{array}{l}\text { Thiem (1877b, 1880d, } \\
\text { 1914) }\end{array}$ \\
\hline $\begin{array}{l}\text { Nürnberg } \\
\text { (Nuremberg), also } \\
\text { Fürth }\end{array}$ & & & Thiem (1879a, 1881a) \\
\hline Riga & & $\begin{array}{l}\text { then Russia, today } \\
\text { Latvia }\end{array}$ & $\begin{array}{l}\text { Salm (1893), Thiem } \\
\text { (1883b, 1888e) }\end{array}$ \\
\hline Leipzig & & & 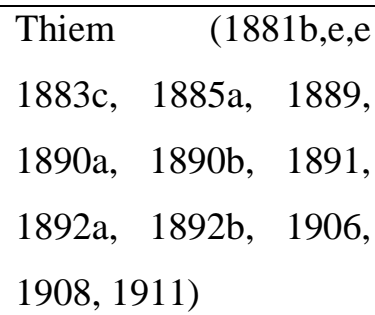 \\
\hline Gera & & & $\begin{array}{l}\text { Thiem (1884c), Grahn } \\
\text { (1902) }\end{array}$ \\
\hline Stralsund & & not built & Thiem (1888d) \\
\hline Malmö, Sweden & & 1890, with J.G. Richert & Svensson (2013) \\
\hline Potsdam & & & Thiem (1892d) \\
\hline Charlottenburg & & now part of Berlin & Thiem (1897a, 1913a) \\
\hline Mainz & & incl. Laubenheim & $\begin{array}{l}\text { Thiem (1897b,c), } \\
\text { Grahn (1902) }\end{array}$ \\
\hline
\end{tabular}




\begin{tabular}{|l|l|l|l|}
\hline Dessau & & 1897 & $\begin{array}{l}\text { Grahn (1902), Pfeffer } \\
(1906)\end{array}$ \\
\hline Breslau & Wrocław, Poland & then Germany & Anonymous (1902) \\
\hline Prag (Prague) & Praha, Czech Republic & then Austria-Hungary & Anonymous (1903) \\
\hline $\begin{array}{l}\text { Braunschweig } \\
\text { Brunswik) }\end{array}$ & & & $\begin{array}{l}\text { Grahn (1902), von } \\
\text { Feilitzsch (1904) }\end{array}$ \\
\hline Waldenburg & Wałbrzych, PL & then Germany & Lummert (1905) \\
\hline Landeshut & Kamienna Góra, PL & then Germany & Thiem (1909) \\
\hline
\end{tabular}

116

Other cities in Germany he was working for include - in alphabetical order - Biebrich, Blasewitz, Crimmitschau, Eilenburg, Essen, Frankenstein (Ząbkowice Śląskie, PL), Greifswald, Harburg/Hamburg, Hirschberg (Jelenia Góra, PL), Hohenstein, Kiel, Liegnitz (Legnica, PL), Limbach, Magdeburg (Thiem \& Fränkel 1902), Mansfeld, Markranstädt, Meerane, Metz, Mittweida, Oels (Oleśnica, PL), Plauen, Posen (Poznan, PL), Warmbrunn (Cieplice Śląskie-Zdrój, PL), Wismar and Zeitz (Grahn 1902; Anonymous, 1906; Dyck, 1986). His expertise was also valued abroad (Anonymous, 1906, 1952; Dyck, 1986) and, additional to the entries in Table 1, led him to work in Romania (Bucharest, Czernowitz, Klausenburg/Cluj-Napoca), Scandinavia (Åbo/Turku, Finland, Malmö (Sweden), and Porto Alegre (Brazil). His work was not restricted to studies of aquifers and wells but also encompassed the hydraulics of pipeline networks, the improvement of pumps, the development of water treatment techniques (especially iron removal) and even the construction of water towers, e.g. the still existing tower in Strasbourg from 1878, the first with a semi-spherical wrought iron tank (Thiem, 1876, 1877a, 1878, 1880c, 1883a, 1884a, 1885b, 1896, 1897a, 1894b, 1898b, 1915, 1929q; Grahn and Thiem, 1885). He briefly worked on inland navigation, in particular on the hauling of cargo vessels, on the Hohensaaten-Spandau canal near Berlin, work that was presented in a conference in Paris in 1892 (Thiem 1892c). Curiously, his home base is given as Eberswalde. He offered his clients the full package, ranging from groundwater exploration to planning and construction of wells and pipeline networks, water treatment plants and storage tanks, including economic considerations (Thiem, 1884b). He was probably one of the first to use the term "sustainability" (Nachhaltigkeit) in the context of groundwater (Thiem, 1881a). He had observed the groundwater levels in observation wells located along the Leipzig-Grimma train track over the course of 15 years. The relatively stable drawdowns led him to the conclusion that the drawdown caused by the extraction for the Leipzig water supply had become stable and extraction was thus sustainable (Thiem, 1881a).

In 1892, Thiem received the honorary title of “Königlich Sächsischer Baurat” (Royal Saxonian building officer). Probably in 1899, he received the “Königlich Sächsischer Verdienst-Orden” (Royal Saxonian Order of Merit), as of 1900 he proudly added the title "Ritter 2c" (knight, second class) to his entry in the Leipzig address book. A striking feature of his work ethic was that he never took out any patent, in order to foster the advancement of science (Anonymous, 1906, 1952). When asked about it by 
his pupils, he would smile and answer "Dies ist für die Allgemeinheit und nicht für mich alleine da. (This is for the public and not for me alone)" (Anonymous 1952). However, this claim is not entirely true since he took at least one patent on a water valve that would automatically close after a sudden pressure loss, e.g. caused by a pipeline rupture (Thiem, 1894a). On his 70th birthday, he was honoured by a page-long biographical sketch in the Journal für Gasbeleuchtung und Wasserversorgung, which states his role as founding father of hydro(geo)logy (Anonymous, 1906). Adolf Thiem died after short but severe suffering at the age of 72 in Leipzig on May 2, 1908 (Anonymous, 1908). He was buried there on the Südfriedhof in an honorary grave that still exists (Fig. 2). It is only a few meters away from the still active Probstheida water works and its impressive water tower, which Thiem designed shortly before his death. In 1912, the city of Leipzig named a street after him (Thiemstraße), which still bears this name today and leads to the Probstheida water works (Fig. 2). Several important German hydrologists such as Emil Prinz, Max Rother and his son, Günther Thiem were his pupils. In Germany, his legacy was recognized and kept alive, evidenced by several commemorative articles (Thiem, 1929q; Prinz, 1936; Anonymous 1949; Anonymous 1952; Anonymous 1958; Vieweg 1958a,b, 1959; Dyck, 1986; Engemann, 1989). As late as 1956, his seminal 1870 publication was reprinted (Thiem 1956).

Thiem's contributions to the growing field of hydrogeology were also noted outside Germany, already during his lifetime. His work for the water supply of Leipzig was considered important enough to be presented at the world exhibition in Chicago in 1893 (Hillger, 1893). In their 1899 book on groundwater flow, Franklin Hiram King and Charles Sumner Slichter cite seven of A. Thiem's papers, including those on tracer tests and other German papers by Lueger and Hagen (King and Slichter, 1899).
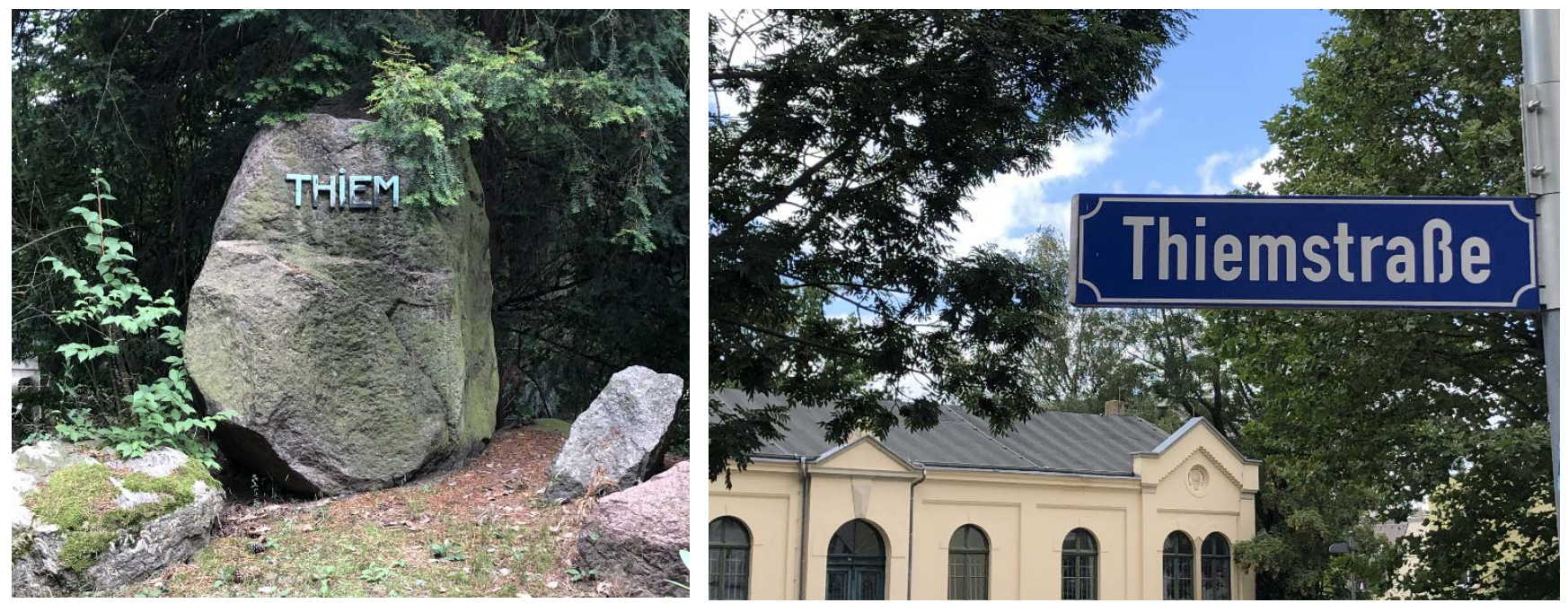

Figure 2: (left) Grave of honour of the Thiem family at the Südfriedhof, Leipzig. The gravestone is an erratic block found during the construction of the neighbouring monument (Völkerschlachtdenkmal) commemorating the decisive Battle of Leipzig against Napoleon 1813, (right) road sign of the Thiemstraße (Straße = street) in Leipzig (Photos: Houben). 


\subsection{Contributions to pumping tests}

164

165

The analytical model describing the radial flow of groundwater to a well embedded in a horizontal circular island aquifer is sometimes called the Dupuit model after Jules Dupuit (1863), sometimes the Thiem model after Adolf Thiem (1870) or Günther Thiem (1906), and sometimes the Dupuit-Thiem model. It is therefore important to compare the seminal contributions. After analysis of open-channel flow, in chapter VIII of his 1863 publication, Dupuit turned his attention to flow in permeable soil (Du mouvement de l'eau travers les terrains perméables). Based on his work on open channel flow, Dupuit stated that the slope of a groundwater table should follow a parabolic equation of the type of Equation 1:

$\mathrm{i}=\alpha \cdot \mathrm{Q}+\beta \cdot \mathrm{Q}^{2}$

Where $\mathrm{i}$ is the slope, $\mathrm{Q}$ is the flow rate, and alpha and beta are coefficients. This is basically identical to the later Forchheimer equation (Forchheimer, 1901). However, Dupuit realized that the velocity term $\beta \cdot Q^{2}$ could be ignored due to the commonly very low flow velocities of groundwater. Assuming a radial symmetry and a horizontal aquifer, he then derived the fundamental equations describing groundwater flow to a well at steady state, for both water table and artesian aquifers. Thiem (1870) had clearly read Dupuit's paper, as he duly cites it and ends his paper with a literal quote in French from Dupuit. Günther Thiem claimed that his father had actually been a friend of Dupuit, which is technically possible since Dupuit died in 1876, well after the 1870 publication by Adolf (Thiem, 1951). There is, however, no other evidence that both knew each other, apart from Günther's claim. Thiem's paper follows parts of the outline of Dupuit's chapter VIII closely. So, was Thiem, just a copycat? Not quite! In his equations, Dupuit used two heights of the water table above the impermeable aquitard, (1) $\mathrm{h}_{0}$ in the well itself at the well radius $\mathrm{r}_{0}$ (la hauteur de l'eau dans le puit) and (2) $\mathrm{H}$ at the outer radius of the cone of influence (la hauteur de l'eau extérieure) at a radius $\mathrm{R}$ (le rayon du massif filtrant). While the choice of these two points was sufficient for the mathematical derivation, they both were a rather poor choice from a practical point of view. The water levels in the well were often affected by additional, non-laminar head losses caused by the well tubing itself, something which Dupuit was aware of (see below) but chose to ignore. He also gave no practical hints on how to obtain the outer limit. He only realized that the value for the outer radius is of limited influence as it appears in a logarithmic term $\left(\log \left(\mathrm{R} / \mathrm{r}_{0}\right)\right)$. As such, the equations were of limited practical use and were not taken up by practitioners.

It was Adolf Thiem's merit to have grounded the Dupuit equation in the real world. He used two observation wells located within the cone of depression at different radii $r_{1}$ and $r_{2}$, thus avoiding the problems of turbulent losses in the well and of finding the radius of influence. While Dupuit (1863) takes precedence for the mathematical derivation (Ritzi and Bobeck, 2008), Thiem (1870) and his later papers (e.g. Thiem, 1876b) converted the method into a practical tool and popularized it. It 
is thus justified to call the method the Dupuit-Thiem model. Remarkably, his first-ever paper on groundwater became a classic.

$195 h_{2}-h_{1}=\frac{Q}{2 \cdot \pi \cdot K_{\mathrm{aq}} \cdot B} \cdot \ln \left(\frac{r_{2}}{r_{1}}\right)$

196 with

$197 h_{1}, h_{2}=$

$=\quad$ head at radial distance $r_{1}, r_{2}[\mathrm{~L}]$

$198 Q=$

pumping rate $\left[\mathrm{L}^{3} / \mathrm{T}\right]$

$199 K_{\mathrm{aq}}=$

hydraulic conductivity $[\mathrm{L} / \mathrm{T}]$

$200 B=$

constant thickness of confined aquifer [L]

$201 r_{1}, r_{2}=$

radius from well axis, with $r_{1}<r_{2}[\mathrm{~L}]$

Although the first well-documented pumping test in Germany was performed in 1866 in Beesen near Halle/Saale by Bernhard Salbach (Houben, 2019), Adolf Thiem's work defined some of the standard procedures. Already for his first pumping tests in Augsburg, Strassburg/Alsace und Munich he developed several approaches that are still in use today (Thiem, 1876b, 1879a, 1880). To delineate the geometry of the cone of depression and the radius of influence, he installed several observation wells, both perpendicular and parallel to the estimated flow direction of groundwater (Fig. 3). For this purpose, he mostly used Abyssinian wells ("Norton tubes"), sturdy prefabricated well tubes, usually of $50 \mathrm{~mm}$ inner diameter, which could be rammed into the ground and recovered - if necessary - afterwards. They were spaced more closely near to the well and further apart from it (Fig. 3). He also insisted on installing observation wells outside of the radius of influence to study the influence of natural variations of the groundwater levels, e.g., the ones caused by varying river water levels. By default, not only the drawdown phases for different pumping rates (Fig. 3) but also the recovery phase was observed (Thiem, 1876b). Another regular procedure was measuring the groundwater temperature during the test and taking water samples for later analysis. Already in Strassburg 1874/5 he used a "Locomobile mit Centrifugalpumpe“, a submerged centrifugal pump driven by an external steam engine (Thiem, 1876b). The drive shaft of the pump was probably connected to the engine via a belt, like a primitive drive shaft pump.

Adolf Thiem used one procedure, which is not common anymore: he increased the depth of the pumping well during the test to find productive zones, as he had realized early on that thin layers of high conductivity provide a disproportional yield of water. He was also probably the first to notice - and quantify - the difference between horizontal and vertical hydraulic conductivity. From the results of his pumping test in Strassburg, he determined a value of eight for the ratio of horizontal to vertical conductivity (Thiem, 1876b). This is remarkably similar to the default value of ten recommended in most textbooks today. During his exploration of the hydrogeology around Leipzig, Thiem realized the concept of multi-aquifer systems, i.e. the presence of several aquifers stacked on top of each other, separated by aquitards (Thiem, 1881a). He referred to these individual aquifers as "Grundwasseretagen“ (groundwater floors/levels). 


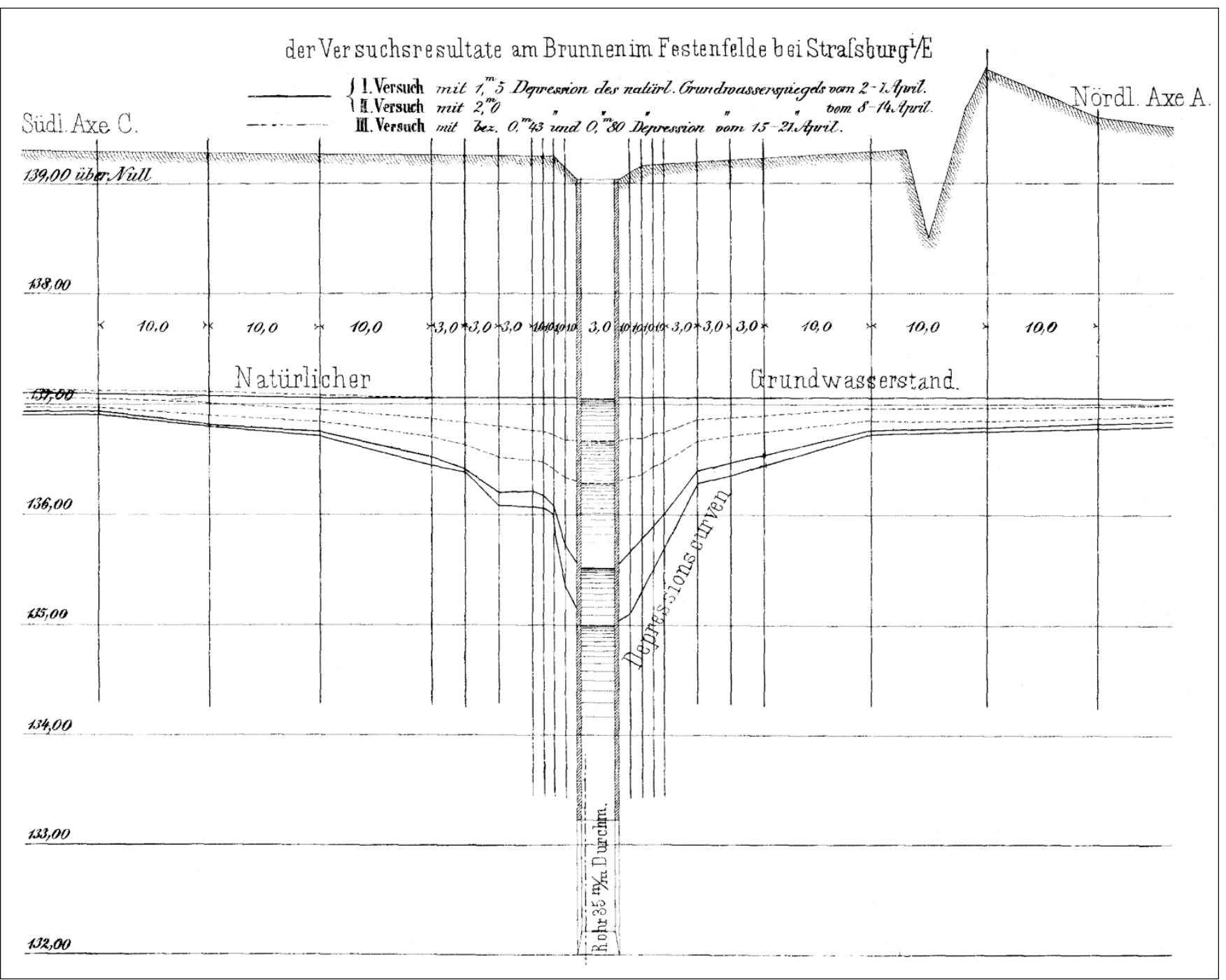

Figure 3: Sketch of the cones of depression for different flow rates obtained during pumping tests in Festenfeld near Strassburg/Alsace. The vertical black lines are the logarithmically (10 m, $3 \mathrm{~m}, 1 \mathrm{~m}$ spacing) arranged observation wells (Thiem, 1876b). Translation: Natürlicher Grundwasserstand = natural groundwater level, Rohr = well diameter: 35 mm, Depressionskurven $=$ pumping level curves, Versuch $=$ Test, Versuchsresultate $=$ test results, über Null $=$ above (French) sea level, Südl./Nördl. Axe = southern/northern axis. 
237 well-known Darcy-Weisbach equation (Eq. 3). Interestingly, Dupuit (1863) references his previous work as the source for the 238 velocity term, and Thiem (1870) calls it a "well-known equation" without citing any reference. Both thus ignore the 239 contribution by Julius Weisbach (1845).

242 with

$243 f_{\mathrm{D}}=\quad$ Darcy friction coefficient

$244 L_{\mathrm{B}} \quad=\quad$ length of borehole $(\mathrm{L})$

$245 r_{\mathrm{b}}=\quad$ radius of casing/screen $(\mathrm{L})$

$246 \mathrm{~g}=\quad$ acceleration of gravity $\left(\mathrm{L} / \mathrm{T}^{2}\right)$

Dupuit (1863) realized that he could use the velocity term to investigate the relative influence of pipe flow on well hydraulics.

249 He retroactively studied two wells in Grenelle and Passy, both near Paris. Again, Thiem $(1870,1879)$ converted Dupuit's 250 theoretical approach into a practical tool, the step-discharge test, which is still being used today. Therefore, he simplified 251 Equation 3 to

$$
H-h=K_{\mathrm{aq}} \cdot+k_{w} \cdot Q^{2}
$$

254 with

$255 H=$ head in well at zero flow [L]

$256 h=$ head in well while pumping (steady state) $[\mathrm{L}]$

$257 Q \quad=\quad$ pumping rate $\left[\mathrm{L}^{3} / \mathrm{T}\right]$

$258 K_{\mathrm{aq}} \quad=\quad$ hydraulic conductivity $[\mathrm{L} / \mathrm{T}]$

$259 k_{\mathrm{w}} \quad=\quad$ well loss coefficient $\left[\mathrm{T}^{2} / \mathrm{L}^{5}\right]$

261 This equation is still the main model to interpret step-discharge tests today. In his pump tests, Thiem plotted the drawdown s 262 as a function of different pumping rates Q and could identify the presence and quantify the contribution of the velocity term, 263 or in other words, the non-linear laminar and turbulent losses of the well itself (Houben, 2015a, b). If the s-Q pairs plotted on 264 a straight line, the flow was laminar and the velocity term negligible. Any deviations from a straight line could then be 265 attributed to additional well losses and quantified. Therefore, Thiem usually employed several pumping rates during his tests, 266 plotted the resulting drawdown curves and evaluated the contribution of non-laminar flow (e.g. Thiem, 1876a,b, 1879, 1880). 
Adolf Thiem realized that removing fines from the aquifer at high pumping rates can improve its hydraulic conductivity and thereby discovered the principle of well development (Thiem, 1875). In some cases, he took this to the limit and beyond. In the course of a pumping test in Strassburg/Alsace, the highest pumping rate of 136 l/s (490 m³/h) induced such a high degree of suffusion that the ground around the well subsided, and the well tubing was deformed (Thiem, 1875).

The method for pumping test evaluation after Adolf Thiem (1870) remained one of the most important hydrogeological tools for several decades. It was intensively discussed and applied in the USA (Wenzel, 1932, 1933, 1936, 1942; Meinzer, 1934), which can be traced back to the good contacts of Günther Thiem to the leading USGS hydrogeologist of its times, Oscar Meinzer (see section 4). The Dupuit-Thiem method was not without flaws: as a steady state method, it commonly required long times until the drawdown had become stable and needed two observation wells. The transient method by Theis (1935), which does not require steady drawdown and can do with one observation well, was the first serious challenger but remained problematic due to the use of type curves, which was both tedious and a bit subjective. Only its later simplification by Cooper und Jacob (1947) relegated the Dupuit-Thiem method to the second place.

Nevertheless, the Dupuit-Thiem equation can still be found in many textbooks (e.g. Batu, 1998; Kruseman and de Ridder, 2000; Bear, 2007; Kresic, 2007; Kasenow, 2010). Due to its geometrical set-up and simple mathematics, it is often used to teach students how to derive analytical models for groundwater flow (e.g. Hendriks, 2010). It is still helpful for the design of water wells and the planning of construction dewatering (Houben 2015a,b). For pumping tests, it has become a niche method when steady-state pumping test data are available (Misstear, 2001). The Dupuit-Thiem equation forms the basis for several later analytical models, including the old but still commonly used Forchheimer (1901) model, which describes the contribution of non-linear flow processes in the flow towards wells (Houben, 2015a,b). The Forchheimer equation consists of two terms; the first is the Dupuit-Thiem equation, which describes the linear laminar losses. The second term describes the non-linear laminar losses. Until today, the Dupuit-Thiem equation is used as a base-case for validation or as quality control for more advanced analytical models (see Tügel et al., 2016 for examples). Despite its simplicity and biblical age of 150 years, to this day, the Dupuit-Thiem equation is still an important method for groundwater professionals worldwide.

Prior to the full development of vertical wells, many hydrologists used backfilled drainage trenches instead, which could be of substantial length and depth (Houben, 2019). While working for the water supply of Winterthur, Switzerland, with Heinrich Gruner, Adolf Thiem considered such an option (Thiem, 1870). Therefore, he adapted his equation for well flow to a linear sink. Despite its simplicity, it only considered the height of the water table from the constant-head boundary to the drain in a 2D projection (Thiem, 1870). This was probably the first model for horizontal wells. 


\subsection{Contributions to well design}

The first pumping wells Thiem had used were shaft wells of large diameter, e.g. in Strassburg. They were difficult and expensive to build and often displayed poor performance. He realized that he could overcome these problems by developing the concept of the Norton wells (Abyssinian wells) further, which he had used as observation wells during his pump tests. In 1881-83, for the water works of Naunhof (Leipzig), he increased their diameter to $150 \mathrm{~mm}$, which still allowed them to be rammed into the subsurface. At first, he tried to emulate the shaft wells by installing so-called "Ringbrunnen" (ring wells), a central collector shaft surrounded by up to 20 individual rammed vertical wells, aligned on a circle with a radius of $10 \mathrm{~m}$ from the shaft (Engemann, 1989). The vertical wells were drilled first and then partially excavated down to the depth of the pipeline towards the central collector (Fig. 4). The latter still proved to be a difficult and expensive construction, and the many wells tended to interfere with each other. The Ringbrunnen were operated until 1926 (Engemann, 1989).

Later, he installed vertical well galleries, connected to a central siphon pipeline. This concept proved to be much more useful and cost-effective and became the standard. However, the vertical wells caused a lot of trouble due to corrosion, sand intake and incrustations, which often led to their complete failure to deliver water after only a few years. Thiem even equipped his wells with a noose, attached to the bottom, which could be used to pull out the whole well (Fig. 5). Later, a detachable screen was tried (Thiem, 1925). Thiem introduced cast iron as a material for screen and casing, which was more corrosion-resistant than the forged iron used before. Since the slots in the cast or forged iron screens were - due to technical reasons - quite wide (often up to $1 \mathrm{~cm}$ ), sand control was a critical problem. Many wells filled with sand eroded from the aquifer quite quickly. The solution used by Thiem was to wrap fine metal meshes around the screens, which, however, were prone to blockage by the very fines they were supposed to retain and by corrosion and incrustations. Due to their small diameter and the described clogging processes, the yield of the early Thiem wells was quite small, often in the range of a few cubic meters per hour. Therefore, Thiem had to install 225 of them for the first well field of Leipzig in 1883 and 300 for a later one (1907) in the same town (Thiem, 1925). Thiem kept tinkering with the well design, e.g. by simplifying the design (Fig. 5), increasing the diameter to $150 \mathrm{~mm}$ (1907 in Leipzig), installing rubber seals and introducing copper pipes, which were lighter, easier to manufacture and much more corrosion-resistant, although more expensive. For the Nuremberg water works, the tedious and problematic metal meshes were replaced by an artificial gravel pack, a technique that had already been used for horizontal drains (Thiem, 1879; Houben, 2019). In Nuremberg, Thiem (1879) proposed a gravel pack of four layers with gradually increasing grain size towards the well $(2,4,8,15 \mathrm{~mm})$. The well itself was made from perforated brickwork. 

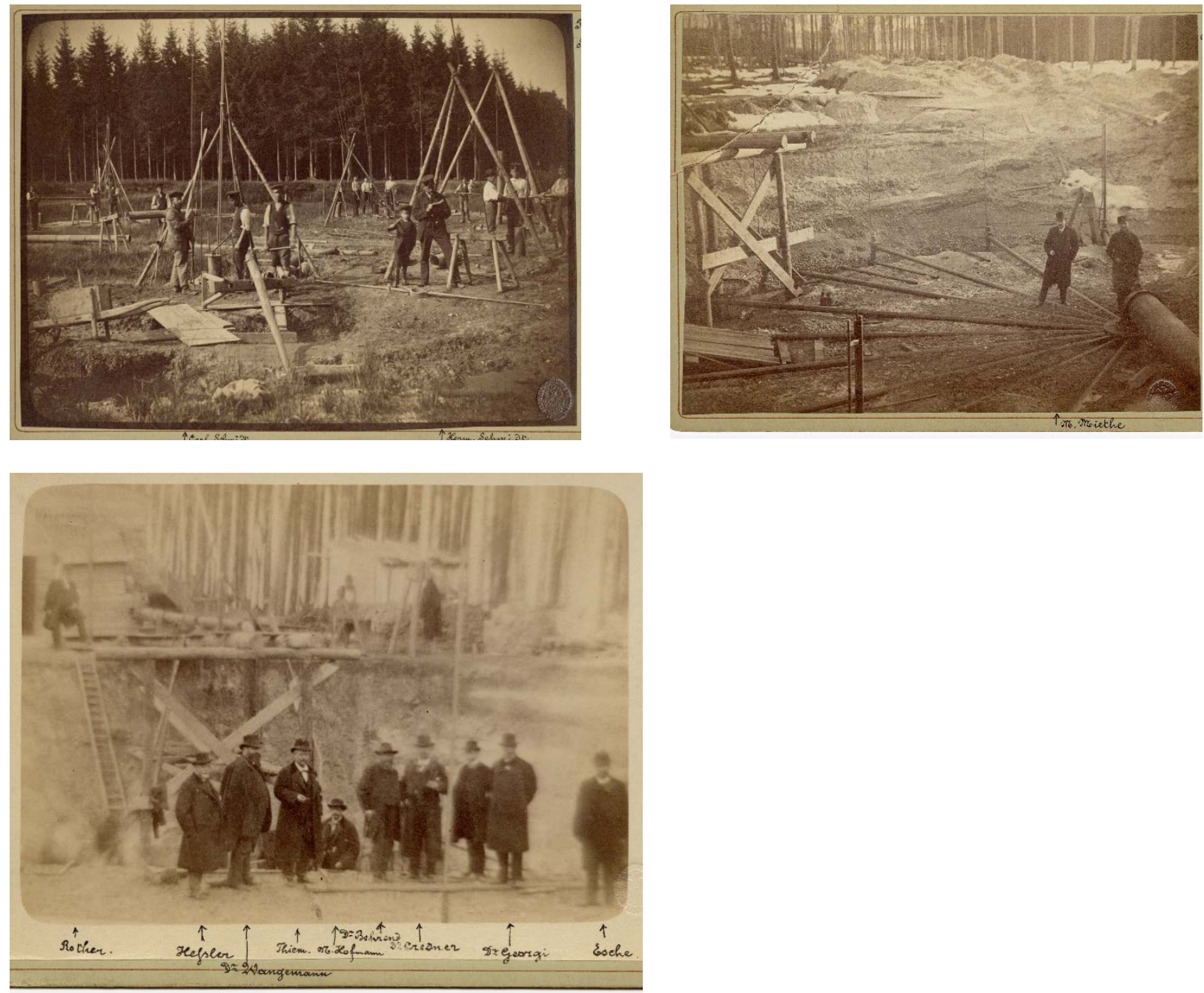

Figure 4: Construction of a "Ringbrunnen" at Leipzig-Naunhof, around 1887. Upper left: drilling of vertical wells, upper right: view of the radial pipelines connecting the vertical wells (visible at the end) to the central collector shaft, lower left: Adolf Thiem visiting the construction site (third from left, lower row). Also present is Prof. Credner, head of the Saxonian Geological Survey and Max Rother (left), one of Thiem's pupils (Photos: Stadtarchiv Leipzig). 


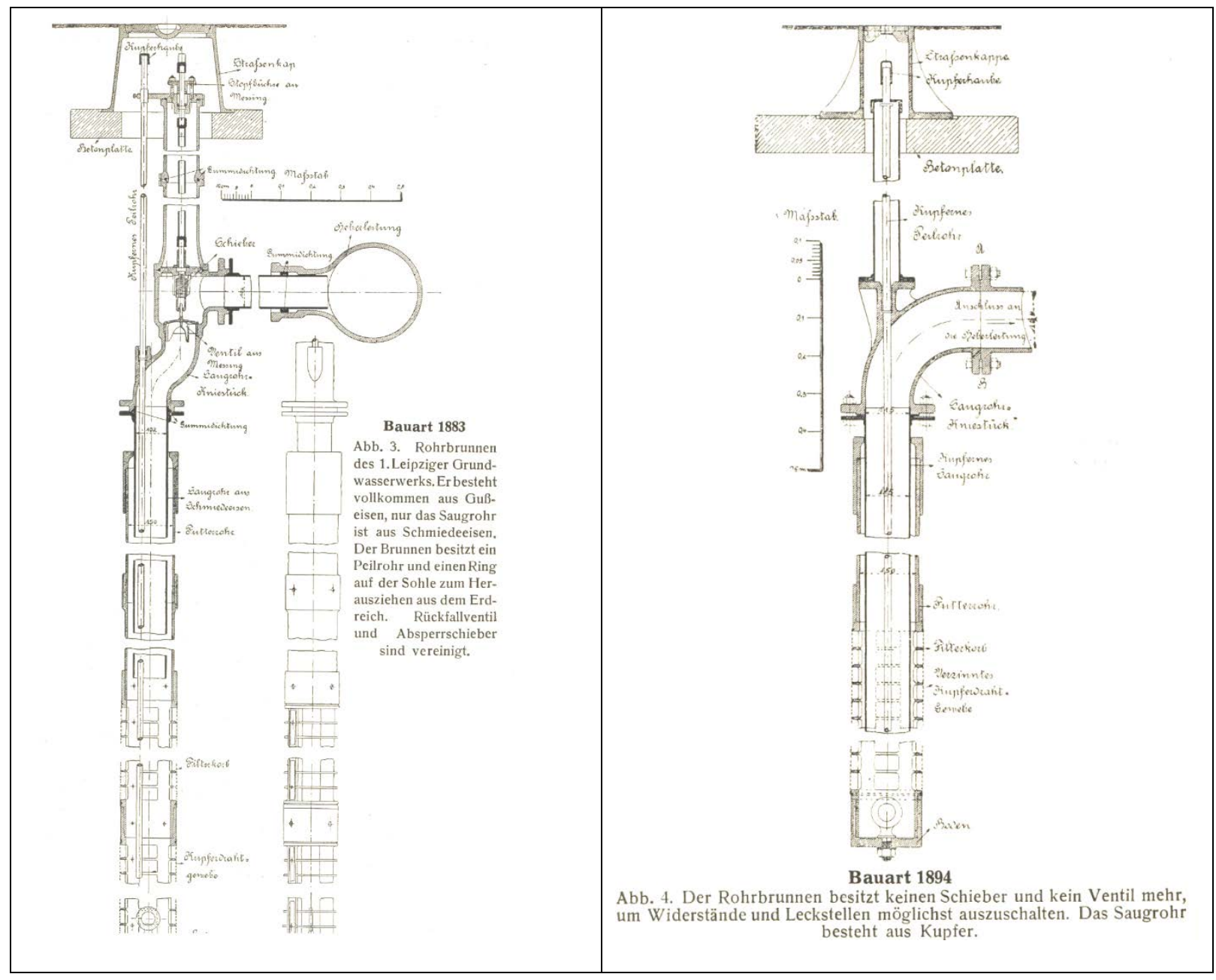

Figure 5: Well designs by Adolf Thiem used in Leipzig. Left: first design from 1883, cast iron screen, riser pipe from wrought iron; right: simplified design from 1894, backflow valve omitted, suction pipe now made of copper (Thiem, 1925).

Thiem also found time to study the flow of groundwater towards wells under laboratory conditions. In 1879 and 1882, Gustav Oesten had presented sandtank experiments on the groundwater flow to vertical, partially penetrating wells installed at two different depths in a square box (Oesten, 1879a, 1882a,b,c). Using colour tracers, he correctly observed that the highest flow velocities occurred around the screen. For a short screen installed at shallow depth, he found that coloured water from the bottom of the aquifer did not flow to the well (Oesten, 1882a). He thus postulated an interface separating a pumping-affected from a not affected area. Only a deeper placement of the screen induced flow from below. Adolf Thiem was very unhappy with this and stated in his rebuttal that his previous theoretical work had already clarified how water should flow around a well (Thiem, 1879d, 1882). However, he still felt obliged to perform his own sandtank experiments, which he called “demonstratio 
ad oculos" (Latin for "demonstration to the eyes"). At first, he used a square box but later a wedge-shaped sand body to simulate the convergent flow towards the well. The main objection of Thiem on the experiment of Oesten (1882a) was that Mr Oesten infiltrated water through a small trench at the surface of the box. As this did not represent the reality of flow to wells, Thiem allowed water to be infiltrated from one side over the entire thickness of the sand and the water level in this reservoir was kept constant by an overflow (basically a constant head boundary). The well was simulated by a little sieve body from which water was extracted. The images indicate that the bottom of the well was probably not closed. The well screen only covered the uppermost third of the saturated aquifer thickness. The flow paths were visualized by injecting small volumes of coloured water at different depths at the inflow side. This conclusively showed that water from below the screened interval also entered the well, inducing a vertical flow component close to the well and elevated inflow rates at both the top and the bottom of the screen. Thus, Thiem had conclusively demonstrated the flow field around a partially penetrating well. Mr. Oesten responded to the rebuttal (Oesten, 1882b), claiming rather unconvincingly that Thiem had not sufficiently considered the influence of capillarity, but the case was settled.

Unbeknownst to many well designers, Adolf Thiem defined one of the most critical and most criticized values, the maximum permissible entrance velocity. Many textbooks and international standards on well design cite a value of $0.03 \mathrm{~m} / \mathrm{s}(0.1 \mathrm{ft} / \mathrm{s})$, e.g. Campbell and Lehr (1973), Driscoll (1986), Sterrett (2007). Keeping the entrance velocity below this value is said to curb head losses, maintain fully laminar flow conditions, prevent suffusion of sand particles, minimize incrustation build-up and even to control corrosion. The value is sometimes attributed to Bennison (1947), who, however, presented neither theoretical concepts nor experimental or field data to back up his claim. It is very likely that this value goes back to experiments executed by Adolph Thiem, while he was designing wells and their gravel packs for the Nuremberg waterworks (Thiem, 1879). Thiem instinctively understood that the flow velocity of groundwater is the critical parameter that controls particle mobilisation and thus sand intake. Therefore, he investigated the minimum vertical flow velocity required to keep grains of different diameters in suspension. At velocities below, the grains would not be transported. For sand grains up to a grain diameter of $0.25 \mathrm{~mm}$ he obtained maximum flow velocities under which no transport would take place of $0.028 \mathrm{~m} / \mathrm{s}$, which is basically the recommended value above. The value found its way into the influential German textbooks by Smreker (1914) and Thiem's pupil Emil Prinz (1919) and the monograph by G. Thiem (1928). It is quite probable that US hydrologists became aware of this value from the German literature and through personal exchanges between Oscar Meinzer of the USGS and Günther Thiem (see below) and adopted it without further questioning.

For the water supply of the town of Greifswald, located at the German Baltic Coast, Adolf Thiem built a rather unusual construction in 1890 to extract groundwater. He had found an artesian aquifer of $6 \mathrm{~m}$ thickness under a confining layer of $5 \mathrm{~m}$ of glacial till (Houben, 2019). Instead of wells, he had a trench of $9 \mathrm{~m}$ depth and $450 \mathrm{~m}$ length constructed, equipped with two strings of perforated stoneware tubes of $500 \mathrm{~mm}$ diameter each, installed at different depths and then backfilled. He also had 
an impervious underground cut-off wall installed to impound the groundwater, allowing it to flow towards the town by gravity alone. Unfortunately, this most likely very expensive construction never lived up to the expectations. The yield was very low at $10.8 \mathrm{~m}^{3} / \mathrm{h}$ and soon had to be augmented by additional vertical wells.

\subsection{Development of tracer test methods}

Although reports on - sometimes involuntary - tracer experiments in karst aquifers predate the $19^{\text {th }}$ century, Adolf Thiem played a crucial role in developing tracer experiments into a scientific instrument, especially for porous aquifers (Thiem, 1887, 1888). His first field tests were done in 1886 in the towns of Greifswald and Stralsund, located at the Baltic Coast of Germany. He dissolved 75 to $100 \mathrm{~kg}$ of table salt $(\mathrm{NaCl})$ in water and measured the breakthrough curves in several observation wells (Thiem, 1888). Therefore, the chloride concentrations were determined via titration with silver nitrate, using potassium chromate as an indicator. During a tracer test in Plauen (Saxony), he observed five to six tracer peaks, which he attributed to the heterogeneity of the aquifer. To understand the fundamental processes of tracer migration Thiem (1888) performed laboratory experiments using a sand column of $4 \mathrm{~m}$ length. Based on his experiences, Thiem (1888) was the first to postulate fundamental requirements for tracer chemicals: (1) non-reactive, (2) non-toxic, (3) cheap and (4) easy and quantitative analysis.

\subsection{Equipotential and hydrogeological maps}

During his work in Augsburg with Gruner, Adolf Thiem made extensive use of Norton (or Abyssinian) wells, small but thickwalled pipe screens that could be rammed into the ground, to measure groundwater levels. Since they also determined the ground elevation of the observation wells, they were able to construct one of the world's earliest isopotential maps in 1873 (Mommsen, 1962; Dassargues et al., 2021). Strangely enough, Thiem considered the map produced for a later project in Strassburg, Alsace (now Strasbourg, France) as his first isopotential map, probably because he published a detailed account of this study in the Journal für Gasbeleuchtung und Wasserversorgung (Thiem, 1876b), which was widely received and acclaimed. Figure 6 shows a typical example of Thiem's clear graphical style, showing equipotentials based on observation wells, time series of groundwater levels and cross-sections showing aquifer thickness and water table.

Thiem immediately realized the influence of the water level of the neighbouring river Rhine on groundwater levels and thus constructed two equipotential maps, one for high and one for low river stages (Thiem, 1878). Due to its importance, the original drawing of the equipotential map was donated to the German Museum (Deutsches Museum) in Munich (Thiem, 1929q, 1941a), the most important technical collection of Germany. Unfortunately, it seems to have been lost during the war, as a request for it with the museum archive in 2020 by the authors led to no results. However, a copy is reproduced in some publications of Günther Thiem (1929q, 1931f, 1941a). 


\section{Sb̈hrenschichtempläno Des Grundowassers.}

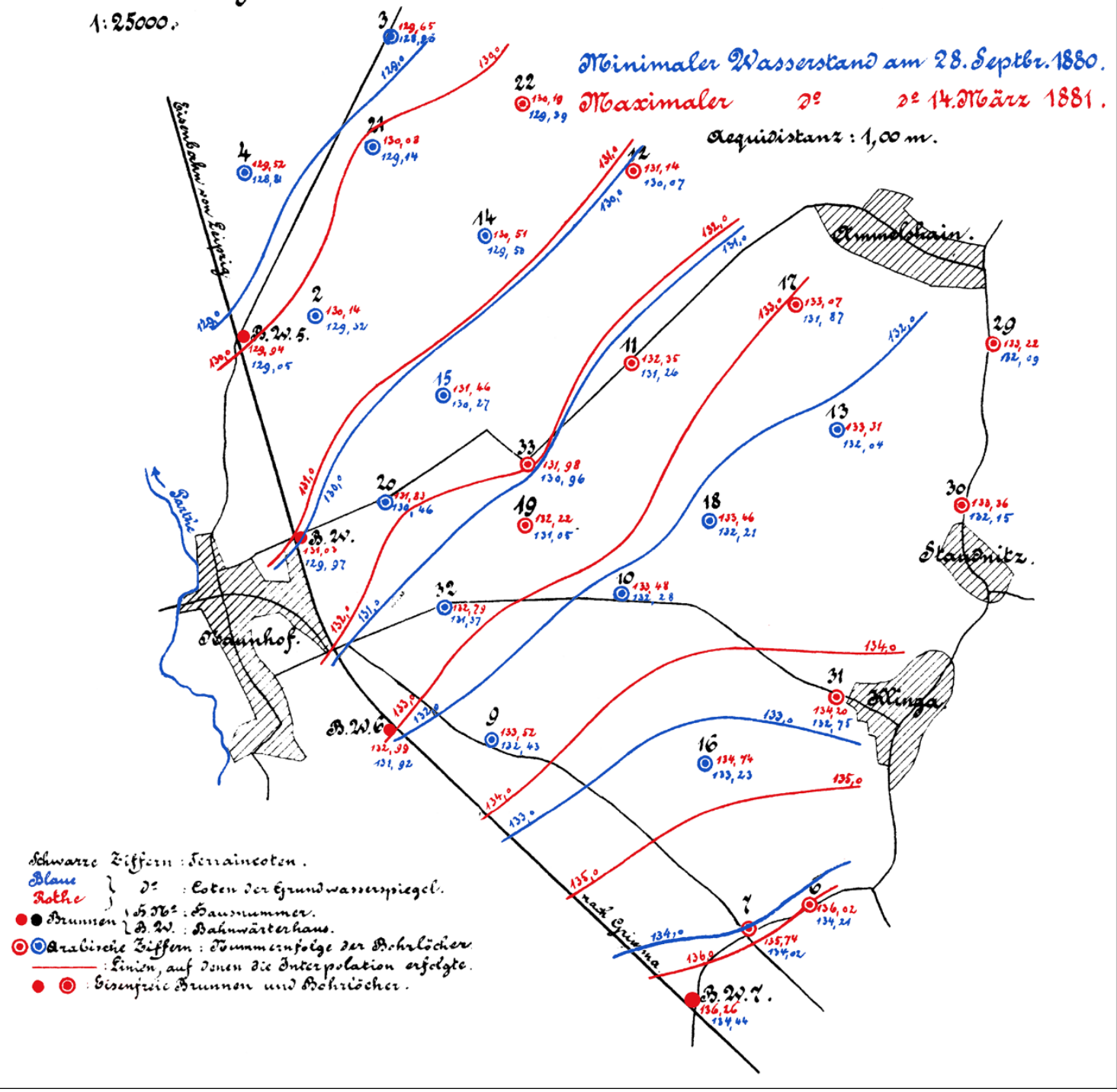

407

Figure 6: Isopotential map from the Leipzig-Naunhof study (Thiem, 1881). Blue isopotentials are from 1880, the red ones for 1881. Black dots and numbers show the observations wells. The straight black line in the west is a train track, and the shaded areas are villages.

Mainly due to the increasing demand for mineral resources, geological mapping became an important task in Germany during the second half of the $19^{\text {th }}$ century. The role of unconsolidated rocks as aquifers, however, was not overlooked. Adolf Thiem contributed a chapter "On the hydrology of the old river bed of the River Mulde near Naunhof" to the "Annotations on the Geological Map of the Kingdom of Saxony, section Naunhof”, Sheet 27 (near Leipzig), one of the first hydrogeological 

anathema to Thiem. It had been the geologist Prof. Hermann Credner (Fig. 4), head of the Saxonian Geological Survey, who pointed Thiem towards Naunhof, where the second water works for Leipzig was installed in 1887, the largest and most modern groundwater works of Europe at the time (Credner 1883; Thiem 1892a,b; Heinker 2005). Credner later supported Günther Thiem when he wanted to become a member of the German Geological Society in 1911.

\subsection{Artificial groundwater recharge}

Thiem quickly realized that not all aquifers were productive enough to satisfy the demand and that an augmentation via surface water might be useful (Thiem, 1898). Early on, he studied bank filtration, e.g. in Fürth in 1880 and for the town of Essen, and recommended using temperature as a tracer to distinguish ground and surface water (Thiem, 1898). He was also aware of the danger of colmation of the riverbed (Thiem, 1929q). For the water supply of Stralsund, Thiem had unsuccessfully proposed artificial groundwater recharge via drainage trenches (Thiem, 1888b), a concept already applied in Chemnitz in 1875, using trenches with an artificial sand bed (see discussion in Thiem, 1898; Houben, 2019). However, Thiem's Swedish pupil Johann Gustaf Richert (1857-1934) perfected the concept (Svensson, 2013). It was implemented for the first time in Göteborg in 1898. Richert published his experiences in a book in German (Richert, 1911), and the concept became quite popular in Germany after the turn of the century, especially in the Ruhr valley.

\subsection{Construction dewatering}

The construction of deep basements often requires working in the saturated zone and thus the control of groundwater. In the $19^{\text {th }}$ century, this problem was - if not avoided altogether - tackled by encapsulating the construction site and sealing it off from the surrounding groundwater, e.g. by ramming sheet piles, injecting cement or freezing parts of the aquifer. These procedures were technically demanding, costly and not always successful. Adolf Thiem realized that dewatering by verticals wells was a viable alternative since the well type he had developed could be installed cheaply and quickly, and his equations allowed him to dimension the dewatering scheme. In 1886, Thiem applied this concept, using a shaft well, for the first time in the construction of the Leipzig water supply in Naunhof (Prinz, 1907; Thiem, 1929q, 1931f). Therefore, Thiem can be considered one of the founding fathers of construction dewatering.

\subsection{Scientific feuds}

Thiem regularly attended conferences, e.g. those of the German Association of Water Professionals (DVGW), and was an avid contributor to the discussions (e.g. Thiem 1880b,c,d, 1885c, 188b,c). He did not shy away from voicing controversial opinions, which led to some prolonged scientific feuds.

The main opponent of Adolf Thiem was Oskar Smreker, born in 1854 on Castle Görzhof/Cilli, Austria-Hungary (now Celje, Slovenia), and died in Paris in 1935. He was a graduate of the Swiss Technical University (ETH) Zurich (1870-1874), where 
he, much later, in 1914, at the age of 60, received his $\mathrm{PhD}$ on a groundwater-related study (Smreker, 1914a). In 1876, he was hired by Heinrich Gruner in Regensburg as a replacement for A. Thiem, after Gruner and Thiem had parted ways, but he was sacked in 1877 (Mommsen, 1962). After several years as an engineer in Germany and Italy, Smreker founded a successful company in Mannheim, Germany, in 1882 that designed and built many groundwater supply systems in Germany and abroad. Smreker published several papers (Smreker, 1878, 1879, 1881, 1883, 1907), criticising both the work of Darcy (1856) and Thiem (1870, 1876b). He doubted the validity of the Darcy law - and the Dupuit-Thiem equation deducted from it - due to the supposed ignorance of the increase of velocity around a well. He even formulated his own non-linear law of groundwater movement and dared to use the results of Thiem's pumping tests from Strassburg to test it (Smreker, 1878). Adolf Thiem responded by citing ample literature based on both field and experimental data, which showed the validity of Darcy's law for practically all applications (Thiem, 1880).

Even after Thiem had died in 1908, Smreker would not relent. In his 1914 PhD thesis, several papers, and his textbook, Smreker still attacks the validity of Darcy’s law and upholds his alternative law (Smreker, 1914a,b, 1915a,b,c,d,e). He argued that “The Darcy law [...] fails completely when applied to the principle of groundwater abstraction, because the differences in velocities at the varying distances from the well are large“ (Smreker, 1914). Several prominent authors, including Max Rother (18551928), Adolf Thiem's last collaborator, felt obliged to publish a defence of the Darcy law. In the middle of the First World War (WW1) and shortly afterwards, a war of papers ensued across several journals and countries and arguments flew back (Brix, 1915; Rother, 1915, 1916a,b, 1919a,b, 1920; Lummert, 1916a,b, 1917a,b; Hocheder 1919) and forth (Smreker, 1915a,b,c,d,e,f, 1916a,b, 1918, 1919, 1920a,b,c), with Smreker receiving support from Hache (1919) and Henneberg (1919). Based on an extensive experimental comparison of equations using a Darcy permeameter, which he calls "Thiem apparatus", Krüger (1918) found the best fit using a modified Smreker equation. Other authors, like Weyrauch (1916), the Dutchman J. Versluys (1915, 1919), the Austrian-Hungarian J. Zavadil (1915) and Zunker (1920), tried to reconcile the approaches by investigating their limits. The latter also proposed a new equation based on experimental data. In 1919, the Journal für Gasbeleuchtung und Wasserversorgung apparently had enough of the discussion and tried to declare it finished (Anonymous 1919), to no avail (Rother 1920; Smreker 1920a,b,c). Adolf's successor, his son Günther Thiem participated only marginally in the feud (Thiem 1920i,l). He probably did not want to compromise his role as neutral editor of his journal (3.5). The feud lost steam in the early 1920s, after more than 40 years of struggle. Although several review papers had tried to declare Smreker's approach to be the correct one (Krüger 1918; Hache 1919), his struggle was in vain, and his equation fell into oblivion and is hardly cited today (Benedikt et al., 2018). Unbeknownst to most participants of the feud, Philipp Forchheimer, who was only marginally involved in it (Lummert 1916b), had already solved the problem in 1901 by proposing the law today known as Forchheimer law (Forchheimer 1901). It expands the Darcy law with a velocity term that can be used when flow velocities are high, e.g. in the vicinity of pumping wells. This fixes the deficiency of the Darcy law that Smreker had correctly identified. With low velocities, the Forchheimer equation reduces to the Darcy law, which thus remains valid for most situations. Smreker's feud with the Thiem School must have been quite bitter, as Smreker does not mention any hydraulic 
study of neither Adolf nor Günther Thiem in his otherwise excellent book (Smreker, 1914). This is quite unusual for a time when there were few published studies available, and Thiem had already been recognized as the founding father of hydrogeology in Germany.

Another hydrologist who got into trouble with Adolf Thiem was Gustav Oesten, a civil engineer and sub-director of the Berlin water works, later the author of an influential textbook on water supply that went through several editions (Oesten, 1904). He had published on the flow of groundwater to well screens based on sandtank experiments and interpreted them in a non-Darcian manner (Oesten, 1879a), which Thiem attacked in a quite sarcastic style (Thiem, 1879c; Oesten, 1879b). In 1882, Oesten published basically the same results in a different journal (Oesten, 1882a). Again, Thiem attacked his interpretations and even conducted experiments to show his point (Thiem, 1882; Oesten, 1882b). Details can be found in section 2.3.

\section{Günther Thiem}

\subsection{Biography}

Günther Thiem was born under the full name Ernst Gerhard Günther Thiem on October 11, 1875, in Regensburg, Bavaria, where his father was working with Heinrich Gruner (1833-1906) at that time (Fig. 7). After his father had relocated to Leipzig in 1886, he attended the renowned Thomasschule, Germany's oldest public school, founded in 1212, which was right next door to his childhood home in the Hillerstraße. He started his academic career in 1895, studying philosophy at the University of Leipzig. In 1896 he changed to civil engineering at the Königlich Technische Hochschule (Royal Technical University) in Stuttgart to follow the classes of Robert Weyrauch (1874-1924) and Otto Lueger (1843-1911), the last being Germany's leading expert on water supply and author of influential textbooks (Lueger, 1883, 1895). During the semester breaks, Günther worked in his father's consulting company. Lueger in his book "The water supply of towns" (Lueger, 1895), advocated for the use of springs and groundwater instead of surface water (Loehnert, 2013). However, some of his theoretical concepts were wrong; he followed the doctrine that groundwater under free water table conditions could not flow upwards (de Vries, 2006). In 1901 he reappeared in Leipzig with the title "Regierungs-Bauführer" (government building headman), which indicates that he intended to join the saxonian state administration. But this was not meant to be. Instead, he pursued his PhD in Stuttgart (section 3.2) and later took over the family consulting company after the rather sudden deaths of his older brother in 1907 and his father in 1908 (section 3.4).

He married Erna Carola Auguste Goelitz (1887-1976) in Marburg in 1909. They had three children, all born in Leipzig: Auguste Luisa Ingeborg (born 1911), Anna Else Erika (born 1913), and Karl Wolf Gunther (1917-2015), the latter a renowned art historian and head of the graphical collection of the state art gallery in Stuttgart (Hoffmann, 2017; Herfried Apel, pers. comm). After the death of Adolf Thiem, Günther's family moved into the old Thiem residence at Hillerstraße 9, where they stayed at least until 1949 (entry in the last available address book) but probably even longer until Günther's death and possibly 

the address book, she appears with the description "Privata”, indicating a rich widow who could live from her inherited means.
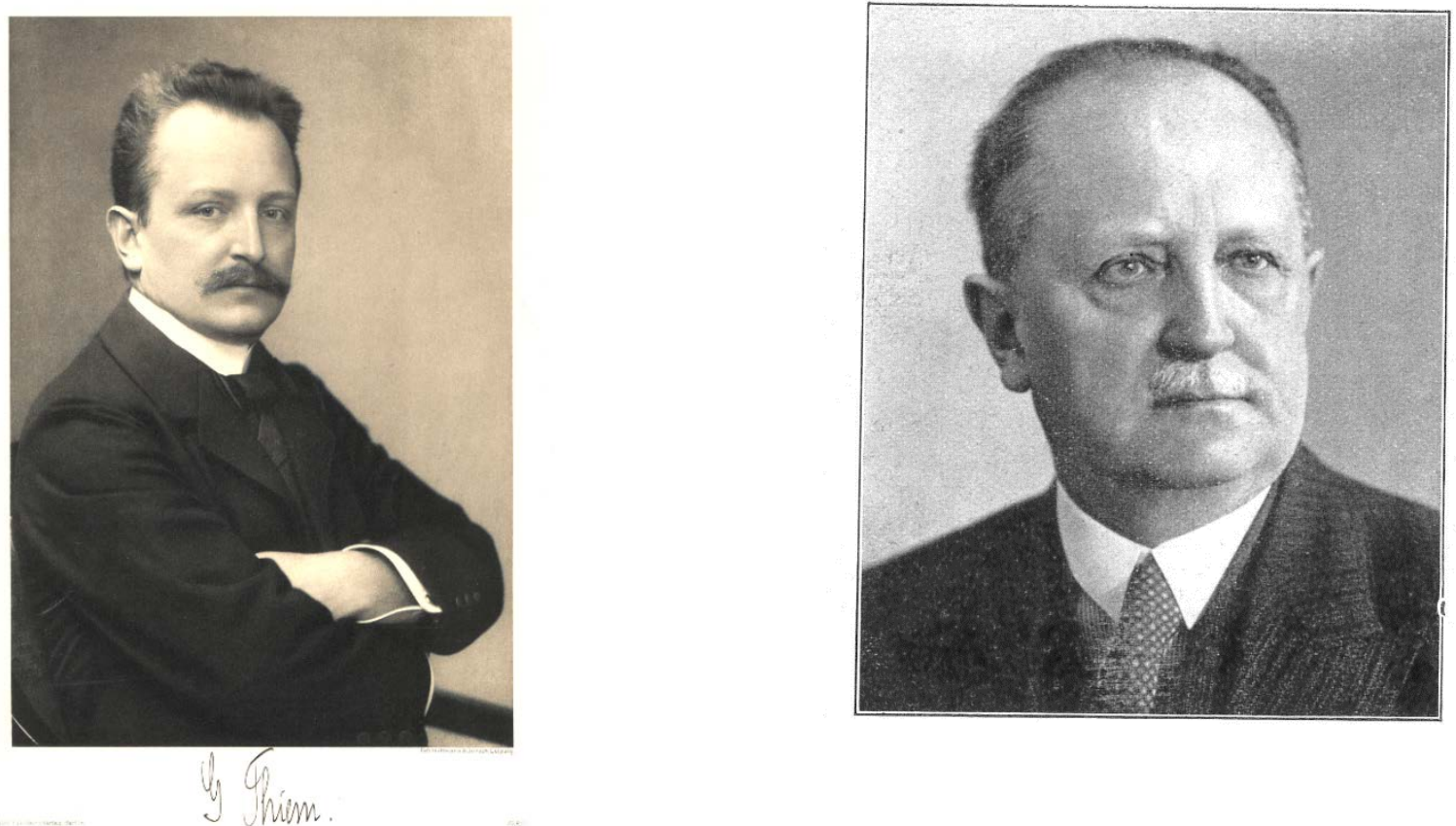

Figure 7: Photos of Günther Thiem. Left: around 1910 (Anonymous 1910), right around 1940 (Thiem, 1941a).

\subsection{Thiem (1906) PhD thesis}

Otto Lueger was also the advisor of Thiem's PhD thesis, which Günther dedicated to his father (Thiem, 1906). It was probably one of the first PhD studies solely dedicated to groundwater and was widely received in Germany and abroad. The PhD was remarkably short; 45 pages with 3 annexes, providing 10 borehole descriptions, 3 tables with results of calculations and 8 plans or cross-sections. The thesis had no formal reference list but referred in the text to publications of six authors (Darcy, A. Thiem, Slichter, Forchheimer, Dupuit, Lueger). Verbatim quotes were referenced from Slichter and Dupuit in respectively English and French. In the thesis, he presented the so-called $\varepsilon$-Verfahren (epsilon method). In essence, it was the Dupuit-Thiem pumptest analysis method for obtaining the hydraulic conductivity. However, instead of using a hydraulic conductivity K, he defined $\varepsilon$, which he called the unit capacity, as the product of the $\mathrm{K}$ and a unit cross-section normal to the groundwater flow. He derived and presented for unconfined and confined flow to wells, equations for $\varepsilon$, i.e., the Dupuit-Thiem equations. He then applied this method by performing ten pump tests to estimate the groundwater flow in a 6 km long section of the Iser River valley (now Jizera River) near its confluence with the Elbe River, close to the city of Altbunzlau (now Stará Boleslav, Czech Republic). The pumping tests were part of a study to develop groundwater resources for Prague, a project initiated by Adolf Thiem (Anonymous, 1903). The field investigation was executed in the first half of 1902. He showed that the Iser River is the 
receptor of the groundwater flow and that the higher the river bed is above the base of the unconfined aquifer and the closer one is to the river, the more vertical upward flow there is, which was in contradiction to the ideas of his advisor Lueger (1895).

The last chapter of Thiem's thesis is probably one of the first published extensive analyses of groundwater-surface water interaction. Thiem explained and presented in clear figures how equipotential lines are differently oriented towards a river dependent on gaining or losing river conditions (Fig. 8). But also he showed how during an infiltrating flood wave passing through the river the equipotential lines change of curvature near the river. Hence, he recognized and described the process of bank infiltration and storage. During 5 months, in support of studying groundwater-surface water interaction, he observed groundwater levels in piezometers at different distances from the river at the ten pump test locations. In one of the ten locations, he suffered data loss due to vandalism of his piezometer, apparently an issue of all times. By calculating the changing gradients, he observed, e.g. on March 25, 1902, that the high river water levels caused infiltrating conditions in the valley aquifer. Based on observed strongly changing gradients in the time frame of 48 hours, he concluded that groundwater level observations during at least one year are required to obtain an average gradient with which the groundwater flow to the river can be estimated. He also extensively discussed the temporal changes in groundwater-surface water interaction and sources of extracted water under the influence of seasonal groundwater level variations and the regime of a near-river located well. In designing the well field, Thiem aimed to avoid extracting low-quality surface water. Hence, Thiem developed an analytical equation to estimate the required distance between the river and the well, based on phreatic flow between two assumed fully penetrating canals (representing the river and the well). In the same chapter, he discussed the different infiltration and recharge characteristics of the study area; low on the loamy valley soils and high on the sandy terraces. Moreover, he described the strongly delayed response of rainfall on the groundwater levels, warning that the delay is generally well underestimated.

The proposed $\varepsilon$-Verfahren never became widely popular under this name, despite being discussed in detail in the book by Prinz (1919) in German but also in French by Imbeaux $(1921,1930)$. The approach Günther Thiem proposed was actually not novel as his father essentially already published in 1870 the derivation of the Dupuit-Thiem equation for estimating the hydraulic conductivity. Nevertheless, the $1906 \mathrm{PhD}$ thesis very clearly details and applies the method and is well cited, at least 521 times (Google Scholar, Oct 2020). Often the thesis is erroneously cited as the source of the Dupuit-Thiem model or Thiem equation (e.g. Wenzel, 1936; Meinzer and Wenzel, 1940), but this honour belongs to Adolf Thiem (1870), which has so far received only 30 citations. The clear exposition of the Dupuit-Thiem equation and Günther Thiem's support in transferring his method 

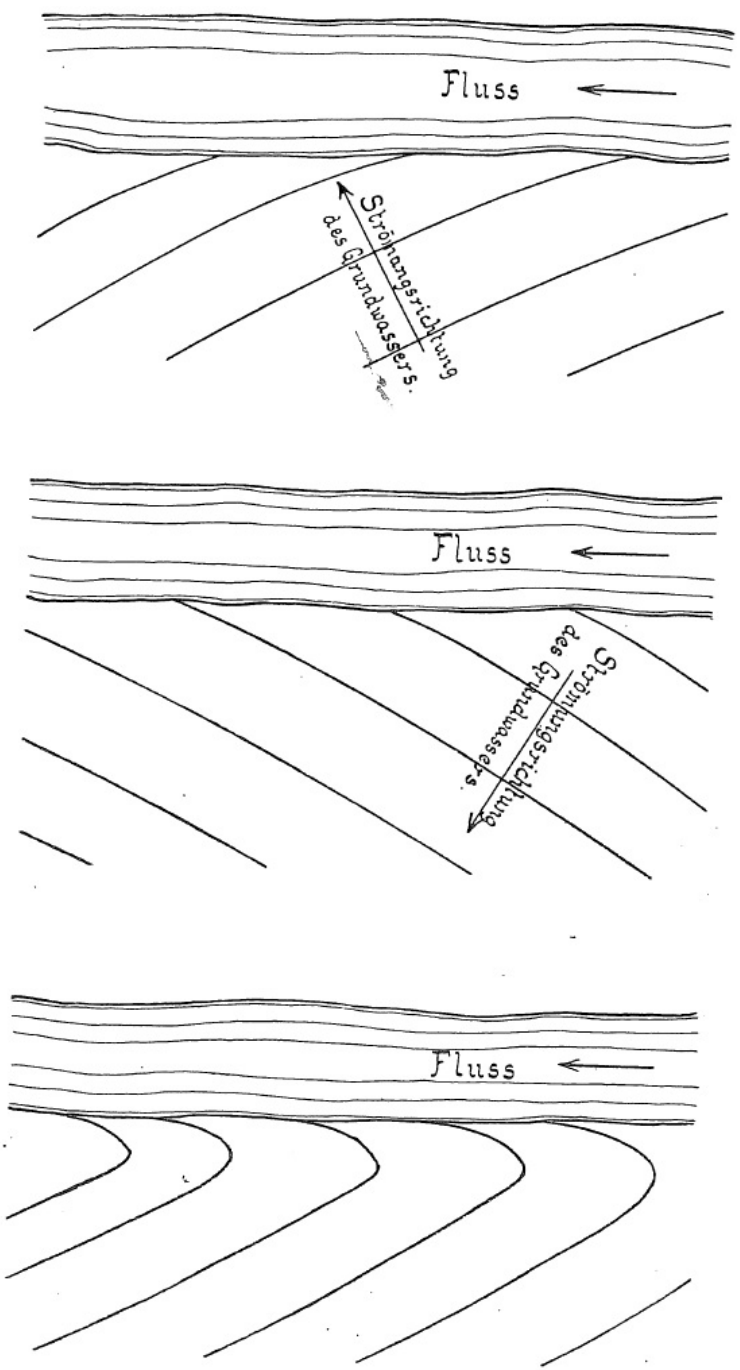

Figure 8: Groundwater-surface water interaction at Iser River near Prague, top: gaining conditions; middle: losing conditions; bottom: bank infiltration during river flood conditions (Thiem, 1906). Translation : Fluss = river, Strömungsrichtung des Grundwassers = flow direction of groundwater

\subsection{Work overseas}

567 After graduating in 1900, Günther Thiem went to the US and worked in New York for the Hering \& Fuller consulting company. 568 One of the founders was the famous civil engineer Rudolph Hering (1847-1923), member of the "Hall of Fame" of the 569 American Water Works Association and eponym of the "Rudolph Hering Medal“, awarded by the American Society of Civil 570 Engineers for outstanding contributions to environmental engineering. Being of German descent, Hering had been sent by his parents to Dresden to attend school and university. Whether he came into contact with Adolf Thiem during this period remains 
unclear. One of Günther Thiem's projects in the US was building the water supply for the city of Jersey, New Jersey. He also travelled to Egypt, India and Ceylon (Sri Lanka) during this time (Thiem 1915c, 1936c, 1955a). In 1903, he returned to Leipzig and became a junior partner in his father's company. While the bulk of the work there was in Germany, he was also involved in projects in Austria-Hungary, Switzerland and Russia (details see below).

\subsection{Consulting Engineer}

After the death of his older brother and father, Günther took over the consulting company in Leipzig in 1908, employing five to seven engineers and several technical staff (Anonymous 1910). In 1911, he moved the offices to Marschnerstraße 13, in 1915 to Plagwitzer Straße 9 and finally in 1939 to Plagwitzer Straße 7 (today Käthe-Kollwitz-Straße), which was basically in the same corner house as his home in Hillerstraße 9. All mentioned buildings survived the war with minor damage, were nicely refurbished after the reunification and still exist today (Fig. 9). Public water supply companies were his main clients. For them, he designed and supervised the construction of many water supply schemes in Germany and abroad (Table 2). Most of them were based on groundwater and a few on bank filtration, which he considered artificial groundwater (Thiem 1919k). He also served in the city council of Leipzig (1913-1918 and 1921-1922). In 1912 he was appointed as "Gerichtlicher Sachverständiger” (surveyor appointed by the court). During the First World War, he served in the German Army as field engineer and published papers on military aspects, e.g. the construction and drainage of trenches (Thiem, 1915a, 1916e, 1917e), field water supply (Thiem, 1917a, 1919c) and the disinfection of water (Thiem, 1916d, 1918a, 1918d, 1919c). For his efforts, he was awarded the Saxonian medal of war merit (Kriegsverdienstkreuz), a fact that is curiously never mentioned in any of his later biographies (Anonymous 1917).

After the war, he applied his skills in the growing field of lignite mining, which had major impacts on groundwater resources through the dewatering of the open-pit mines in central Germany and Bavaria (Thiem, 1920b,m, 1921c, 1922a,b, 1923d, 1924a,b, 1928e, 1929b,i, 1930b, 1935b, 1937d, 1938a, 1939e, 1940e, 1952). In his publications of this time, he introduced himself as "Montanhydrologe" (mining hydrologist) and tried to convince the mining engineers that geohydrology was an important contribution to their field. The industrial water supply also became important (Thiem, 1919k, 1920k, 1922e, 1924c,d,e,f 1929l, 1931e, 1935d,e, 1937a). Building on the work of his father, he was also an important contributor to the improvement of the design and construction of vertical wells (Thiem, 1911d, 1916b, 1917d, 1919f, 1920c,d,j, 1923c,f, 1924h, 1925a, 1928a,d, 1929f, 1936a, 1938d, 1941b, 1942, 1951b,c, 1953c,d). Similar to his father, he investigated hydraulic and economic aspects of pipeline networks (Thiem, 1910b, 1910h, 1912b,c, 1915d, 1918c, 1919b,d,e, 1920a, 1924c,e, 1931b,i,n, 1932a,d,e, 1938b, 1954) and their maintenance (Thiem, 1914b, 1929d). Water treatment, especially the removal of ferrous iron, was a side issue (Thiem, 1910i, 1914d, 1915b, 1924d, 1928c,f, 1929a, 1931m). He also designed and, unlike his father, patented technical equipment, amongst them a device to measure groundwater levels (Thiem, 1908), a detachable riser pipe (Thiem 1911d), a water meter (Thiem 1911e,f 1912a), a device for screened wells allowing the injection of chemical reactants to dissolve incrustations (Thiem, 1931d), an acid-proof coating for metal well screens (Thiem 1931j), a rubber pipe seal (Thiem 


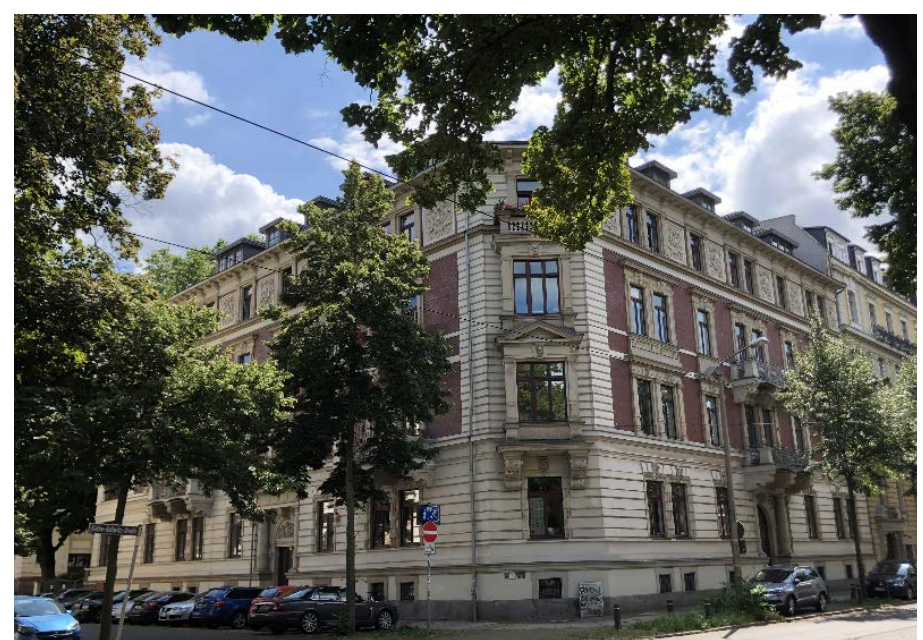
(Thiem, 1937c).

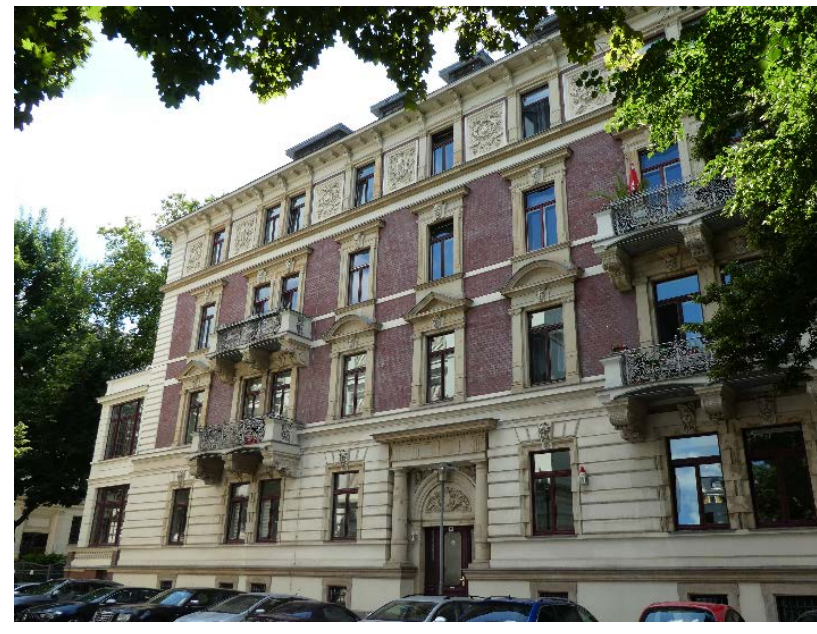

1933d), a check valve with the wonderfully German name "Rückschlagklappenventil" (Thiem, 1935b) and a gate valve

Figure 9: (left) Corner house Hillerstraße 9 (left) and Plagwitzer Straße 7 (right, today named Käthe-Kollwitz-Straße), Günther had his offices in Plagwitzer Straße 9 (yellow building to the right) since 1915 and finally in Plagwitzer Straße 7 since 1939, (right) Hillerstraße 9, the Thiem family residence: Adolf and his family lived there on the second floor since 1887, Günther took over in 1909 (Photos: Houben).

Due to his age, he did not serve in the Second World War (WW2) but contributed several short publications detailing the water supply for troops in the field, copying his work produced during WWI (Thiem, 1937b, 1940b).

Table 2: Main water supplies planned and built by Günther Thiem (English names in parentheses)

\begin{tabular}{|l|l|l|l|}
\hline Name of city & Name of city today & Comment & References \\
\hline $\begin{array}{l}\text { Prag (Prague), } \\
\text { Altbunzlau, Czech } \\
\text { Republic }\end{array}$ & Praha, Stará Boleslav & then Austria-Hungary & Thiem (1906) \\
\hline Landeshut & $\begin{array}{l}\text { Kamienna Góra, } \\
\text { Poland }\end{array}$ & then Germany & Thiem (1909b) \\
\hline Harburg & & today part of Hamburg & Thiem (1910a) \\
\hline Wilhelmsburg & & $\begin{array}{l}\text { today part of Hamburg } \\
\text { schemes }\end{array}$ & Thiem (1910c) \\
\hline Leipzig & & $\begin{array}{l}\text { Thiem } \\
1911 \text { a,b, 1912b, 1914c, }\end{array}$ \\
\hline
\end{tabular}




\begin{tabular}{|c|c|c|c|}
\hline & & & $\begin{array}{l}\text { 1915d, 1920g, 1922c, } \\
\text { 1935a,d, 1957) }\end{array}$ \\
\hline Czernowitz & Czernowice, Ukraine & then Romania & $\begin{array}{l}\text { Thiem (1910e, 1910f, } \\
\text { 1929c,n) }\end{array}$ \\
\hline Magdeburg & & & Thiem (1910g, 1921b) \\
\hline Mönchengladbach & & & Thiem (1911c) \\
\hline St. Petersburg, Russia & & & $\begin{array}{l}\text { Thiem } \quad \text { (1913b,c, } \\
\text { 1929k,m) }\end{array}$ \\
\hline Vaasa (Wasa), Finland & & then Russia & $\begin{array}{l}\text { Thiem (1913e), Juuti } \\
\text { and Katko (2006) }\end{array}$ \\
\hline Meerane & & & Thiem (1914d) \\
\hline Kempten & & & Thiem (1915e) \\
\hline Aue & & & Thiem (1916c, 1923a) \\
\hline Zeitz & & & Thiem (1919e, 1920f) \\
\hline Danzig & Gdansk, PL & & Thiem (1919a,h,j) \\
\hline Halle & & & $\begin{array}{l}\text { Thiem (1919i,l 1921a), } \\
\text { Winterer (1919) }\end{array}$ \\
\hline Mitau, Latvia & Jelgava & & Thiem (1929e,n,o) \\
\hline Posen, Poland & Poznan & & $\begin{array}{l}\text { Thiem and } \\
\text { Matakiewicz (1923) }\end{array}$ \\
\hline Zittau & & & Thiem (1929g,h,p) \\
\hline $\begin{array}{l}\text { Tampere } \\
\text { (Tammerfors), Finland }\end{array}$ & & & $\begin{array}{l}\text { Gagneur and Thiem } \\
(1928,1929)\end{array}$ \\
\hline Wolmsdorf & & & Thiem (1930b) \\
\hline Bautzen & & & Thiem (1931b,h,l) \\
\hline Saaz, CZ & Zatec & & Thiem (1932b,c) \\
\hline Reichenberg, CZ & Liberec & & $\begin{array}{l}\text { Thiem (1933a,d, } \\
\text { 1934a, 1939d) }\end{array}$ \\
\hline $\begin{array}{l}\text { St. Moritz, } \\
\text { Switzerland }\end{array}$ & & & $\begin{array}{l}\text { Thiem } \quad \text { (1933b,c, } \\
\text { 1934b,c) }\end{array}$ \\
\hline
\end{tabular}




\begin{tabular}{|l|l|l|l|}
\hline Samaden, CH & & & Thiem (1936b,d) \\
\hline Dessau & & & Thiem (1955b) \\
\hline
\end{tabular}

617

Other cities he worked for include Zwickau, Freiberg, Spremberg, Gera, Linz (Austria), and Suceava, Romania, then AustriaHungary (Pöpel 1956). In his study for Mönchengladbach, he lists the prices for several of his hydrogeological investigations, including drilling costs and their duration (Thiem 1911c). The investigations in Prague and Leipzig took about 200 days each and cost 51,000 and 30,000 German Mark. The study in Czernowitz took 67 days, while the one for Mönchengladbach required 150 days, both at the cost of about 15,000 Mark. To roughly convert these prices into Euro, one has to multiply them by 5.2 . During his work in Switzerland in the early 1930s, he briefly became technical director of the Hydrotechnik AG, Zurich (Thiem 1933c).

\subsection{Editor, publisher and author}

In 1914, Günther Thiem became the executive editor of the „Internationale Zeitschrift für Wasser-Versorgung“ (International Journal for Water Supply), founded by the „Internationaler Verband der Wassersachverständigen” (International Association of Water Experts), the first international journal exclusively dedicated to hydrology. The journal was published through his own publishing company “Technischer Verlag Dr.-Ing. Günther Thiem”. Rudolph Hering (USA), Édouard Imbeaux (France), Felice Poggi (Italy) and J.G. Richert (Sweden) acted as additional editors (Fig. 10). His contacts thus went further than the US (see Section 4) and, despite all political problems, included the French-speaking world, e.g. through Prof. Imbeaux, whom he calls “... a dear old friend” in the letter shown in Figure 11. Even in 1916, when the war between Germany and France was in its third year, Günther Thiem published a paper on the water supply for Nice, France (Thiem, 1916a). The friendship with Imbeaux outlasted the war, and as early as 1921, Imbeaux promoted the Thiem epsilon method in an article (Imbeaux, 1921). Contributions to the journal came from all over the world, including from leading US hydrologists of the time, such as Charles Slichter (Slichter, 1915). Günther also republished several of his father's older publications (A. Thiem, 1914, 1915, 1918, 1920).

Interestingly, the 1917 issue of the journal still mentions all original foreign editors, although Germany was at war with France and Italy (Hoefer von Heimhalt from Vienna and his former teacher Robert Weyrauch from Stuttgart had been added meanwhile). The journal was active throughout WW1, but only published articles in German. In 1918, Günther Thiem realized that the term "International” in both the journal title and the name of the association was awkward at a time of war and dropped it. The names of Hering, Imbeaux and Poggi disappeared as coeditors, while H. Peter from Zurich, Switzerland, was added. In mid-1919, the journal was renamed "Zeitschrift für Wasserversorgung und Abwasserkunde” (Journal for Water Supply and Wastewater Science). In 1920, he decided to give up the journal, and it was subsequently merged into the journal "Wasser und Gas”, which appeared until 1934, with Günther serving as associated editor. He also worked in the same position for the 
“Kalender für das Gas- und Wasserfach”, a yearbook for the gas and water field, which appeared between 1921 and 1938. After WW2, Günther Thiem did reappear as editor of a journal: from 1951 to 1956 he was listed as co-worker of the journal "Bohrtechnik, Brunnenbau (Drilling technique, well construction)”. Ironically, after his death in 1959, the East German government forgot to delete his now inactive publishing company from the public registry. Finally, in 2007, several years after the German reunification did the authorities finally delete it.

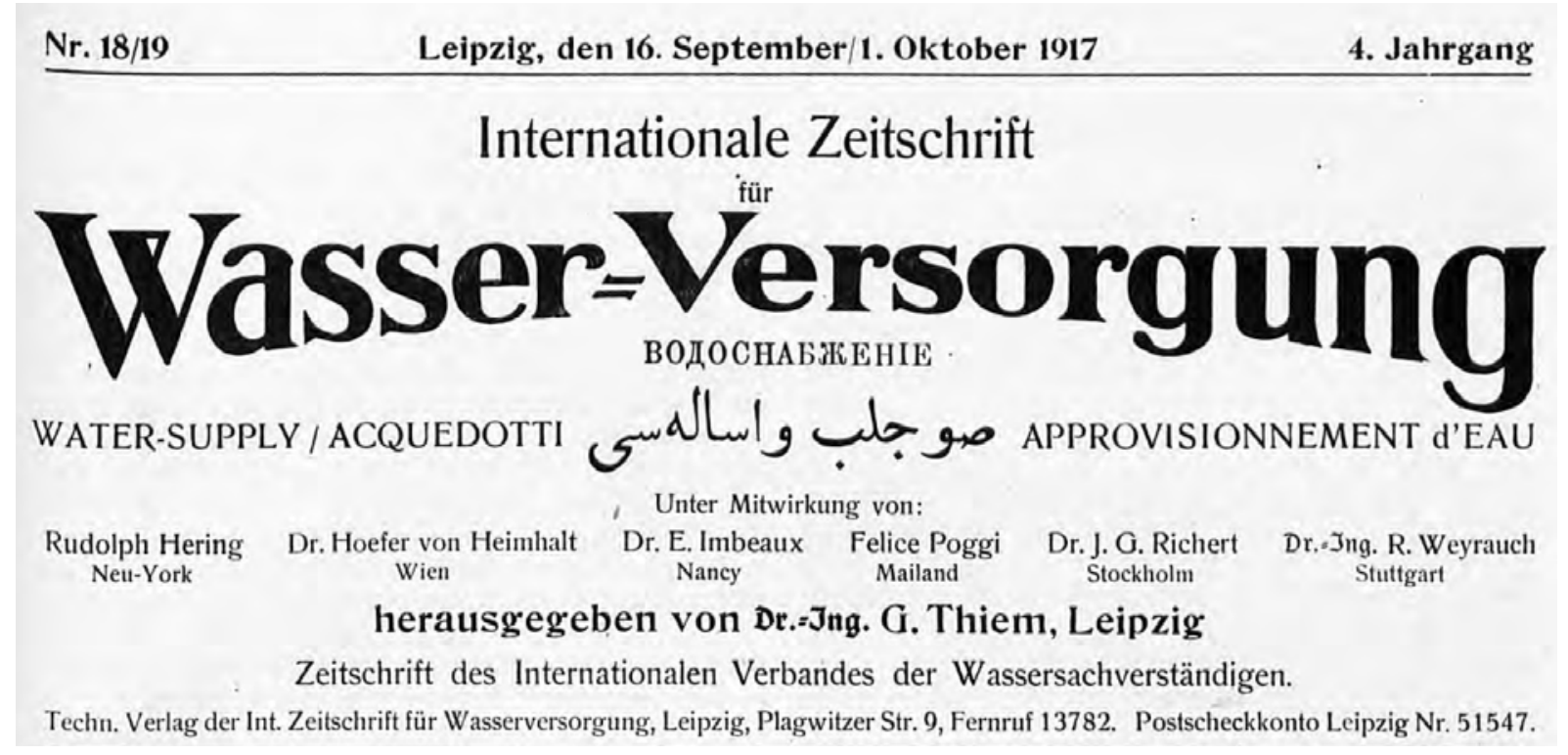

Figure 10: Header of the "Internationale Zeitschrift für Wasser-Versorgung” (1917), showing the international co-editors and the journal title in different languages.

Günther Thiem was a prolific author. He left a legacy of around 200 publications treating theoretical concepts, technical inventions, case studies from his consulting work and promoting the general benefit of groundwater. He repeatedly published papers or booklets that summarized the gained knowledge on hydrogeology (e.g. Thiem, 1907, 1909a, 1913d, 1914a, 1917b,c, 1918b,e, 1919g, 1920e,h, 1922d, 1923e, 1925b,c, 1926a, 1927a,b, 1928b, 1929j,l, 1930a,c, 1931a,f,g,k, 1939f, 1940d,f, 1941a, 1951a, 1953a,b, 1955c; Thiem and Gagneur, 1929). His interest in international hydrological affairs is evidenced by several review articles on foreign water supply schemes, stretching as far as the Soviet Union and Egypt (Thiem 1915c, 1916a, 1923b, 1924g, 1936c). Many of his publications appear in a series published by himself, called "Thiems Hydrologische Sammlung" (Thiem's Hydrological collection), a series of small booklets, which often are reprints of some of his papers published in Journals. He was also a great communicator whose oral explanations of by integrals supported hydrological calculations, were even understandable for lawyers (Grahmann, 1960). This was often necessary since the quantitative methods introduced by both Thiems were initially often met with scepticism. As late as the early $20^{\text {th }}$ century, a senior government official told Günther 
Thiem "Your whole hydrology is nonsense, I simply build well after well, until I obtain the desired quantity of water" (Thiem 1911c). Luckily, these random searches for groundwater, often "aided" by the use of the divining rod, were slowly overcome due to the persistent work and the publications by both Thiems. During his search for groundwater for the city of Bautzen, Günther actually hired two water diviners to compare their results to his drill holes, with less than convincing results for the divining rods (Thiem 193b,h,l).

\subsection{Honours}

Like his father's work, Günther's contributions to Leipzig and Prague's water supply were considered important enough to be shown at the world exhibition in Brussels 1910, where he was even awarded a silver medal (Stoffers, 1910). The occasions of his $60^{\text {th }}, 75^{\text {th }}$ and 80th birthdays in 1935 and 1955 were honoured by the publication of short biographies (Anonymous, 1935, 1950, 1955, 1956; Lang 1950; Paavel 1955; Herzner 1955). Although not of working class background, Thiem was also honoured by the East German communists, who took over in Leipzig after WW2. In December 1952, they awarded him the somewhat peculiar title "Verdienter Techniker des Volkes" (merited technician of the people), one of the first to receive this honour (Henneberg, 1952). In the same year, he was appointed Ehrensenator (honorary senator) of the Hochschule für Bauwesen (University of Construction) in Leipzig (Schöne, 1959). Not to be outdone, he also received prices from West Germany. In 1956, the German Association for Gas and Water (DVGW) awarded him their highest honorary price, the BunsenPettenkofer-Ehrentafel (Ehrentafel $=$ shield of honour, Anonymous 1956), and the Technical University of Stuttgart commemorated the $50^{\text {th }}$ anniversary of his PhD by awarding him the Golden PhD diploma (Pöpel 1956; Schöne, 1956). His death was mourned in both East and West Germany (Anonymous 1959a; Anonymous 1959b; Schöne 1959; Grahmann 1960).

\section{Günther Thiem and Oscar Edward Meinzer}

The work by Adolf Thiem had already been noted in US literature (e.g. King and Slichter, 1899), but it was Günther who popularized the Thiem methods abroad, especially in the US. Trying to understand the background to why generally in the US literature (Ritzi and Bobeck, 2008) the Dupuit-Thiem equation is called the Thiem method after Thiem (1906), and why it became so popular, we investigated the contacts between Günther Thiem and US scientists, especially Oscar Edward Meinzer.

C.V. Theis, former District Geologist and Division Scientist at the USGS Division of Ground Water from 1930 till his official 'retirement' in 1970, was interviewed by John Bredehoeft in 1985 (Theis, 1985; Bredehoeft, 2008). "CV” was at that time already 85 years old. Although he took time to respond, his mind was still sharp, and he remembered quite clearly (Bredehoeft, 2008). Bredehoeft asked CV about the pumping test in Grand Island, Nebraska, run by the USGS (Wenzel, 1932, 1933, 1936). Theis replied that Meinzer had gone to Europe to meet Günther Thiem, who had been using pumping tests for water supply, and "brought back the idea and to really try it out". He said "it was the only one at that time [in this country], ..., well, no, who was it that presumably made some sort of a pumping test in Pennsylvania?". He also related that "this was just before 
Hitler's time and Meinzer was sending back to Thiem various baskets of food because Thiem was having a hard time there”.

The food baskets were most likely sent after the war since Thiem was a successful businessman before it.

The Grand Island pumping test was planned in 1930 under the supervision of O.E. Meinzer, who was since 1912 Geologist in charge of the Division of Ground Water of the USGS. The measurements took place in summer 1931; results were described in short in Wenzel $(1932,1933)$ and fully documented in Wenzel $(1936)$. The goal of the two performed pumping tests was "to ascertain the accuracy of the Thiem method and to investigate the possibilities of determining specific yield by a pumping test" (Wenzel, 1936). The Wenzel 1932 and 1936 publications both have in their title "The Thiem method for determining permeability of water-bearing materials...” and described the method extensively. Meinzer (1932) also explained the method, it is likely that he presented the method already at a meeting of the Society of Economic Geologists in New York City, Dec. 29, 1928: "Mimeographed copies of the paper in abbreviated form had been sent to the members prior to the meeting. The paper has been revised and enlarged for the present publication” (Meinzer, 1932). Both Meinzer and Wenzel referred to A. Thiem, particularly the Thiem (1887) tracer test paper but not to the Thiem (1870) paper. However, Meinzer (1934) referenced also Adolf Thiem (1870): "He introduced field methods for making tests of the flow of ground water and applied the laws of flow in developing water supplies. Under his influence Germany became the leading country in supplying the cities with ground water. The results of his work appeared in a number of papers, the first in 1870”. Hence, we may assume that Meinzer was, since at least 1928, aware of the Thiem method based on Thiem (1906) and Thiem (1870). The Wenzel (1936) Water-Supply Paper 679A effectively established the Thiem (1906) method as a standard for permeability assessment of pumping tests and received broad uptake. In the acknowledgement of Wenzel (1936), Leland Wenzel thanks Günther Thiem for his criticism of the manuscript, which shows the existence of contacts between Thiem and the USGS at least during the 1930's.

It took between 66 and 30 years after respectively Thiem (1870) and Thiem (1906) until the Thiem type of pumping test was introduced and made popular in the US. Although Meinzer $(1925,1928)$ realized the importance of compressibility and elasticity of aquifers in the 1920's, the dominant groundwater flow theory was steady state and dictated by the Dupuit-Thiem model until Theis published his transient solution in 1935 (Theis, 1935; Deming, 2002). The slow acceptance of the Theis equation (in part by Meinzer) meant that by 1936 the USGS Water-Supply Paper 679-A still could widely introduce and make the Thiem method popular in the US.

To investigate in more detail the contacts between Günther Thiem and the USGS, we requested a search of the US National Archives through record group 57 of the U.S. Geological Survey. This resulted in Entry A1 593, "Correspondence and Other Records Relating to the International Committee on Underground Water, 1936 - 1946”, about 42 pages of relevant correspondence between Günther Thiem and Oscar Edward Meinzer dated between 1 December 1936 and 23 August 1940 (Thiem and Meinzer, 1936-1940). The correspondence consists of 17 letters from Thiem to Meinzer and one to Dr Fleming, 13 letters from Meinzer to Thiem, one from Dr Fleming to Thiem, one from the Chief Clerk to Thiem, and a copy of a 

English. However, it is clear that both have a good command of the other language. Of the 13 letters of Thiem, only three seem to have been translated. The first letter of 1 December 1936 appears to have been translated by Meinzer himself in handwritten notes on the letter of Thiem (Fig. 11). The second and third translated letters are typewritten with the likely purpose of transferring them to a colleague. Some remarks by Thiem concerning the (upcoming) war in Europe receive particular interest and are translated in English on the original letters in Meinzer's handwriting. On the letter of Thiem of 3 November 1939, Meinzer wrote the translation: "I hope that more peaceful time will soon come and that the scientific exchange will no longer be obstructed". While on Thiem's letter of 28 February 1940, Meinzer wrote as translation: "We all hope that the light of peace will come to Europe from America. Then I will actually make my trip to America which I have had to give up."

It follows from the letters that one or more letters are probably missing and that there might have been correspondence before the first letter of Thiem to Meinzer of 1 December 1936. In this 'first' letter (Fig. 11), Thiem wrote, as translated by Meinzer: "So you have returned safely to America with your esteemed wife! You have seen the birthplace of your parents and have said to yourself how much has occurred since your parents emigrated to the present time. I am glad that you took back with you good impressions of your European journey. You will certainly think back over it often. Mother Europe is indeed very beautiful, but she is also very tired, if one may be permitted to say so. Your country on the contrary is young and full of development possibilities." Thiem further wrote that he was sorry that he could not travel to Edinburgh (for the 1936 International Union of Geodesy and Geophysics (IUGG) General Assembly), as he had hardly any money. Thiem noted that Meinzer travelled to Nancy to see Thiem's good old friend Prof. Imbeaux, a former president of the Commission on Subterranean Water of the IASH-IUGG. Thiem thanked Meinzer that he would send some additional copies of Water-Supply Paper 679-A (i.e. Wenzel, 1936). He also wrote: "Recently I made the acquaintance of the men in the American Institute in Berlin. They were very friendly and lovable, and my wife had to see the institute. These gentlemen also want to get me some copies of this paper. The demand governmental restrictions." In closing the letter, Thiem remarked: "Please tell your esteemed wife many heart greetings from me and my wife. It was a fine afternoon when you took tea with us. Many thanks for the journey ${ }^{1}$ photos. I find them excellent and they will be for me a dear reminder. May you keep real well, and have a happy Xmas; and don't forget your old professional comrade, who greets you many times."

\footnotetext{
${ }^{1}$ Here Mr Meinzer makes an (understandable) translation error; the original in German reads 'reizenden', which means 'lovely', however Meinzer confuses it with 'reisen', which means 'to travel'.
} 
https://doi.org/10.5194/hess-2021-427

Preprint. Discussion started: 4 October 2021

(c) Author(s) 2021. CC BY 4.0 License.
Hydrology and

Earth System

Sciences

Discussions

Leipzig $C 1$, den

Helfferichstraße $g$

Fernsprecher 41582
I.Dez. 1936

Stadtrat a. D.

Beratender Ingenteur

Wasserversorgung

Wasseraufbereitung

Abwasserbeseitigung

Abwasserklürung

Wasseruntersuchung

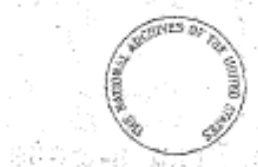

Herrn

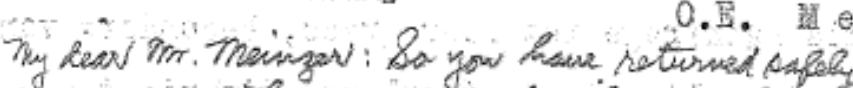

to anerioa with your intermat wife yow hase 2923 South Dakota Ironue IF

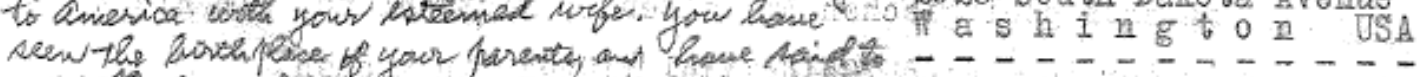
Mourdele how

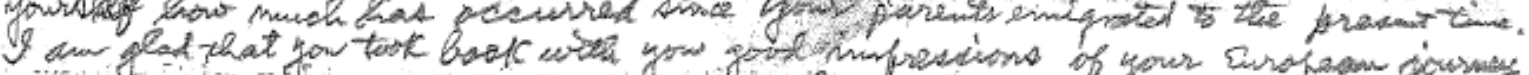

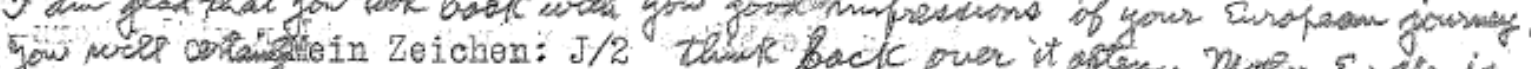

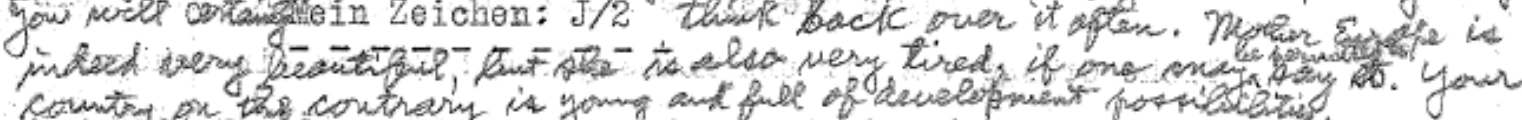

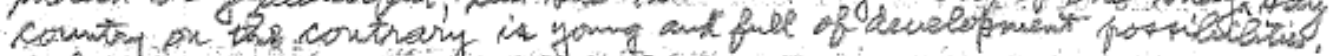

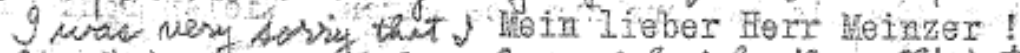

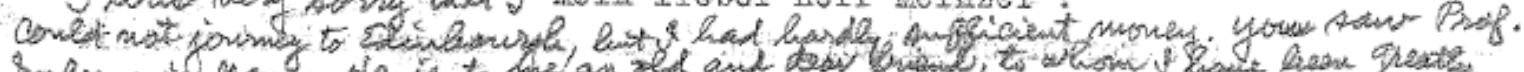

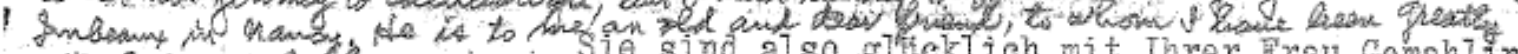
attached, and he hod a ! Sio sind also glfeklich mit Ihror Frau Gomahlin Greot finw of nach Amerika zuriekgekehrt I Sie haben die Heimat Ihror zitem

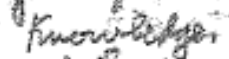

2) thanet yow

wery munt thet schen ereignet hat zwischen der fuswenderung ihrer Bltern gow wiel heid and der hetutigen Beit. Is freut rich, dass ste gute und nachthetional copies haltige Sindrücke von Ihrer Buropa-Reiso mit nsch Haus genomof W.S.P. 679. men haben; Sie werden sicherlich oft darat mrickdenken. Die Recenthy 9 mols. the agranitivere Hutter Europa ist wohl sehr schön, sie ist aber auch sehr ruide, ofthe maw in the wern man so sagen darf; Ihr Iand hingegen ist ein junges Iand American Intetite voller Enteicklungsmöglịchkeiten. in Borlin, They

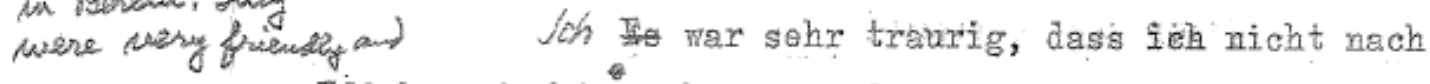
Hinbourgh fahren konnten, doch hätte ich kaum Geld gehabt. Sie haben den Herrn Prof.Jmbeaux in Nancy gesehen; or ist mir ein alter lieber Freund, an dem ich sebr gehangen habe und er verfigt über ein grosses 证issen,

Figure 11: First page of typewritten letter by Günther Thiem with hand-written translation by Oscar Meinzer from December 1, 
Oscar Edward Meinzer was born November 28, 1876, on a farm near Davis, Illinois (Sayre, 1948, 1949b). He was one of six children of William and Mary Julia Meinzer, born in Karlsruhe, Germany. His grandparents and parents emigrated to escape a culture, which they considered oppressive. "This may have directly influenced Meinzer's future religious convictions, independent thought, hatred of war, and industriousness.” (Reuss, 2000). The European travel of Meinzer took place in 1936. He travelled to the IUGG Assembly at Edinburgh, Scotland, but he also visited hydrologists in Germany, Holland and France (Meinzer, 1936: a 4-page trip report, however it was not published and we have not been able to obtain a copy; Waring and Meinzer, 1947; Sayre, 1949a). In the interview of C.V. Theis, CV must have been confused about Meinzer bringing back from this trip the idea of doing a Thiem method pumping test, as the pumping test was executed in 1931 and as there is no indication that Meinzer made an earlier trip to Europe than 1936 (Sayre, 1949a). Meinzer was the first chairman (1930) of the Hydrology Section of the American Geophysical Union (AGU), which served as the American National Committee of the IUGG (Meinzer, 1931). He was also from 1936-1948 president of the Commission on Subterranean Water of the IASH-IUGG, from 1947-1948 president of the AGU and as such, he was active in the organization of the IUGG 1936, 1939 and 1948 Assemblies. He anticipated a second Europe trip to attend the Oslo 1948 IUGG meeting before he passed away (Sayre, 1949a).

Most of the correspondence of Thiem and Meinzer between April 23, 1938, and August 23, 1940, related to a possible participation of Thiem and a contribution to the IUGG $7^{\text {th }}$ Assembly, Washington D.C, September 4-15, 1939. Thiem asked Meinzer for an invitation to participate in the conference, as normally, these invitations only went to the official institutes and not to independent hydrological scientists like him. Thiem also expressed his concern if the German government would provide him with the necessary foreign currency. Meinzer replied that he is happy to note that Thiem and his wife are definitely planning to come to the US, "We will do all that we can to make your visit pleasant and profitable" and "As you know, Mr Wenzel has done a large amount of work on different methods of determining permeability and flow of ground water so that your contact with him will be mutually helpful.” He sends a copy of this letter to Prof. Frolow and Dr. Fleming, the latter General Secretary of the American Geophysical Union and organizer of IUGG 1939 Assembly, and adds a message to Dr Fleming: "Dr. Thiem indicates his intention to come to the Washington meeting and to bring his wife with him, provided he can make the necessary arrangements with the German government. It is obvious to me that he does not stand in very well with the official representatives of Germany but we in this country esteem him very highly." Meinzer asked Thiem to contribute to Question No. 3 of the International Commission on Subterranean Water: 'Determination of runoff and physical conditions of the flow of underground water in natural or altered ground, the flow being natural or induced' of the forthcoming meeting. This question was coordinated by Leland Wenzel of the USGS. Thiem submitted via the official channel of Dr. Koehne of the 'Landesanstalt für Gewässerkunde' in Berlin (Koehne, 1939) his written contribution "Berechnete und beobachtete Grundwassermengen” (Thiem, 1939c, 1940d). Meinzer wrote Thiem June 29, 1939: "Your paper on Question No. 3 with introduction by Dr. Koehne was received a long time ago and is being pre-published for the Washington meeting. Mr. Wenzel and I have read it in part and he will include it in his general report. We find it very interesting." 
July 31, 1939, Thiem reported about his suffering for weeks: "My health has not yet fully improved, for I am suffering in my right knee from rheumatism of the joints so that I cannot bear much weight on it. Also I have trouble going up stairs. [...]You cannot imagine how much my refusal (of your invitation) distresses me." Meinzer replied: "I regret very much that the condition of your health will prevent your attending and taking part in the meetings of the Union. As you know, I had anticipated with pleasure meeting you again and discussing with you personally hydrologic problems of mutual interest." He also noted that he translated Thiem's Assembly paper into English for use at the meeting.

On September 18, 1939, three days after the meeting, Meinzer reported to Thiem: “...although most of the European delegates were not able to attend the meeting in Washington, a considerable number of representative delegates from different countries were nevertheless able to attend and the meeting was very successful. In the Commission on Subterranean Water a total of 55 papers were in hand in either printed or typewritten form, and these were effectively reviewed by the general reporters. The relatively few authors who were present were called upon to present their own papers at greater length. The only one of the officers of the Association who was able to attend was Vice-President Slettenmark who served efficiently as the President during the meetings. President Lutschg's Presidential address, which was submitted in German, was translated and presented by Mr. Slettenmark in the English language. It was accompanied by beautiful lantern slides. We all regretted that you and the other German delegates were not able to attend.” Wenzel (1939) provided a summary on the contributions of Question 3, while Meinzer (1939) reported on Question no. 2: 'Definitions of the different kinds of subterranean water'. Official reports of the Assembly, which took place under the emerging clouds of WWII, are provided in Chapman (1939) and Fleming (1940); "On August 30, when the European political crises was at its height, it was decided... that the Assembly should be held as scheduled but that its activities should be confined to scientific matters only". The IUGG President la Cour closed the Assembly with the words "...it has been an extremely important meeting, furthering our science and showing to the world a battlefield where only victory can be recorded because even the overthrow of a theory is a victory for truth" (Fleming, 1940).

On Jan 6, 1940, Thiem wrote to Meinzer that he received a package with extensive documents of the meeting in Washington and that he now he really regretted that he could not participate. He also noted that he translated into German the Question 3 report of Wenzel (1939) and will publish it in a German professional journal, which he indeed did (Wenzel, 1940). He continued: "It is for me a special recognition that the Thiem method for the estimation of the hydraulic conductivity of the subsurface and its water discharge in your country is applied. Do you think, that it later would be suitable to present myself in America to undertake there hydrological investigations for groundwater supply for cities based on my method? I would be very willing to come to America. I would like to ask you to tell me to whom I should direct myself in this case or do you think that your office could take on the negotiation for my appointment as expert? However, these questions can only be discussed with successful prospect when normal times in Europe, let alone in the world, have set in again.” On February 1, 1940, Meinzer replied to Thiem that he would like to have a copy of the translated report, and "We would be glad to have a visit from you at any time. However, I would not wish to encourage you as to the prospects of obtaining professional work in this country. You 
might be able to make a success of such an undertaking but there are so many difficulties in establishing oneself in a new country that I do not feel at all sure as to the success that you might have." Meinzer was friendly, but he definitely discouraged Thiem from working in the US.

The last letter in the correspondence is from Thiem to Meinzer dated August 23, 1940. Meinzer translated the following lines: "Your friendly letter of April 17 was received by me on Aug. 20 ... I suppose you will not receive my letter till Christmas. Therefore I will already today wish you a merry Christmas. My wife and I send our best greetings to you and your wife. Auf Wiedersehen either in America of Europe. Yours Dr Engineer G. Thiem." It is not known if the correspondence ceased or continued during or after WWII. However, in 1946 shortly after WWII, Meinzer retired as Geologist in Charge of the Division of Ground Water. He died June 14, 1948, rather suddenly while taking an afternoon nap, aged 71 (Sayre, 1948).

In the 1949 address book of Leipzig, Thiem is listed as "Beratender Ingenieur für Wasser und Abwasser, Stadtrat a.D." (Consulting engineer for water and waste water, formerly member of city council), still living in Hillerstraße 9. According to Grahmann (1960), Günther Thiem was active until his death in Leipzig on August 31, 1959, aged 83.

\section{Conclusions}

Forever, the name Thiem will be connected to the Dupuit-Thiem equation, the first practical model for pump test analysis. However, father and son Thiem were far more prolific contributors to the canon of methods currently used in hydrogeology than most people know. All of their method development was done out of practical need, which arose during their many projects while devising solutions for the many problems they were facing building water supply schemes from scratch. This is even more remarkable since it was done besides running a successful consulting business and planning many water supply schemes all over Europe, which today can be found in Germany, Poland, the Czech Republic, Austria, Switzerland, France, Finland, Sweden, Latvia, Romania, Ukraine and Russia (Fig. 12). The infrastructure they planned and designed is a lasting legacy since some of their water works are still active today after often more than 100 years, albeit in modernized form (Fig. 13, 14). A few buildings have been preserved as protected monuments, e.g. in Leipzig, Suceava. The most striking buildings are, of course, the water towers, e.g. in Leipzig (Probstheida, Möckern, Großzschocher), Markranstädt (1895), Liebertwolkwitz (1904, now used for housing), Olesnica (1898, then Oels), and Strasbourg (1878, now a museum of voodoo). 


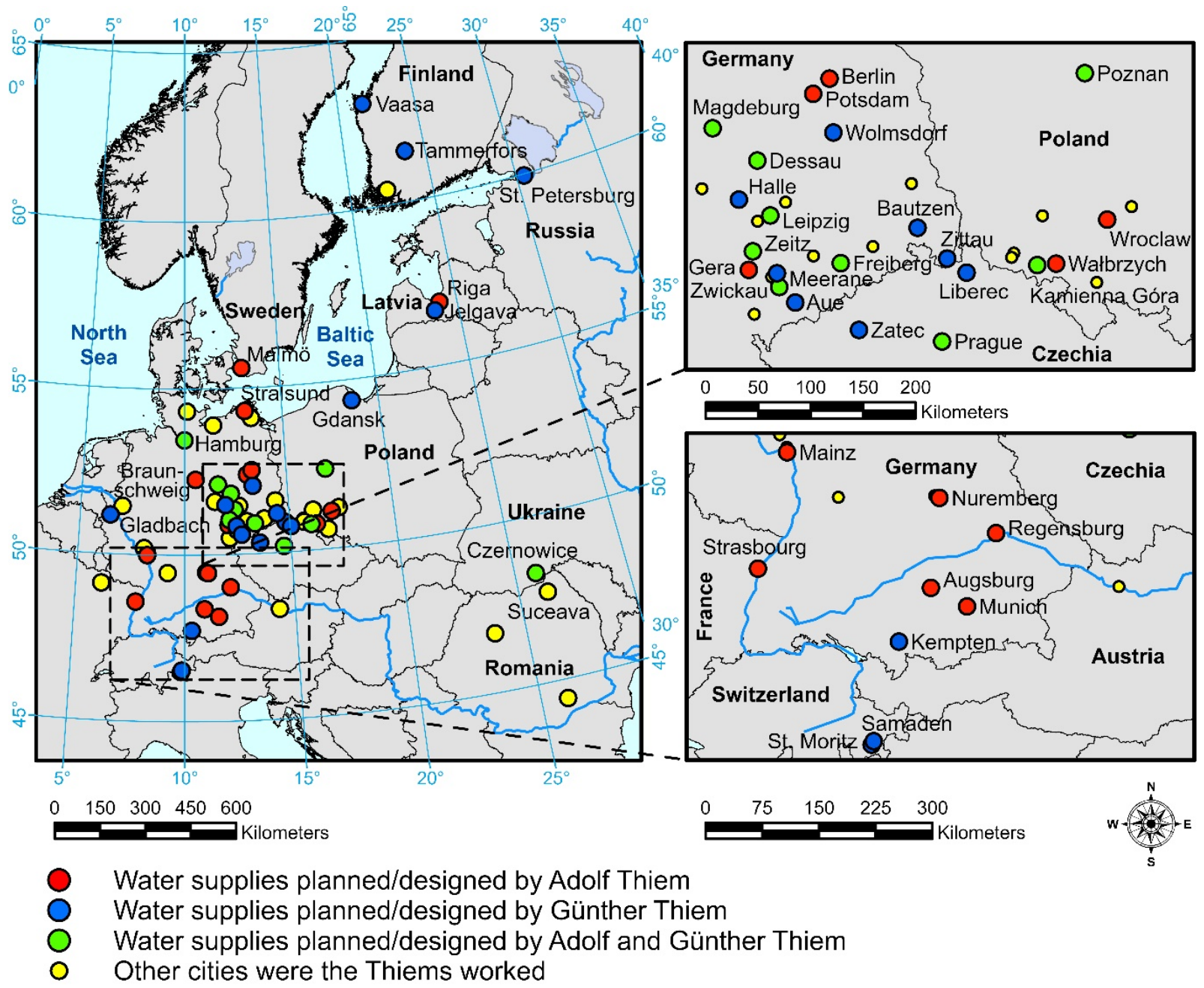

Figure 12: Map of water works planned and designed by Adolf and Günther Thiem.

While most of the Thiem methods, such as isopotential maps, tracer tests and screened vertical wells were devised by Adolf

863 Thiem, who was a true explorer and inventor, it was Günther's role to perfect and propagate them, even in the turmoils of two 864 world wars and several regime changes. Considering the cumbersome communication channels of the late $19^{\text {th }}$ and early $20^{\text {th }}$ century and the language barriers of that time, it is amazing to see that both Thiems were in close contact with many leading scientists from Europe and abroad. The field was small, and the members were well aware of the work of each other; publications in different languages did not seem to be a barrier. Especially Günther's contacts to Oscar Meinzer of the USGS led to the introduction of their methods into the repertoire of English-speaking hydrogeologists. Meinzer's international contacts and his (German) language skills have played a crucial role in the exchange of the strongly developing science of groundwater hydrology. 
https://doi.org/10.5194/hess-2021-427

Preprint. Discussion started: 4 October 2021

(c) Author(s) 2021. CC BY 4.0 License.

Hydrology and $\frac{\text { o }}{2}$

(c) (i)
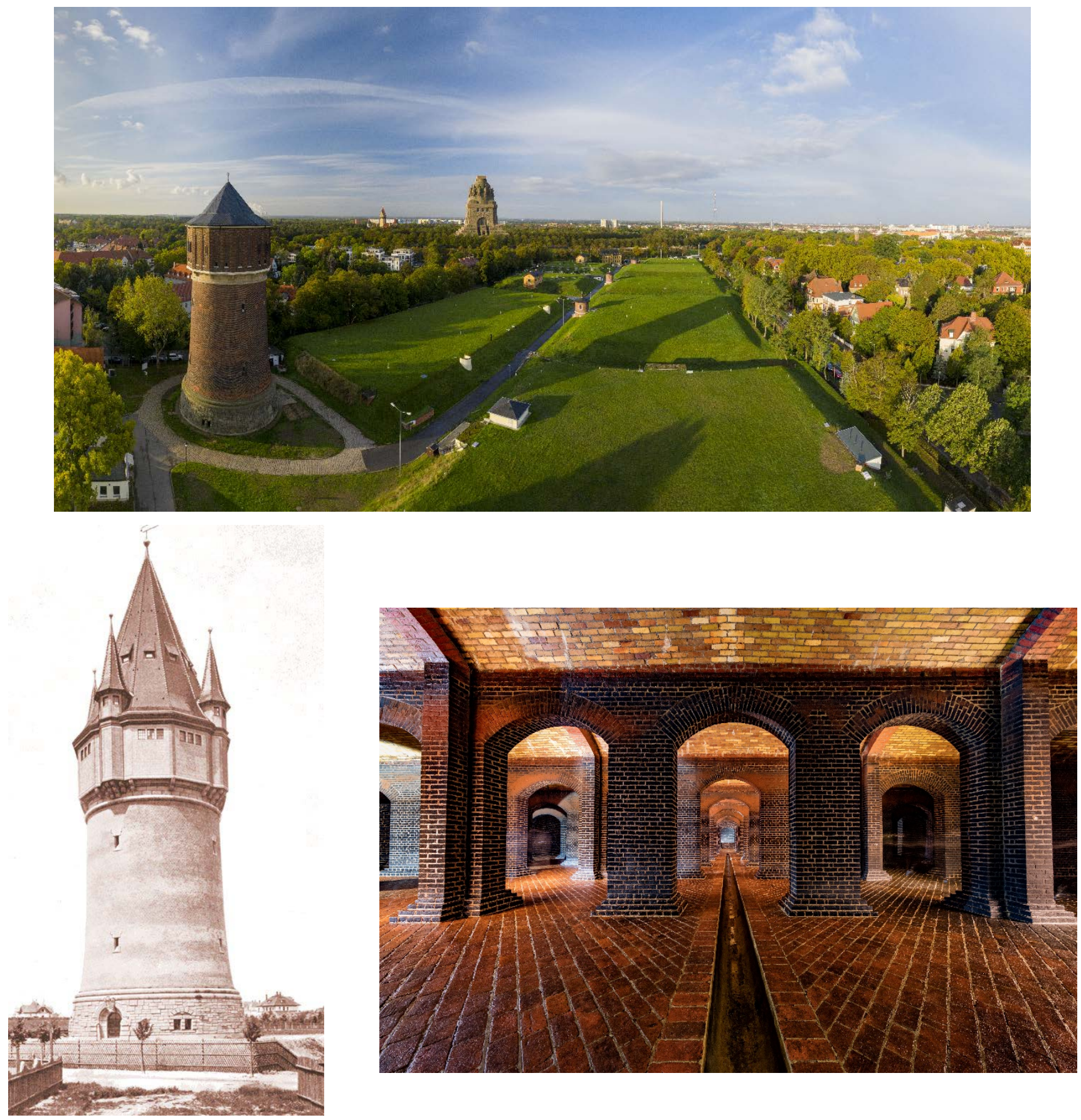

Figure 13: The Probstheida water works, Leipzig, planned and designed by Adolf Thiem: (above) aerial view with the water tower (foreground left) and water storage cellars with grass cover, the tower of the Völkerschlacht Monument is visible in the background, the small tower to its left is part of the chapel of the Südfriedhof where the Thiem family grave is located, (lower left) water tower in its original shape, around 1907, the roof was damaged in WW II and rebuilt in simplified forms, (lower right): inside of water storage cellar (Photos: Leipziger Gruppe, with permission). 
https://doi.org/10.5194/hess-2021-427

Preprint. Discussion started: 4 October 2021

(c) Author(s) 2021. CC BY 4.0 License.
Hydrology and

Earth System

Sciences

Discussions
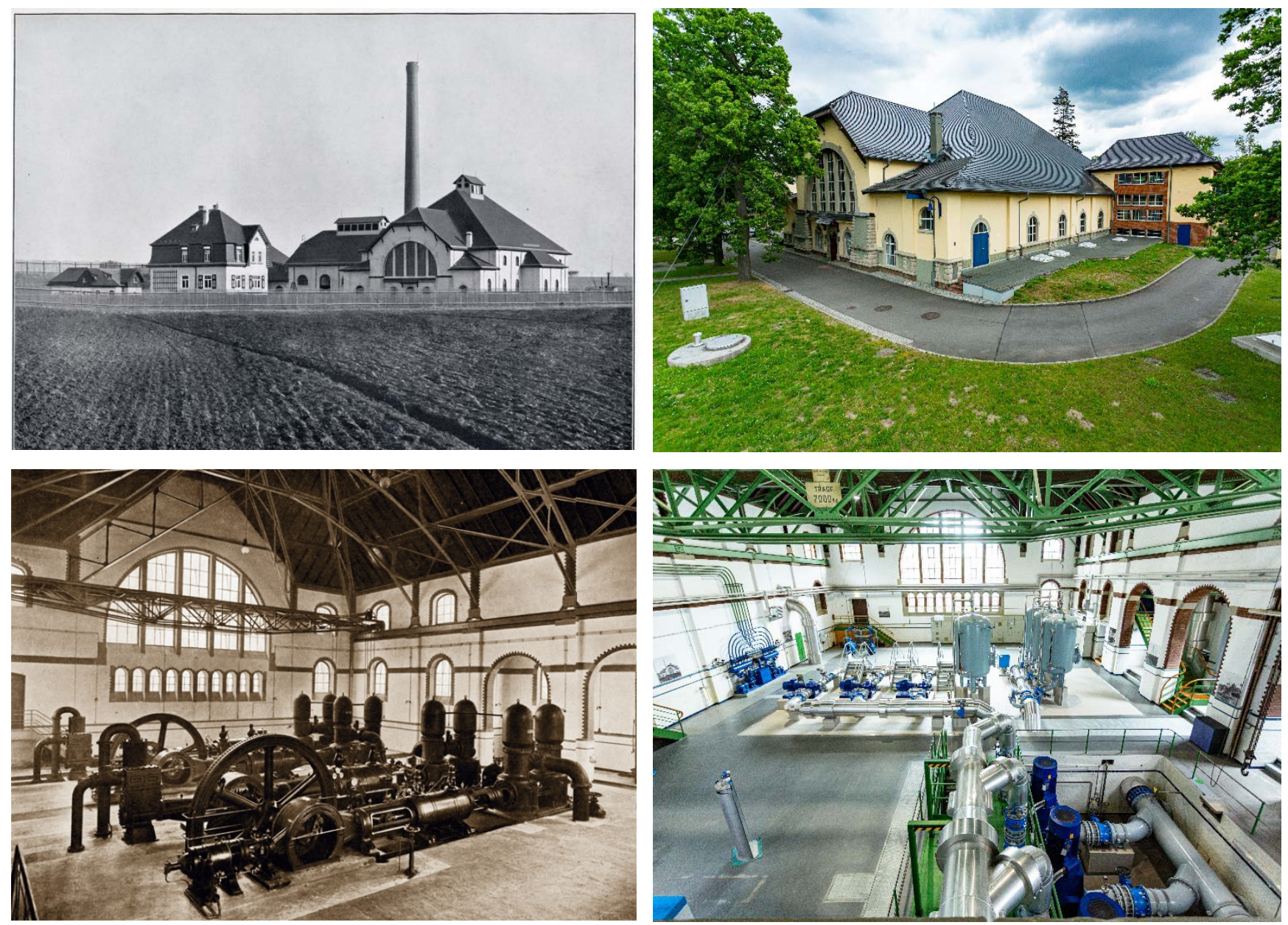

Figure 14: Buildings and pumps of the Canitz water works then and now, Leipzig: (left) as planned and designed by Adolf and Günther Thiem, status 1912, (right): status today (Photos: Leipziger Gruppe, with permission).

Both Adolf and Günther Thiem were highly concerned with the practical applicability of their theoretical work and with presenting it in a way that non-experts could follow their argumentations. In his study for the water supply of Riga, Adolf Thiem stated that "Es war mir nicht darum zu tun, Behauptungen und Schlüsse lediglich vom Standpunkt de Fachmannes aufzustellen, sondern ich beabsichtige vielmehr, auch dem außerhalb des Fachs stehenden Leser den logischen Gang der Untersuchungen klarzulegen und ihn so in die Lage zu versetzen, meine Methode kritisch prüfen zu können. (It was not my intention to present my claims and conclusions solely from the point of view of an expert, but to clearly show to a reader, who is not from the field, the logical structure of my investigations, enabling him to critically judge my method)“ (Thiem 1883b). 
The engineering work of the Thiems can only be understood in the light of the social and technical problems arising during the late 19th and the early 20th century. Increasing population, industrialization and urbanization had increased the water demand but - at the same time - had negatively affected water quality. Groundwater came into focus as a safe, reliable and often abundant resource to overcome both the demand for a sufficient quantity of water and for improved hygiene by better water quality. However, little was known about this mysterious underground resource. The Thiems reacted to this societal problem by adaption of current technology but also by innovation, e.g. the development of new techniques and methods. One example is the vertical well, which design they improved continuously over several decades, paving the way towards the modern-day wells. At the same time, they were early adopters of new technology (e.g. the pumps driven by steam engines used in pumping tests) and new, mass-produced materials (e.g. steel and copper used for wells). Both Thiems were also great educators and their wealth of publications and presentations shows their tireless dedication to the improvement of water supply. Hence, the engineering work of the Thiems was in response to the rapidly changing times in which they were living. However, equally, they benefitted strongly from the developing engineering profession and approaches, providing opportunities for experimenting and creating solutions for societal problems.

The lives and work of Adolf and Günther Thiem are not only documented in their legacy of references, of which we have tried to collect and list as many as possible. Several museums hold collections containing reports, letters and photographs. These include: the archives of the Deutsches Museum (https://www.deutsches-museum.de/en/library/searches/), the Sächsisches Staatsarchiv (Saxonian State Archive), Dresden and the Museum der Leipziger Stadtgeschichte (Museum of City History), Leipzig.

\section{Acknowledgements}

The authors would like to thank to Herfried Apel, a grandson of Adolf Thiem's oldest son Paul Adolf Thiem, for providing access to important information on the Thiem family, including the family tree. We also express our gratitude to the Leipziger Gruppe for providing photographs of the buildings shown in Figure 13 and 14.

\section{References}

Anonymous: Zur Wasserversorgung von Breslau, Journal für Gasbeleuchtung und Wasserversorgung, 45 (22), 386-387, 1902. Anonymous: Vorarbeiten für die Wasserversorgung von Prag, Journal für Gasbeleuchtung und Wasserversorgung, 46 (7), 133134, 1903.

Anonymous: A. Thiem, Journal für Gasbeleuchtung und Wasserversorgung, 49 (7), 156-157, 1906.

Anonymous: A. Thiem, Journal für Gasbeleuchtung und Wasserversorgung 51 (20), 438, 1908. Anonymous: Dr.-Ing. Günther Thiem - Zivil-Ingenieur - Leipzig, Adolf Eckstein, Berlin-Charlottenburg, 1910. 
Anonymous: Amtliches: Dienst-Nachrichten, Zentralblatt der Bauverwaltung, 37 (19), 117, 1917.

Anonymous.: Das Widerstandsgesetz bei der Bewegung des Wassers im Untergrunde, Journal für Gasbeleuchtung und Wasserversorgung, 62 (51), 769-770, 1919.

Anonymous: Dr-Ing. Günther Thiem 60 Jahre, Deutsche Licht- und Wasserfach-Zeitung, 21, 1935.

Anonymous: 75 Jahre Grundwasserforschung; Das Gas- und Wasserfach, 90 (12), 301, 1949.

Anonymous: Dr.-Ing. Günther Thiem 75 Jahre, Bohrtechnik-Brunnenbau, 1 (9), 283, 1950.

Anonymous: Bahnbrecher der öffentlichen Wasserversorgung, Das Gas- und Wasserfach, 93 (8), 193-194, 1952.

Anonymous: Günther Thiem 80 Jahre, Bohrtechnik-Brunnenbau, 6 (9), 262, 1955.

Anonymous: 97. Mitgliederversammlung des DVGW anläßlich der Jahrestagung des deutschen Gas- und Wasserfaches in Berlin am 16. Mai 1956, Das Gas und Wasserfach, 97 (Berichte), 33-35, 1956.

Anonymous: Baurat Adolf Thiem - 50. Todestag; Brunnenbau, Rohrleitungsbau, 9 (6), 268, 1958.

Anonymous: Persönliche Nachrichten; Das Gas- und Wasserfach, 100 (52), 1368, 1959a.

Anonymous: Dr.-Ing. Günther Thiem; Bohrtechnik, Brunnenbau, Rohrleitungsbau, 10 (11), 535, 1959b.

Batu, V.: Aquifer Hydraulics: A Comprehensive Guide to Hydrogeologic Data Analysis, John Wiley \& Sons, New York, 1908. Bear, J.: Hydraulics of Groundwater, Dover Publications Inc., New York, 2007.

Benedikt, J., Girg, P., Kotrla, L., and Takac, P.: Origin of the $\beta$-Laplacian and A. Missbach, Electronic Journal of Differential Equations, 16, 1-17, 2018.

Bennison, E. W.: Ground Water: Its Development, Uses and Conservation, Edward E. Johnson Inc., St. Paul, 1947. Bredehoeft, J. D.: An interview with C.V. Theis, Hydrogeology Journal, 16(1), 5-9, 2008.

Brix, J.: Das Darcysche Gesetz für die Grundwasserbewegung, Internationale Zeitschrift für Wasserversorgung, 2 (12), 101102, 1915.

Campbell, M. D. and Lehr, J. H.: Water Well Technology, MacGraw-Hill, New York, 1973.

Chapman, S.: International Union of Geodesy and Geophysics, Nature, 144, 717, 1939.

Credner, H.: Der Boden der Stadt Leipzig - Erläuterungen zu den geologischen Profilen durch den Boden der Stadt Leipzig und deren nächster Umgebung, 71 p., Leipzig, Hinrichs, 1883.

Darcy, H.: Les Fontaines Publiques de la Ville de Dijon, Victor Dalmont, Paris, France, 1856.

Cooper H. H. and Jacob C. E.: A generalized graphical method for evaluating formation constants and summarizing well field history, Trans. Am. Geophys. Union, 27(4), 526-534, 1946.

Dassargues, A., Batelaan, O., and Anceau, A.: The first potentiometric map. Groundwater (in press), 2021. https://doi.org/10.1111/gwat.13123.

de Vries, J. J.: Early developments in groundwater research in The Netherlands: a societally driven science, in: A history of water, edited by: Tvedt, T. and Oestigaard, T., I.B. Tauris, London, Volume 3: The world of water: 185-206, 2006.

Driscoll, F. G.: Groundwater and Wells, 2nd ed. Johnson Division, St. Paul, 1986.

Dupuit, J.: Traité théorique et pratique de la conduite et de la distribution des eaux, Carilian-Goeury et Dalmont, Paris, 1854. 
Dupuit, J.: Ètudes théoriques et pratiques sur le mouvement des eaux dans le canaux découverts at a travers les terrains perméables avec des considerations relatives au regime des grandes eaux, au débouché al leur donner, et a la marche des alluvions dans le rivieres a fond mobile. $2^{\text {nd }}$ ed., 304 S.; Paris, Dunod, 1863.

Dyck, S.: Adolf Thiem - Pionier der Grundwasserwerke - zu seinem 150. Geburtstag, Wasserwirtschaft-Wassertechnik, 36 (2), 31-32, 1986.

Engemann, K.: Adolf Thiem - Pionier der Grundwasserwerke, Wasserwirtschaft-Wassertechnik, 39 (3), 69-70, 1989.

Feilitzsch, D. von: Die Gas- und Wasserwerke der Stadt Braunschweig, Journal für Gasbeleuchtung und Wasserversorgung, 47 (20), 435-437, 1904.

Fleming, J. A.: Washington Assembly of the International Union of Geodesy and Geophysics and the American Geophysical Union, Science, 91 (2367), 439-442, 1940.

Forchheimer, P.: Wasserbewegung durch Boden [Movement of water through soil], Zeitschrift des Vereines Deutscher Ingenieure, 45, 1736-1741 \& 50, 1781-1788, 1901.

Franke, P.-G. and Kleinschroth, A.: Kurzbiographien Hydraulik und Wasserbau. Persönlichkeiten aus dem Deutschsprachigen Raum, München, Karl M. Lipp Verlag, 1991.

Gagneur, B. and Thiem, G.: Grundwasser-Nachweis für Tammerfors in Finnland, Gesundheits-Ingenieur, 51 (30), 491-492, 1928.

Gagneur, B. and Thiem, G.: Grundwasser-Nachweis für Tammerfors in Finnland, Thiems hydrologische Sammlung, 5, 6 p., Leipzig, Kröner, 1929.

Grahmann, G.: Dr.-Ing. Günther Thiem zum Gedächtnis, Die Wasserwirtschaft, 50 (2), 48, 1960.

Grahn, E.: Die Art der Wasserversorgung der Städte des Deutschen Reiches mit mehr als 5000 Einwohnern, 339 p., Munich, Oldenbourg,1883.

Grahn, E.: Die Städtische Wasserversorgung im Deutschen Reiche sowie von einigen Nachbarländern. Teil II. Die deutschen Staaten außer Preußen, 852 p., Munich/Berlin, Oldenbourg,1902.

Grahn, E. and Thiem, A.: Ueber den in Wasserleitungen nöthigen Druck mit Rücksicht auf Feuerlöschzwecke, Journal für Gasbeleuchtung und Wasserversorgung, 28, 942-949, 1885.

Gruner, H.: P.P. Münchener Gemeinde-Zeitung, 5 (24), 240, 1876.

Gruner, H. and Thiem, A.: Project einer neuen Wasserversorgungsanlage, Journal für Gasbeleuchtung und Wasserversorgung, 17 (18), 640-644, 1874.

Hache, S.: Das Widerstandsgesetz bei der Bewegung des Grundwassers, Das Wasser, 15 (27), 309-311, 1919.

Heinker, H.-H.: Wasser macht Geschichte - 500 Jahre Wasserversorgung in Leipzig, 80p., Leipzig, KWL 2005.

Hendriks, M. R.: Introduction to Physical Hydrology, Oxford University Press, 2010.

Henneberg, L.: Das Widerstandsgesetz bei der Bewegung des Wassers im Untergrunde, Journal für Gasbeleuchtung und Wasserversorgung, 62 (1), 4-10, 1919.

Henneberg, L.: Günther Thiem - Verdienter Techniker des Volkes, Wasserwirtschaft-Wassertechnik, 2 (12), 391, 1952. 
Herzner, A.: Günther Thiem 80 Jahre, Wasserwirtschaft-Wassertechnik, 50 (10), 338, 1955.

Hillger, H. (ed.): Die Columbische Welt-Ausstellung Chicago, 1893 [German edition], Chicago, Combian History Co., 1893. Hocheder, M.: Bestimmung der Durchflußmenge von Grundwasserströmen, Journal für Gasbeleuchtung und Wasserversorgung, 62 (4), 45-47, (29) 406-409, 1919.

Hoffmann, A.: Thiem, Günther, in: Neue Deutsche Biographie, 26, 121 [Online-Version], https://www.deutschebiographie.de/pnd117336645.html\#ndbcontent, 2017.

Houben, G.: Hydraulics of water wells. Flow laws and influence of geometry, Hydrogeology Journal, 23 (8), 1633-1657, 2015a.

Houben, G.: Hydraulics of water wells. Head losses of individual components, Hydrogeology Journal, 23 (8), 1659-1675, 2015b.

Houben, G. J.: Die Rolle des Grundwassers bei der Entwicklung der Wasserversorgung im deutschsprachigen Raum bis zum Beginn des 20. Jahrhunderts [The role of groundwater in the development of water supply in the German-speaking countries up to the beginning of the $20^{\text {th }}$ century], Schriftenreihe FH-DGGV 1., Fachsektion Hydrogeologie e.V. in der DGGV e.V., Neustadt, 2019.

Imbeaux, E.: Methode de Thiem, dite Epsilon, pour l'evaluation des eaux d'une nappe souterraine (alluvions), Le Genie Civile, 79 (18), 370-371, 1921.

Imbeaux, E.: Essai d'hydrogéologie: recherche, étude et captage des eaux souterraines, Paris, Dunod, 1930.

Juuti, P. and Katko, T.: Vaasan Vedet - Vasa och dess Vatten, 534 p., Tampere, Tampere University Press, 2006.

Kasenow, M.: Applied Ground-water Hydrology and Well Hydraulics, 3rd ed. Water Resources Publications, 2010.

King, F. H. and Slichter, C. S.: Principles and conditions of the movement of groundwater with a theoretical investigation of the motion of ground waters, 384 p., Washington, Government Printing Office, 1899.

Koehne, W.: Bestimmung der Menge und der physikalischen Verhältnisse des unterirdischen Abflusses in natürlichem oder bearbeitetem Gelände bei natürlicher oder künstlich erzeugter Wasserbewegung. Einleitung, International Union of Geodesy and Geophysics, 7th Assembly, Washington D.C., Comptes-rendus et rapports de la reunion de Washington 1939 , Comptes rendus des Seances et Rapports, Volume II, 1939.

Kresic, N.: Quantative Solutions in Hydrogeology and Groundwater Modeling, CRC Press, Florida, 1997.

Krüger, E.: Die Grundwasserbewegung, Internationale Mitteilungen für Bodenkunde, 8 (5/6), 105-122, 1918.

Kruseman, G. P. and de Ridder, N. A.: Analysis and Evaluation of Pumping Test Data., $2^{\text {nd }}$ revised version, Wageningen, The Netherlands, International Institute for Land Reclamation and Improvement, 2000.

Lang, A.: Günther Thiem, Das Gas- und Wasserfach, 91 (18), 232, 1950.

Loehnert, E. P.: History of hydrogeology in Central Europe, particularly relating to Germany, in: History of Hydrogeology, edited by: Howden, N. and Mather, J., London, CRC Press, 101-116, 2013.

Lueger, O.: Theorie der Bewegung des Grundwassers in den Alluvionen der Flussgebiete, Stuttgart, P. Neff, 1883.

Lueger, O.: Die Wasserversorgung der Städte, Darmstadt, Bergsträsser, 1895. 
Lummert, R.: Über die Wasserversorgung der Stadt Waldenburg, Journal für Gasbeleuchtung und Wasserversorgung, 48 (10), 196-200, 1905.

Lummert, R.: Neue Formeln für die Absenkung des Grundwassers durch Brunnen und Sammelgalerien, Journal für Gasbeleuchtung und Wasserversorgung, 59 (6), 88-91, 1916a.

Lummert, R.: Neue Formeln für die Absenkung des Grundwassers durch Brunnen und Sammelgalerien - Entgegnung auf die „Berichtigung“ seitens Dr. O. Smreker, Journal für Gasbeleuchtung und Wasserversorgung, 59 (39), 493-496, $1916 \mathrm{~b}$. Lummert, R.: Zur Berechnung der Ergiebigkeit von Grundwasserströmen, Journal für Gasbeleuchtung und Wasserversorgung, 60 (50), 634-636, 1917a.Lummert, R.: Neue Methode zur Bestimmung der Durchlässigkeit wasserführender Bodenschichten, Braunschweig, Vieweg, 1917b.

Meinzer, O. E. and Hard, H. A.: The artesian water supply of the Dakota sandstone in North Dakota, with special reference to the Edgeley quadrangle: Chapter E in Contributions to the hydrology of the United States, 1923-1924, Water Supply Paper, Washington, D.C., 73-95, 1925.

Meinzer, O. E.: Compressibility and elasticity of artesian aquifers, Economic Geology, 23 (3), 263-291, 1928.

Meinzer, O. E.: Formation of the section of hydrology of the American Geophysical Union, EOS, Transactions American Geophysical Union, 12 (1), 227-229, 1931.

Meinzer, O. E.: Outline of methods for estimating ground-water supplies, Washington. U.S. Geol. Survey Water-Supply Paper 638-C, 144 p., 1932.

Meinzer, O. E.: The history and development of ground-water hydrology, Journal of the Washington Academy of Science, 24 (1), 6-32, 1934.

Meinzer, O. E.: Hydrology in Europe, Unpublished Mimeographed document, USGS, 4 p., 1936.

Meinzer, O. E.: Discussion of question no. 2 of the International Commission on Subterranean Water: Definitions of the different kinds of subterranean water, Eos, Transactions, American Geophysical Union 20 (4), 674-677, 1939. Gruner, Basel, 1962. Oesten, G.: Ueber Brunnen, Journal für Gasbeleuchtung und Wasserversorgung, 22 (12), 407-412, (13), 452-458, 1879a. Oesten, G.: Entgegnung auf die „Kritischen Bemerkungen“ des Herrn A. Thiem in No. 15 dieses Journals, Journal für Gasbeleuchtung und Wasserversorgung, 22 (19), 636-637, 1879b.Oesten, G.: Über Grundwasserfassung durch Brunnen [On the capture of groundwater by wells], Wochenschrift Verein Deutscher Ingenieure, 48, 245-249, 1882a. Oesten, G.: No title, reply to: Thiem A (1882) Zur Wirkungsweise von Schachtbrunnen, Wochenschrift Verein Deutscher Ingenieure, 48, 451-452, 1882b. 
Oesten, G.: Die Wasserversorgung der Städte. 416 p., Leipzig, Engelmann, 1904.

Paavel, V.: Persönliche Nachrichten: Günther Thiem, Das Gas- und Wasserfach, 96 (20), 691-692, 1955.

Pfeffer, W.: Wasserenteisenung in Dessau, Journal für Gasbeleuchtung und Wasserversorgung, 49 (46), 1015, 1906.

Prinz, E.: Die Trockenhaltung des Untergrundes mittels Grundwassersenkung, Journal für Gasbeleuchtung und Wasserversorgung, 50 (2), 34-39, 1907.

Prinz, E.: Handbuch der Hydrologie [Handbook of Hydrology], Springer, Berlin, 1919.

Prinz, E.: Adolf Thiem (Zu seinem 100. Geburtstag), Gas- und Wasserfach, 79 (8), 127, 1936.

Reuss, M.: Meinzer, Oscar Edward (1876-1948), hydrogeologist, American National Biography, Oxford University Press, 2000.

Richert, J. G.: Die Grundwasser mit besonderer Berücksichtigung der Grundwasser Schwedens [The groundwaters, featuring the groundwater of Sweden], München/Berlin, Oldenbourg, 1911.

Ritzi, R. W., Jr. and Bobeck, P.: Comprehensive principles of quantitative hydrogeology established by Darcy (1856) and Dupuit (1857), Water Resources Research, 44 (10), W10402, doi:10.1029/2008WR007002, 2008.

Rother, M.: Zur Ehrenrettung des Darcyschen Gesetzes in seiner Anwendung auf die Bewegung des Grundwassers, Internationale Zeitschrift für Wasserversorgung, 2 (3), 21-23, (10), 87-89, (11), 95-96, (12), 104-107, 1915.

Rother, M.: Zur Ehrenrettung für das Darcysche Gesetz, Internationale Zeitschrift für Wasserversorgung, 3 (4), 31-33, 3 (9): 71-, 1916.

Rother, M.: Zur richtigen Bewertung des Smrekerschen Gesetzes, Journal für Gasbeleuchtung und Wasserversorgung, 62 (22), 289-294, (23) 306-312, 1919.

Rother, M.: Erwiderung auf die Bemerkungen Smrekers in Nr. 35, Jahrg. 1919 ds. Journals, Journal für Gabeleuchtung und Wasserversorgung, 63 (7), 105-106, 1920.

Salm, R.: Zur Frage der Wasserversorgung Rigas, Rigasche Industrie-Zeitung, 19 (6), 61-66, 1893.

Sauer, A. Erläuterungen zur geologischen Specialkarte des Königreichs Sachsen, Blatt 27, Section Naunhof, 41-44, Leipzig, Engelmann,1881.

Sauer, A., Danzig, E. and Thiem, A.: Geologische Specialkarte des Königreichs Sachsen. Leipzig, Engelmann, 67 p., 1906.

Sayre, A. N.: Oscar Edward Meinzer, Eos, Transactions American Geophysical Union, 29 (4), 455-456, 1948.

Sayre, A. N.: Memorial to Oscar Edward Meinzer, Proceedings volume of the Geological Society of America for 1948, 197206, 1949a.

Sayre, A. N.: Oscar Edward Meinzer, 1876-1948: A memorial, Economic Geology and the Bulletin of the Society of Economic Geologists, 44 (3), 248-250, 1949b.

Schöne, W.: Ein Leben als Hydrologe und Montanhydrologe, Bergbautechnik, 6 (6), 336-337, 1956.

Schöne, W.: Günther Thiem gestorben, Wasserwirtschaft-Wassertechnik, 9 (12), 525, 1959.

Slichter, C. S.: Elektrische Messung unterirdischer Strömungen in den Vereinigten Staaten, Internationale Zeitschrift für Wasserversorgung, 2 (9), 73-75, 1915. 
Smreker, O.: Entwicklung eines Gesetzes für den Widerstand bei der Bewegung des Grundwassers, Zeitschrift des Vereins Deutscher Ingenieure, 22 (4), 117-128, 22 (5), 193-204, 1878.

Smreker, O.: Das Grundwasser und seine Verwendung zu Wasserversorgungen, Zeitschrift des Vereins Deutscher Ingenieure, 23 (8), 347-361, 1879a.

Smreker, O.: Die Depressionsfläche bei Schachtbrunnen, Zeitschrift des Vereins Deutscher Ingenieure, 25, 283-294, 353-362, 411-418, 483-429, 1881.

Smreker, O.: Die Erscheinungsformen des Grundwassers, Zeitschrift des Vereins Deutscher Ingenieure, 27, 681-692, 1883. Smreker, O.: Hydrologische Untersuchungen von Grundwassergebieten mit spezieller Rücksichtnahme auf diesbezügliche Untersuchungen in der Umgebung von Mannheim, Journal für Gasbeleuchtung und Wasserversorgung, 50 (40), 905-911, 1907.

Smreker, O.: Das Grundwasser, seine Erscheinungsformen, Bewegungsgesetze und Mengenbestimmung [Groundwater, its forms of occurrence, laws of movement and assessment of quantity], PhD Thesis, ETH Zurich, Zurich, Switzerland, 1914a. Smreker, O.: Die Wasserversorgung der Städte [The water supply of towns], Engelmann, 1914b. Smreker, O.: Das Widerstandsgesetz bei der Bewegung des Grundwassers, Internationale Zeitschrift für Wasserversorgung, 2, 193-194, 1915a. Smreker, O.: Das Widerstandsgesetz bei Grundwässern, Internationale Zeitschrift für Wasserversorgung, 2 (23), 193-194, 1915c. Internationale Zeitschrift für Wasserversorgung, 2 (13), 113-114, 2 (14), 121-123, 1915e. Smreker, O.: Das Widerstandsgesetz bei der Bewegung des Grundwassers, Journal für Gasbeleuchtung und Wasserversorgung, 58 (32), 452-456, (33) 471-473, (34) 482-490, (35) 505-506, 1915e.

1112 Smreker, O.: Bemerkungen zu dem Rotherschen Aufsatze "Zur Ehrenrettung für das Darcysche Gesetz“, Internationale 1113 Zeitschrift für Wasserversorgung, 3 (15), 121, 1916a.

1114 Smreker, O.: Neue Formeln für die Absenkung des Grundwassers durch Brunnen und Sammelgalerien (Berichtigung der 1115 Abhandlung von Dipl.-Ing. R. Liummert), Journal für Gasbeleuchtung und Wasserversorgung, 59 (21), 277-281,1916b. 1116 Smreker, O.: Bestimmung der Durchflußmenge von Grundwasserströmen, Journal für Gasbeleuchtung und Wasserversorgung, 111761 (24) 281-285, (26) 306-311, (27) 317-322, 1918.

1118 Smreker, O.: Erwiderung auf M. Rother: Zur richtigen Wertung des Smreker’schen Widerstandsgesetzes für die 1119 Grundwasserbewegung, Journal für Gasbeleuchtung und Wasserversorgung, 62 (4), 47-48, 500-504, 1919a.

1120 Smreker, O.: Bestimmung der Durchflußmenge von Grundwasserströmen, Journal für Gasbeleuchtung und Wasserversorgung, 112162 (51), 768-769, 1919b.Smreker, O.: Ueber hydrologische Vorarbeiten und Mengenbestimmung bei 1122 Grundwasserversorgungen, Zeitschrift des Vereins deutscher Ingenieure, 64 (12), 282-283, 1920a. 
1123 Smreker, O.: Antwort auf die Erwiderung Rothers in Nr. 7, Jahrg. 1920, S. 105 ds. Journ., Journal für Gasbeleuchtung und 1124 Wasserversorgung, 63 (25), 406, 1920b.

1125 Smreker, O.: Bemerkungen zur Rotherschen Arbeit - Zur richtigen Wertung des Smrekerschen Widerstandsgesetzes für die 1126 Grundwasserbewegung - dieses Journal 1919, Nr. 22 und 23, Journal für Gasbeleuchtung und Wasserversorgung, 62 (35), 1127 500-504, 1920c.

1128 Sterrett, R. J.: Groundwater and Wells, 3rd ed, Johnson Screens, New Brighton, 2007.

1129 Stoffers, G.: Deutschland in Brüssel 1910, Köln, Dumont Schauberg, 1910.

1130 Svensson, C.: Hydrogeology in Sweden; in: History of Hydrogeology, edited by: Howden, N. and Mather, J., London, CRC 1131 Press, 317-345, 2013.

1132 Theis, C. V.: The relation between lowering of the piezometric surface and rate and duration of discharge of a well using 1133 groundwater storage, Transactions of the American Geophysical Union, 16, 519-524, 1935.

1134 Theis, C. V.: C.V. Theis: Full interview by John Bredehoeft, https://youtu.be/PVtpC-Gxcs4, J. Bredehoeft. 13 Nov., 1135 Albuquerque, New Mexico, U.S. Geological Survey, 1985.

1136 Thiem, A.: Beschreibung einer Druckverminderungs-Vorrichtung, Journal für Gasbeleuchtung und verwandte 1137 Beleuchtungsarten, 4, 318-320, 1861.

1138 Thiem, A.: Specification des Betriebes der Gasanstalt zu Liegnitz pro 1861, Journal für Gasbeleuchtung und verwandte 1139 Beleuchtungsarten, 5, 283-285, 1862.

1140 Thiem, A.: Über eine Contrebalance bei Gasometern, Journal für Gasbeleuchtung und verwandte Beleuchtungsarten, 7, 55$114157,1864$.

1142 Thiem, A.: Relation zwischen Niveaulage und Spannung des Gases in Röhrenleitungen, Journal für Gasbeleuchtung und 1143 verwandte Beleuchtungsarten, 9, 173-177, 1866.

1144 Thiem, A.: Die Ergiebigkeit artesischer Bohrlöcher, Schachtbrunnen und Filtergalerien [The yield of artesian boreholes, shaft 1145 wells and filter galleries], Journal für Gasbeleuchtung und Wasserversorgung, 13, 450-467, 1870.

1146 Thiem, A.: Die Belastungsgrenze von sogennanten Mantelröhren, Journal für Gasbeleuchtung und Wasserversorgung, 19, 2011147 207, 1876a.

1148 Thiem, A.: Resultate des Versuchsbrunnen für die Wasserversorgung der Stadt Strassburg, Journal für Gasbeleuchtung und 1149 Wasserversorgung, 19, 707-719, 1876b.

1150 Thiem, A.: Die Rohr-Unterführungen des Regensburger Wasserwerkes durch die Donau und den Regen, Deutsche Bauzeitung, 1151 1/2, 2-4, 6, 21-22, 1877a.

1152 Thiem, A.: Die Wasser-Versorgung der Stadt München. Vorprojekt im Auftrag der beiden Gemeinde-Collegien, 85 p., 1153 München, Mühltaler, 1877b.

1154 Thiem, A.: Zur Ergiebigkeitsbestimmung von Rohrleitungen, Journal für Gasbeleuchtung und Wasserversorgung, 21, 668$1155671,1878$. 
1156 Thiem, A.: Das Wasserwerk der Stadt Nürnberg - Project im Auftrag der beiden Gemeinde-Collegien, 55p., Leipzig, Knapp, 1157 1879a.

1158 Thiem, A.: Die Ergiebigkeitsbestimmung eines artesischen Beckens, Journal für Gasbeleuchtung und Wasserversorgung, 22 1159 (15), 518-521, 1879b.

1160 Thiem, A.: Kritische Bemerkungen über den Artikel: Ueber Brunnen von G. Oesten (in No. 12 dieses Journals), Journal für 1161 Gasbeleuchtung und Wasserversorgung, 22 (15), 515-518, 1879c.

1162 Thiem, A.: Das Grundwasser und seine Verwendung zu Wasserversorgungen, Berichtigende Bemerkungen zu der in Band 1163 XXIII, p. 347 enthaltenen Abhandlung von Oscar Smreker, Zeitschrift des Vereins Deutscher Ingenieure, 24, 101-102, 1879d.

1164 Thiem, A.: Der Versuchsbrunnen für die Wasserversorgung der Stadt München, Journal für Gasbeleuchtung und 1165 Wasserversorgung, 23, 156-164, 196-204, 227-235, 1880a.

1166 Thiem, A.: Die Wasserversorgung der Gegenwart, Journal für Gasbeleuchtung und Wasserversorgung, 23 (16), 472-478, $11671880 \mathrm{~b}$.

1168 Thiem, A.: Ueber Druckhöhenverluste in geschlossenen Rohrleitungen. Journal für Gasbeleuchtung und Wasserversorgung, 1169 23, 586-588, 1880c.

1170 Thiem, A.: Zur Wasserversorgung Münchens. Journal für Gasbeleuchtung und Wasserversorgung, 23: 596-599, 1880d.

1171 Thiem, A.: Bericht über die hydrographische Untersuchung des Rednitzthales zwischen Bibertmündung und Bahnbrücke bei 1172 Fürth, Journal für Gasbeleuchtung und Wasserversorgung, 24, 573-575, 1881a.

1173 Thiem, A.: Ein Beitrag zur Kenntnis der Grundwasserverhältnisse im norddeutschen Tieflande, Journal für Gasbeleuchtung 1174 und Wasserversorgung, 24, 686-695, $1881 \mathrm{~b}$.

1175 Thiem, A.: Zur Wirkungsweise von Grundwasserfassungen, Journal für Gasbeleuchtung und Wasserversorgung, 24, 782-792, 1176 1881c.

1177 Thiem, A.: Zur Hydrologie des alten Strombettes der Mulde bei Naunhof. in: Sauer, A. Erläuterungen zur geologischen 1178 Specialkarte des Königreichs Sachsen, Blatt 27, Section Naunhof, 37-47, 1881d.

1179 Thiem, A.: Bericht an den Hohen Rath der Stadt Leipzig über die hydrologische Untersuchung der Umgebung von Naunhof, 118042 p., Munich, Wolf, 1881e.

1181 Thiem, A.: Zur Wirkungsweise von Schachtbrunnen. Wochenschrift des Vereins Deutscher Ingenieure, 48, 451-452, 1882.

1182 Thiem, A.: Der Versorgungsdruck städtischer Wasserleitungen, Journal für Gasbeleuchtung und Wasserversorgung, 25, 6891183 693, 1883a.

1184 Thiem, A.: Bericht über die neuen Bezugsquellen für Wasserversorgung der Stadt Riga; im Auftrage der Verwaltung der 1185 ständischen Gas- und Wasser-Werke, 100 p., Munich, Wolf, $1883 b$.

1186 Thiem, A.: Das Wasserwerk der Stadt Leipzig, 36 p., Leipzig, 1883c.

1187 Thiem, A.: Erwärmung des Wassers in Rohrleitungen, Journal Gasbeleuchtung und Wasserversorgung, 27 (1) 8-12, 1884a.

1188 Thiem, A.: Anlage und Betriebsergebnisse deutscher Wasserwerke, Journal Gasbeleuchtung und Wasserversorgung, 27, 4111189 423, 467-475, 495-503, 518-527, 1884b. 
1190 Thiem, A.: Bericht über die hydrologische Untersuchung der Umgebung von Gera, 53 p., Munich, Wolf, 1884c.

1191 Thiem, A.: Bau und Betrieb einer neuen Brunnenform, Journal für Gasbeleuchtung und Wasserversorgung, 28, 140-147, 1192 1885a.

1193 Thiem, A.: Ueber graphische Durchmesserbestimmung von Wasserleitungen, Journal für Gasbeleuchtung und 1194 Wasserversorgung, 28, 748-754, 1885b.

1195 Thiem, A.: Über den in Wasserleitungen nöthigen Druck mit Rücksicht auf Feuerlöschzwecke. Journal für Gasbeleuchtung 1196 und Wasserversorgung. 28, 948-953, 1885c.

1197 Thiem, A.: Verfahren für Messung natürlicher Grundwassergeschwindigkeiten, Polytechn- Notizblatt, 42, 229-232, 1887a.

1198 Thiem, A.: Über Wasserbeschaffung für Städte, Zeitschrift des Vereins Deutscher Ingenieure, 31 (52), 1133-1139, 1887b.

1199 Thiem, A.: Neue Messungsart natürlicher Grundwassergeschwindigkeiten, Journal für Gasbeleuchtung und 1200 Wasserversorgung, 31, 18-28, 1888a.

1201 Thiem, A.: Zur Beurtheilung von Wasserversorgungsanlagen. Journal für Gasbeleuchtung und Wasserversorgung, 31, 365, 1202 1888b.

1203 Thiem, A.: Eine besondere Art der Wasserfiltration. Journal für Gasbeleuchtung und Wasserversorgung, 31, 365-366, 1888c.

1204 Thiem, A.: Zur Wasserversorgung Stralsunds, Deutsche Vierteljahrsschrift für öffentliche Gesundheitspflege, 20, 140-147, 1205 1888d.

1206 Thiem, A.: Wasserversorgung der Stadt Riga, München, 1888e.

1207 Thiem, A.: Bericht über die Wasserversorgung der Vororte der Stadt Leipzig, 11 p., Leipzig, Bär \& Hermann, 1889.

1208 Thiem, A.: Bericht über die hydrologische Untersuchungen des Geländes bei Böhlitz-Ehrenberg und des westlichen Theiles 1209 des Naunhofer Staatswaldes, 12 p., Leipzig, Bär \& Hermann, 1890a.

1210 Thiem, A.: Erläuterungsbericht zum Projekt der Wasserversorgungsanlagen im erweiterten Stadtgebiet rechts der Pleiße, 20 1211 p., Leipzig, Bär \& Hermann, 1890b.

1212 Thiem, A.: Vermehrte Wassererschliessung für Leipzig, Journal für Gasbeleuchtung und Wasserversorgung, 34 (10), 195-198, 12131891.

1214 Thiem, A.: Grundwasserströme, in: Leipzig und seine Bauten, Gebhardt, Leipzig, 21-31, 1892a.

1215 Thiem, A.: Die Wasserversorgung, in: Leipzig und seine Bauten, Gebhardt, Leipzig, 572-583, 1892b.

1216 Thiem, A.: La traction des bateaux sur la ligne de Hohensaaten à Spandau, Ve Congres international de navigation interieure, 1217 Paris 1892, 1892c.

1218 Thiem, A.: Bericht über die Erweiterung des Wasserwerks der Stadt Potsdam, 11 p., Potsdam, von Müller, 1892d.

1219 Thiem, A.: Ventilanordnung an combinierten Flüssigkeitsmessern. German patent No. 77398 (April 22, 1894), 1894a.

1220 Thiem, A.: Ueber die Versorgung der Städte mit Brunnen. Hygienische Rundschau, 4 (22), 1036-1056, 1894b.

1221 Thiem, A.: Zur Enteisenung des Grundwassers, Journal für Gasbeleuchtung und Wasserversorgung, 39 (45), 738-739, 1896.

1222 Thiem, A.: Die Charlottenburger Enteisenungs-Anlagen, Journal für Gasbeleuchtung und Wasseversorgung, 40 (1), 12, 1897a.

1223 Thiem, A.: Grundzüge für die Erweiterung des Wasserwerks der Stadt Mainz, 12 p., Mainz, Wirth, 1897b. 
1224 Thiem, A.: Bericht über die hydrologische Untersuchung des Geländes bei Laubenheim, 19 p., Mainz, Wirth, 1897c.Thiem, A.: Die künstliche Erzeugung von Grundwasser, Journal für Gasbeleuchtung und Wasserversorgung, 41 (12), 189-193, (13), 207-212, 1898a. Thiem, A.: Der Woltmansche Flügel als Wassermesser, Journal für Gasbeleuchtung und Wasserversorgung, 41 (16), 260-261, 1898b.

1229 Thiem, A.: Bericht über die Wasserfassung des Versuchsbrunnens im Fiener Bruch, 8 p., 1904.

1230 Thiem, A.: Bericht über die Vorarbeiten zur Erweiterung der Wasserversorgung der Stadt Leipzig, 23 p., Leipzig, Thiem \& 1231 Söhne, 1906.

1232 Thiem, A.: Die hydrologischen Vorarbeiten für das dritte Wasserwerk der Stadt Leipzig, Journal für Gasbeleuchtung und 1233 Wasserversorgung, 51 (35), 790-798, 1908.

1234 Thiem, A.: Die Hydrologie in der südlichen Umgebung Münchens, Internationale Zeitschrift für Wasserversorgung, 1 (12), 1235 193-198, 1914.

1236 Thiem, A.: Erwärmung des Wassers in Rohrleitungen, Internationale Zeitschrift für Wasserversorgung, 2 (22), 185-186, 1915.

1237 Thiem, A.: Die Wirkungsweise von Schachtbrunnen auf den wasserführenden Untergrund, Internationale Zeitschrift für 1238 Wasserversorgung, 5 (5/6), 22-23, 1918.

1239 Thiem, A.: Ergebnisse des Versuchsbrunnens für Wasserversorgung der Stadt Strassburg i. E., Zeitschrift für 1240 Wasserversorgung und Abwasserkunde, 7 (17/18), 67-70, (19/20), 77-80, 1920.

1241 Thiem, A.: Die Entwicklung der Gleichungen für die Ergiebigkeit von Grundwasserfassungen, Bohrtechnik-Brunnenbau, 7 1242 (5), 156-159, 1956.

1243 Thiem, A., Fränkel, C.: Die Frage der Versorgung Magdeburgs mit Grundwasser, Verhandlungen und Mittheilungen des 1244 Vereins für öffentliche Gesundheitspflege in Magdeburg, 28/29, 115-119, 1902.

1245 Thiem, G.: Hydrologische Methoden [Hydrological methods], PhD Thesis, University of Stuttgart, Stuttgart, Germany, 1906.

1246 Thiem, G.: Lagerungszustände und Durchlässigkeit der Geschiebe. Journal für Gasbeleuchtung und Wasserversorgung 50 1247 (17): 377-382, 1907.

1248 Thiem, G.: Ableitung von Höhenschichtenplänen künstlich erzeugter Grundwasserspiegel, Journal für Gasbeleuchtung und 1249 Wasserversorgung, 51 (9), 177-182, (10) 197-203; 1908a.

1250 Thiem, G.: Messwerkzeug für die Lagebestimmung des Grundwasserspiegels, Gesundheits-Ingenieur, 31, 785-787, 1908b.

1251 Thiem, G.: Beurteilung der hydraulischen Zustände von Wasserfassungen, Journal für Gasbeleuchtung und Wasserversorgung, 125252 (12), 260-266, 1909a.

1253 Thiem, G.: Wasserversorgung der Stadt Landeshut i. Schles., Journal für Gasbeleuchtung und Wasserversorgung, 52 (39), 1254 260-266, 52 (40), 872-879, 1909b.

1255 Thiem, G.: Die Hydrologie des unteren Elbegebietes, im besonderen der Umgebung Harburgs, Journal für Gasbeleuchtung 1256 und Wasserversorgung, 53 (7), 150-155, 1910a. 
1257 Thiem, G.: Zweckmäßigkeit eines begehbaren Tunnels bei Anlage von Heberleitungen, Journal für Gasbeleuchtung und 1258 Wasserversorgung, 53 (10): 233, 1910b.

1259 Thiem, G.: Die artesischen Bohrungen für die Wasserversorgung der Elbinsel Wilhelmsburg, Journal für Gasbeleuchtung und 1260 Wasserversorgung, 53 (21), 472-473, 1910c.

1261 Thiem, G.: Bevölkerungsgang und Wasserverbrauch der Stadt Leipzig, Journal für Gasbeleuchtung und Wasserversorgung 53 1262 (31), 726-727, 1910d.

1263 Thiem, G.: Die Vorarbeiten für die Erweiterung der Wasserversorgung der Stadt Czernowitz, Journal für Gasbeleuchtung und 1264 Wasserversorgung, 53 (32), 746-747, 1910e.

1265 Thiem, G.: Die Vorarbeiten für die Erweiterung der Wasserversorgung der Stadt Czernowitz, Österreichische Wochenschrift 1266 für den öffentlichen Baudienst, 20, 309-314, $1910 f$.

1267 Thiem, G.: Bau und Betrieb des Magdeburger Versuchsbrunnen am Fläming, Journal für Gasbeleuchtung und 1268 Wasserversorgung, 53 (50), 1136-1142, 1910g.

1269 Thiem, G.: Wahl der Steigung für Heberleitungen, Journal für Gasbeleuchtung und Wasserversorgung, 53 (52), 1191, 1910h.

1270 Thiem, G.: Offene und geschlossene Enteisenungsanlagen und der Enteisenungsbetrieb in Leipzig, Meerane i.S. und Vegesack; 1271 Gesundheits-Ingenieur, 33, 622-624, 1910i.

1272 Thiem, G.: Bevölkerungsgang und Wasserverbrauch der Stadt Leipzig, Technisches Gemeindeblatt, 13 (8), 286-287, 1910j.

1273 Thiem, G.: Grundwasserstände und Niederschlagsmengen in der Umgebung der Leipziger Wasserwerke, Journal für 1274 Gasbeleuchtung und Wasserversorgung, 54 (11), 247-251, 1911a.

1275 Thiem, G.: Grundwasserströme bei Leipzig und deren Ausnützung, Journal für Gasbeleuchtung und Wasserversorgung, 54 1276 (32): 789-796, 1911 b.

1277 Thiem, G.: Bestimmungen der Grundwasserergiebigkeiten auf verschiedenem Wege anlässlich der Vorarbeiten für das neue 1278 Wasserwerk der Stadt M.-Gladbach: Gesundheits-Ingenieur, 34 (24), 438-446, 1911c.

1279 Thiem, G.: Rohrbrunnen mit heraushebbarem Saugrohr, German Patent 245967, 1911d.

1280 Thiem, G.: Einrichtung an einem Wasssermesser mit Woltmannflügel, German Patent 250362, 1911e.

1281 Thiem, G.: Einrichtung zur gleichmäßigen Durchströmung der Flüssigkeitsfäden durch einen Wasssermesser mit 1282 Woltmannflügel, German Patent 239456, $1911 f$.

1283 Thiem, G.: Flüssigkeitsmesser mit Schraubenflügeln, German Patent 250362, 1912a.

1284 Thiem, G.: Der Meßbehälter für das neue Wasserwerk der Stadt Leipzig, Journal für Gasbeleuchtung und Wasserversorgung, 128555 (9), 205-209, 1912b.

1286 Thiem, G.: Die Dichtung von Heberleitungen durch Gummischnurringe, Journal für Gasbeleuchtung und Wasserversorgung, 128755 (17), 402-405, 1912c.

1288 Thiem, G.: Die hydrologischen Zustände beim Wasserwerk Nonnendamm der Stadt Charlottenburg, 56 (10), 226-232, 1913a. 1289 Thiem, G.: Die hydrologischen Vorarbeiten für eine Grundwasserversorgung der Stadt St. Petersburg, Journal für 1290 Gasbeleuchtung und Wasserversorgung, 56, 420-425, $1913 \mathrm{~b}$. 
1291 Thiem, G.: Wirtschaftlicher Abgleich zwischen dem Bezug von Grund- und von Seewasser für die Stadt St. Petersburg; Journal 1292 für Gasbeleuchtung und Wasserversorgung, 56 (20), 467-470, 1913c.

1293 Thiem, G.: Einfluß des Gefälles, der Korngröße und der Lagerung auf die Wasserdurchlässigkeit der Geschiebe, Journal für Gasbeleuchtung und Wasserversorgung, 56 (46), 1134-1136, 1913d.

1295 Thiem, G.: Statistisches und Hydrologisches zur Grundwasserversorgung der Stadt Wasa, Das Wasser, 9 (14), 390-392, 9 1296 (15), 420-422, 1913e.

1297 Thiem, G.: Einfluß des Gefälles, der Korngröße und der Lagerung auf die Wasserdurchlässigkeit der Geschiebe, Das Wasser, 12989 (5), X-Y, (6) X-Y, (7) X-Y, $1913 f$.

1299 Thiem, G.: Abriß über die Grundlagen der Hydrologie, Internationale Zeitschrift für Wasserversorgung, 1 (1): 2-6, 1914a.

1300 Thiem, G.: Die Reinigung des Rohrnetzes des Stadt Taucha, Internationale Zeitschrift für Wasserversorgung, 1 (3), 56-58, 1301 1914b.

1302 Thiem, G.: Abmessungen der Wasserfassung beim dritten Wasserwerk der Stadt Leipzig, Internationale Zeitschrift für 1303 Wasserversorgung, 1 (5), 82-85, 1914c.

1304 Thiem, G.: Die Entsäuerungsanlage der Stadt Meerane (Sachsen), Internationale Zeitschrift für Wasserversorgung, 1 (8), 1311305 135, 1914d.

1306 Thiem, G.: Technische Ratschläge für die Erbauung von Schützengräben, 47 p., Leipzig, Brandstetter, 1915a.

1307 Thiem, G.: Verbindung einer Entsäuerungsanlage mit einer artesischen Quelle, Internationale Zeitschrift für 1308 Wasserversorgung, 2 (4), 27-29, 1915b.

1309 Thiem, G.: Die Versorgung der Orte am Suezkanal mit Wasser, Internationale Zeitschrift für Wasserversorgung, 2 (9), 75-77, $13101915 c$.

1311 Thiem, G.: Wirtschaftlicher Abgleich zwischen Dampf- und Wasserkraft zum Betrieb des dritten Wasserwerks der Stadt 1312 Leipzig, Internationale Zeitschrift für Wasserversorgung, 2 (11), 92-95, 2 (12), 102-104, 1915d.

1313 Thiem, G.: Die geologisch-hydrologischen Zustände der Umgebung Kemptens (Allgäu), Internationale Zeitschrift für 1314 Wasserversorgung, 2 (16), 135-137, 1915e.

1315 Thiem, G.: Die Wasserbezugsorte der Stadt Nizza. Internationale Zeitschrift für Wasserversorgung, 3 (1), 3-6, 1916a.

1316 Thiem, G.: Abdichtung des Filterkorbes eines artesischen Brunnens gegen die Bohrrohrwandung bei der Wasserversorgung 1317 von Wilhelmsburg a.E., Internationale Zeitschrift für Wasserversorgung, 3 (9), 68-71, 1916b.

1318 Thiem, G.: Das wasserrechtliche Verfahren der Stadt Aue im Erzgebirge zwecks Genehmigung eines Grundwasserwerkes, 1319 Internationale Zeitschrift für Wasserversorgung, 3 (16), 126-127, 3 (17), 132-134, 1916c.

1320 Thiem, G.: Keimfreies Wasser fürs Heer, Special issue of Internationale Zeitschrift für Wasserversorgung, 64 p., $1916 \mathrm{~d}$.

1321 Thiem, G.: Technische Ratschläge für die Erbauung von Schützengräben: Drei Aufsätze, 88 p., Leipzig, $1916 e$.

1322 Thiem, G.: Die Anforderungen an eine gute Truppenwasserversorgung, Internationale Zeitschrift für Wasserversorgung, 4 (2), 1323 14-15, 1917a. 
1324 Thiem, G.: Die hydraulischen Wechselbeziehungen von Fluß- und Grundwasser bei Änderung ihrer Spiegellage, Zeitschrift für Wasserversorgung, 4 (20/21), 128-129, (24), 132-133, 1917b.

1326 Thiem, G.: Quellenmenge und Quellenenergie in ihren Beziehungen zur Wasserversorgung, Zeitschrift für Wasserversorgung, 13275 (21/22), 87-89, 1917c.

1328 Thiem, G.: Die Entwicklung des gußeisernen Rohrbrunnens, Zeitschrift für Wasserversorgung, 4 (16/17), 93-96, (18/19): 1071329 110, 1917d.

1330 Thiem, G.: Die Trockenhaltung der Schützengräben - Allgemeinverständlich dargestellt, 71 p., Leipzig, Thiem, 1917e.

1331 Thiem, G.: Der chemische Vorgang bei der Chlorbehandlung des Wassers, Internationale Zeitschrift für Wasserversorgung, 5 1332 (3/4), 13-16, 1918a.

1333 Thiem, G.: Die Versorgung des Rhein-Main-Donau-Großschiffahrtswegs mit Grundwasser, Internationale Zeitschrift für 1334 Wasserversorgung, 5 (7/8), 27-31, 1918b.

1335 Thiem, G.: Der Wert von Unter- und Überflurhydranten, Internationale Zeitschrift für Wasserversorgung, 5 (11/12), 47-50, 1336 1918c.

1337 Thiem, G.: Versuche über Zeitdauer und Wirkung der Wasserchlorung, Internationale Zeitschrift für Wasserversorgung, 5 1338 (13/14), 54-57, 1918d.

1339 Thiem, G.: Hydrologische Erscheinung beim Übertritt von Saalewasser in den Untergrund, Internationale Zeitschrift für 1340 Wasserversorgung, 5 (15/16), 64-67, 1918e.

1341 Thiem, G.: Vorbereitende Massnahmen für eine Erweiterung der Grundwasserversorgung der Stadt Danzig, Zeitschrift für 1342 Wasserversorgung, 6 (1/2), 1-6, 1919a.

1343 Thiem, G.: Die Dupuitsche Formel zur Berechnung vom Wasserrohrleitungen, Zeitschrift für Wasserversorgung, 6 (3/4), 91344 10, (5/6), 17-19, 1919b.

1345 Thiem, G.: Beurteilung der Wässer im Felde Zwecke ihrer Chlorbehandlung, Zeitschrift für Wasserversorgung, 6 (7/8), 281346 30, 1919c.

1347 Thiem, G.: Richtlinien bei der Aufstellung von Strassenbrunnen, Zeitschrift für Wasserversorgung, 6 (9/10), 35-36, 1919d.

1348 Thiem, G.: Die wirtschaftlichen Abmessungen einer Zusatzleitung und die Druckrohrleitung der Stadt Zeitz, Zeitschrift für 1349 Wasserversorgung, 6 (11/12), 41-44, (13/14), 53-54, 1919e.

1350 Thiem, G.: Eintrittswiderstände des Grundwassers bei Rohrbrunnen, Zeitschrift für Wasserversorgung, 6 (17/18), 69-70, 1351 1919f.

1352 Thiem, G.: Mechanische Eigenschaften wasserführenden Sandes, Zeitschrift für Wasserversorgung, 6 (19/20), 77-78, 1919g.

1353 Thiem, G.: Die hydrologischen Vorarbeiten für eine Grundwasserversorgung der Stadt Danzig, Zeitschrift des Vereins 1354 Deutscher Ingenieure, 63 (12), 253-258, 1919h.

1355 Thiem, G.: Die hydrologischen Vorarbeiten für eine Erweiterung der Wasserversorgung der Stadt Halle, Journal für 1356 Gasbeleuchtung und Wasserversorgung, 62 (28), 386-391, 1919 i. 
1357 Thiem, G.: Die hydrologischen Vorarbeiten für eine Grundwasserversorgung der Stadt Danzig, Journal für Gasbeleuchtung und Wasserversorgung, 62 (42), 623-624, 1919j. Thiem, G.: Echtes Grundwasser und künstlich erzeugtes Grundwasser, Journal für Gasbeleuchtung und Wasserversorgung, 62 (42), 624-625, 1919k.

1361 Thiem, G.: Erweiterungsmöglichkeiten der Fassungsanlagen beim Wasserwerk der Stadt Halle [Reply to comment by Winterer 1362 1919], Wasser und Gas 10 (1), 14, 19191. Thiem, G.: Ermittlung des Schadens durch Minderung der Wasserkraft einer Mühle infolge der Anlage einer Wasserleitung, Die Mühle, 36 (9), 509-512, 1919m. Thiem, G.: Die zeitliche Begrenzung der wirtschaftlichen Förderfähigkeit von Wasserrohrleitungen oder welchen zeitlichen Bedürfnissen sollen Rohrleitungen genügen? Zeitschrift für Wasserversorgung und Abwasserkunde, 7 (7/8), 27-30, 1920a. Thiem, G.: Die Bekämpfung von Grundwasserdurchbrüchen in Braunkohlenbergwerken, Zeitschrift für Wasserversorgung und Abwasserkunde, 7 (9/10), 40, 1920b. Thiem, G.: Abweichungen aus der Lotrechten beim Abteufen von gemauerten Sammelbrunnen, Zeitschrift für Wasserversorgung und Abwasserkunde, 7 (11/12), 45-46, 1920c. Thiem, G.: Einschaltung von Wassermessern in Rohrbrunnenanlagen, Zeitschrift für Wasserversorgung und Abwasserkunde, 7 (21/22), 87, 1920d.

Thiem, G.: Hydrologische Methoden, Journal für Gasbeleuchtung und Wasserversorgung, 63 (8), 121-126, 63 (9), 138-142, 1374 1920e.

1375 Thiem, G.: Die Reinigung der Grundwasserfassung der Stadt Zeitz, Wasser und Gas, 1, 3-9, $1920 \mathrm{f}$. Thiem, G.: Hydrologische Betrachtungen bei der Erweiterung des preußischen Bahnwasserwerks Leipzig, Wasser und Gas, 11 (8), 205-210, 1920g. Thiem, G: Ueber hydrologische Vorarbeiten und Mengenbestimmung bei Grundwasserversorgungen, Zeitschrift des Vereins Deutscher Ingenieure, 253-258, 1920h. Thiem, G.: Korrespondenz zu der Diskussion über das Darcysche Gesetz. Journal für Gasbeleuchtung und Wasserversorgung 63 (3), 45, 1920i.Thiem, G.: Der gußeiserne Rohrbrunnen, Thiems hydrologische Sammlung, 1, 33 p., Leipzig, Kröner, 1920j. Thiem, G.: Rutschungserscheinungen beim Abbau von Tongruben und Entwässerung von Tongruben, Tonindustriezeitung, 23, 25, 1920k.

Thiem, G.: Zu der Diskussion über das Darcysche Gesetz, Journal für Gasbeleuchtung und Wasserversorgung, 63 (3), 45, 138519201.

1386 Thiem, G.: Die Bekämpfung von Grundwasserdurchbrüchen in Braunkohlenbergwerken, Journal für Gasbeleuchtung und 1387 Wasserversorgung, 63 (17), 271-272, 1920m.

1388 Thiem, G.: Berechnung der gewinnbaren Grundwassermengen auf dem Fassungsgelände der Stadt Halle, Journal für 1389 Gasbeleuchtung und Wasserversorgung, 64 (9), 132-136, 1921a. 
1390 Thiem, G.: Der Betrieb des Magdeburger Versuchsbrunnens am Fläming, Journal für Gasbeleuchtung und Wasserversorgung, 64 (32), 521-526, (33) 539-543, 1921b.Thiem, G.: Die Einwirkungen von Braunkohlenasche auf das Grundwasser, Braunkohle, 20 (5), 69-73, 1921c. Thiem, G.: Die Aufgaben der Montanhydrologie, Braunkohle, 21 (12), 237-240, 1922a. Thiem, G.: Grubenwasserhaltung und ihre Wirkung auf die Umgebung, Braunkohle, 21 (38), 653-658, 1922b. Thiem, G.: Die Grundwasserströme bei Leipzig und ihre kommunale und industrielle Verwertung, Gesundheits-Ingenieur, 45, 517-522, 1922c. Thiem, G.: Der verkürzte Versuchsbrunnenbetrieb zum Nachweis von Grundwasser, Wasser und Gas, 12 (22), 551-553, 1922d. Thiem, G.: Die praktische Anwendung des verkürzten Versuchsbrunnenbetriebes, Wasser und Gas, 12, 909-912, 1922e. Thiem, G.: Grundwasserforschungen im Oberlauf des Muldeflusses, Das Gas- und Wasserfach, 66 (16), 217-219, 1923a. Thiem, G.: Das Wasserversorgungswesen von Rußland, Das Gas- und Wasserfach, 66 (32), 474-476, $1923 b$. Thiem, G.: Wirkung und Zweck von Schluckbrunnen, Gesundheits-Ingenieur, 46 (34), 331-333, 1923c. Thiem, G.: Die hydrologischen Untersuchungen bei Schwandorf für die Bayerischen Braunkohlenwerke, Braunkohle, 22 (8), 117-121, 1923d. Thiem, G.: Hydrologische Analytik in der Praxis, Die Wasserkraft, 18 (5), 49-50, 1923e. Thiem, G.: Ueberlegung und Erfahrung beim Brunnenumbau, Pumpen- und Brunnenbau, Bohrtechnik, 19, 753-757, $1923 f$. Thiem, G.: Die Grundwasserströme und der Braunkohlenbergbau bei Leipzig, Braunkohle, 23 (7), 134-138, 1924a. Thiem, G.: Die Grundwasserströme und der Braunkohlenbergbau bei Leipzig (Bemerkungen zur Entgegnung des Herrn Dipl.Ing- Vogt, veröffentlicht in „Braunkohle“ XXIII, Nr. 9), Braunkohle, 23 (25), 482-483, 1924b. Thiem, G.: Die hydrologischen Vorarbeiten für die Wasserversorgung der Fabrik der Deutschen Maizena-Gesellschaft in Barby, Journal für Gasbeleuchtung und Wasserversorgung, 67 (10), 117-119, 1924c. Thiem, G.: Die Betriebsanlage des Wasserwerks der Deutschen Maizenafabrik in Barby; Journal für Gasbeleuchtung und Wasserversorgung, 67 (21), 289-291, 1924d.

1413 Thiem, G.: Die Enteisenungsanlage der Fabrik der Deutschen Maizenafabrik in Barby; Journal für Gasbeleuchtung und 1414 Wasserversorgung, 67, 531-533, 1924e.

1415 Thiem, G.: Wirtschaftliche Berechnung einer Dükerleitung (für die Maizena-Fabrik in Barby), Wasser und Gas, 15, 320-326, $14161924 f$.

1417 Thiem, G.: Die Wasserversorgung der Stadt Baku, Wasser und Gas, 15, 349-351, 1924g.

1418 Thiem, G.: Bestimmung der Brunnenergiebigkeit durch Wassermesser, Pumpen- und Brunnenbau, Bohrtechnik, 20, 397-401, 1419 1924h.

1420 Thiem, G.: Der gusseiserne Rohrbrunnen, Thiembrunnen, für Wasserwerke, Thiems hydrologische Sammlung, 1, 33 p., 1421 Leipzig, Kröner, 1925a.

1422 Thiem, G.: Die Technik der Grundwasserversorgung; Das Gas- und Wasserfach, 68 (35), 544-546, $1925 \mathrm{~b}$.

1423 Thiem, G.: Messungsart natürlicher Grundwassergeschwindigkeiten, Die Meßtechnik, 1 (4), 77-81, 1925c. 
1424 Thiem, G.: Durchlässigkeit, Porenraum, Körnung und Lagerung von Kiesen und Sanden, Steinbruch und Sandgrube, 1926 1425 (8/9), 203-205, 1926a.

1426 Thiem, G.: Hydrologische Methoden, Thiems hydrologische Sammlung, 2, 31 p., Leipzig, Kröner, 1926b.

1427 Thiem, G.: Einwandfreies Trinkwasser? Thiems hydrologische Sammlung, 3, 14 pp, Leipzig, Kröner, 1927a.

1428 Thiem, G.: Die Berechnung der Grundwassergeschwindigkeit, Gesundheits-Ingenieur, 50 (29), 538, 1927b.

1429 Thiem, G.: Der gewebelose gusseiserne Rohrbrunnen, Thiemscher Ringfilterbrunnen, für Wasserwerke, Thiems hydrologische 1430 Sammlung, 4, 13 p., Leipzig, Kröner, 1928a.

1431 Thiem, G.: Die Wasserversorgung in Sachsen, Zeitschrift für Kommunalwirtschaft, 18 (15), 2 p., 1928b.

1432 Thiem, G.: Chemische und physikalische Zustandsänderungen gußeiserner Rohrbrunnen im Untergrunde, Das Gas- und 1433 Wasserfach, 71 (51), 1239-1241, 1928d.

1434 Thiem, G.: Hydrologische Erscheinungen im Bereich des Braunkohlenbergwerkes Johanne Henriette, Unseburg, Kreis 1435 Magdeburg, Braunkohle, 27 (43), 971-975, 1928e.

1436 Thiem, G.: Der Filter- und Spülvorgang in offenen Enteisenungsanlagen, Das Gas- und Wasserfach, 71 (35), 852-854, 1928f.

1437 Thiem, G.: Der Filter- und Spülvorgang in offenen Enteisenungsanlagen, Thiems hydrologische Sammlung, 6, 10 p., Leipzig, 1438 Kröner, 1929a

1439 Thiem, G.: Hydrologische Erscheinungen im Bereich des Braunkohlenbergwerkes Johanne Henriette, Unseburg, Kreis 1440 Magdeburg, Thiems hydrologische Sammlung, 7, 5 p., Leipzig, Kröner, 1929b.

1441 Thiem, G.: Grundwasserforschungen in der Umgebung der Stadt Czernowitz (Rumänien), Thiems hydrologische Sammlung, 1442 8, 7 p., Leipzig, Kröner, 1929c.

1443 Thiem, G.: Die Reinigung von Rohrnetzen, Thiems hydrologische Sammlung, 9, 11 p., Leipzig, Kröner, 1929d.

1444 Thiem, G.: Die Verwertung artesischer Wässer für die Wasserversorgung der Stadt Mitau in Lettland, Thiems hydrologische 1445 Sammlung, 10, 11 p., Leipzig, Kröner, 1929e.

1446 Thiem, G.: Chemische und physikalische Zustandsänderungen gusseiserner Rohrbrunnen im Untergrunde, Thiems 1447 hydrologische Sammlung, 11, 6 p., Leipzig, Kröner, $1929 f$.

1448 Thiem, G.: Die Aufsuchung artesischer Grundwasser im Oybingebiet für die Wasserversorgung der Stadt Zittau, Thiems 1449 hydrologische Sammlung, 12, 18 p., Leipzig, Kröner, 1929g.

1450 Thiem, G.: Einrichtung und Entlüftung der neuen Wasserfassung der Stadt Zittau im Oybintal, Thiems hydrologische 1451 Sammlung, 13, 20 p., Hamburg, G. Heymanns Verlag, 1929h.

1452 Thiem, G.: Grundwasserdurchbrüche in Braunkohlenwerken, Thiems hydrologische Sammlung, 14, 11 p., Leipzig, Kröner, 14531929 i.

1454 Thiem, G.: Die Grundlagen des Wasserversorgungswesens nach Thiem, Thiems hydrologische Sammlung, 15, 29 p., Leipzig, 1455 A. Kröner, 1929j.

1456 Thiem, G.: Der Nachweis von Grundwasser für die Versorgung der Stadt St. Petersburg (Leningrad), Thiems hydrologische 1457 Sammlung, 16, 16 p., Leipzig, A. Kröner, 1929k. 
1458 Thiem, G.: Hydrologische Vorbedingungen und Maßnahmen für die Errichtung von Grundwasserwerken für die Großstädte 1459 und Industrien unter Berücksichtigung der Versorgung d. engeren mitteldeutschen Industriegebietes, Thiems hydrologische 1460 Sammlung, 17, 16 p., Leipzig, Alfred Kröner; 19291.

1461 Thiem, G.: Der Nachweis von Grundwasser für die Versorgung der Stadt St. Petersburg (Leningrad), Wasser und Gas, 20 (3), 1462 121-131, 1929m.

1463 Thiem, G.: Grundwasserforschungen in der Umgebung der Stadt Czernowitz (Rumänien), Wasser und Gas, 19 (7), $377-390$, 1464 1929n.

1465 Thiem, G.: Die Verwertung artesischer Wässer für die Wasserversorgung der Stadt Mitau in Lettland; Gesundheits-Ingenieur, $146652(1), 7-10,1929$ o.

1467 Thiem, G.: Die Aufsuchung artesischer Grundwässer im Oybingebiet für die Wasserversorgung der Stadt Zittau; Gesundheits1468 Ingenieur, 52 (14), 209-214, 1929p.

1469 Thiem, G.: Die Bedeutung A. Thiems für das Wasserversorgungswesen, Gesundheits-Ingenieur, 52 (38), 661-665, (39) 6821470 687, 1929q.

1471 Thiem, G.: Die Verwertung artesischer Wässer für die Wasserversorgung der Stadt Mitau in Lettland, Gesundheits-Ingenieur, $147252(1), 7-10,1929 r$.

1473 Thiem, G.: Die Grundlagen der Grundwasserforschung, Thiems hydrologische Sammlung, 18, 34 p., Leipzig, Kröner, 1930a.

1474 Thiem, G.: Die Wirkung der Wasserhaltung des Braunkohlenbergbaues Wolmsdorf und die Wasserversorgung dieser 1475 Gemeinde, Thiems hydrologische Sammlung, 19, 9 p., Leipzig, Kröner, 1930b.

1476 Thiem, G.: Hydraulisches Erkennen und Erkenntnis im Wasserwerksbetrieb, Thiems hydrologische Sammlung, 20, 12 p., 1477 Leipzig, Kröner, 1930c.

1478 Thiem, G.: Das Grundwasser im Wandel der Zeiten, Thiems hydrologische Sammlung, 21, 13 p., Leipzig, Kröner;

1479 Thiem, G.: Grundwassernachweis für die Versorgung der Stadt Bautzen mittels Verstand und mittels Gefühl, Thiems 1480 hydrologische Sammlung, 22, 16 p., Leipzig, Kröner, 1931b.

1481 Thiem, G.: Einfache Berechnung von Wasserrohrleitungen durch Zahl und Bild, Thiems hydrologische Sammlung, 23, 13 p., 1482 Leipzig, Kröner 1931c.

1483 Thiem, G.: Einrichtung an Filterbrunnen beliebiger Bauart zum Einbringen eines chemischen Mittels zwecks Loesung von 1484 Verkrustungen, German patent DE539071C, 1931d.

1485 Thiem, G.: Hydrologische Vorbedingungen zur Errichtung von Grundwasserwerken für die Großstädte und für die Industrie 1486 im engeren mitteldeutschen Gebiet. Deutsche Licht- und Wasserfach-Zeitung 25 (7), 127-133, 1931e.

1487 Thiem, G.: Entwicklungsgeschichtliche Richtlinien der Grundwasserforschung und der Grundwasserversorgung nach dem 1488 Vorbilde Thiems, Deutsche Licht- und Wasserfach-Zeitung 25 (14), 286-295, $1931 \mathrm{f}$.

1489 Thiem, G.: Das Grundwasser im zeitlichen Wandel der Anschauungen, Deutsche Licht- und Wasserfach-Zeitung, 25 (20), 1490 459-463, 1931g. 
1491 Thiem, G.: Die verschiedenen Verfahren der der Auffindung von Grundwasser für die Versorgung der Stadt Bautzen, Deutsche 1492 Licht- und Wasserfach-Zeitung, 25 (25), 553-557, 1931h.

1493 Thiem, G.: Einfache Berechnung von Wasserrohrleitungen durch Zahl und Bild, Thiems hydrologische Sammlung, 23, 13 p., Leipzig, Kröner 1931 i.

1495 Thiem, G.: Verfahren zur Herstellung von säurefesten Überzügen auf Gußstücken, besonders auf Ringfilterkörben, German 1496 patent DRP 542093, 1931j.

1497 Thiem, G.: Das Grundwasser im Wandel der Zeiten, Vom Wasser, 4, 52-64, 1931k.

1498 Thiem, G.: Grundwassernachweis für die Versorgung der Stadt Bautzen mittels Verstand und mittels Gefühl, Wasser und Gas, 149921 (12), 593-601, 19311.

1500 Thiem, G.: Die Bedeutung der Kohle für die Wassereinigung, Wasser und Gas, 31, 1057-1070, 1931m.

1501 Thiem, G.: Einfache Berechnung von Wasserrohrleitungen durch Zahl und Bild, Gesundheits-Ingenieur, 54 (21), 326-329, 1502 1931n.

1503 Thiem, G.: Die Abführung der Luft in gummigedichteten gusseisernen Heberleitungen mit Unterhaubenschiebern für den 1504 Wasserwerksbetrieb, Thiems hydrologische Sammlung, 24, 12 p., Leipzig, Kröner, 1932a.

1505 Thiem, G.: Wasserversorgungsfragen in Nordböhmen und die Vorerhebungen für das neue Grundwasserwerk der Stadt Saaz, 1506 Thiems hydrologische Sammlung, 25, 12 p., Leipzig, Kröner, 1932b.

1507 Thiem, G.: Wasserversorgungsfragen in Nordböhmen und die Vorerhebungen für das neue Grundwasserwerk der Stadt Saaz, 1508 Wasser und Gas, 22 (19/20), 793-800, 1932c.

1509 Thiem, G.: Schnelles und sicheres Verfahren zur Berechnung von Wasserrohrleitungen, Deutsche Licht- und Wasserfach1510 Zeitung, 26 (1), 2-6, 1932d.

1511 Thiem, G.: Die Abführung der Luft in Heberleitungen und die Wirkungsweise eingebauter Schieber, Deutsche Licht- und 1512 Wasserfach-Zeitung, 26 (7), 129-131,1932e.

1513 Thiem, G.: Die hydrologische Bedeutung des Nordabhanges des Jeschkengebirges für die Wasserversorgung der Stadt 1514 Reichenberg in Böhmen, Thiems hydrologische Sammlung, 26, 13 p., Leipzig, Kröner, 1933a.

1515 Thiem, G.: Hydrologisches und Technisches über die Grundwasserversorgung von St. Moritz im Oberengadin, Thiems 1516 hydrologische Sammlung, 27, 34 p., Leipzig, Kröner, 1933b.

1517 Thiem, G.: Hydraulische und pneumatische Feststellungen beim Grundwasserwerk von St. Moritz im Oberengadin, 1518 Monatsbulletin des schweizerischen Vereins von Gas- und Wasserfachmännern, 13(10), 247-251, 1933c.

1519 Thiem, G.: Die hydrologische Bedeutung des Nordabhanges des Jeschkengebirges für die Wasserversorgung der Stadt 1520 Reichenberg in Böhmen, Mitteilungen des Vereins der Naturfreunde in Reichenberg, 55, 13 p., 1933d.

1521 Thiem, G.: Elastischer walzenfoermiger Gummiring zum Abdichten von Muffenrohren, German Patent DE583734C, 1933d.

1522 Thiem, G.: Ausnützung des Grundwasservorkommens im Dolankengebiet für die Versorgung von Reichenberg und seiner 1523 weiteren Umgebung mit Wasser, Thiems hydrologische Sammlung, 28, 11 p., Leipzig, Kröner, 1934a. 
1524 Thiem, G.: Das Vorkommen von Grundwasser und die Berechnung seiner Mengen in der Umgebung von St. Moritz 1525 (Oberengadin); Pumpen- und Brunnenbau, 30 (5), 137-143, 1934b.

1526 Thiem, G.: Die hydraulischen und pneumatischen Feststellungen beim Grundwasserwerk St. Moritz; Pumpen- und Brunnenbau, 30 (5), 169-175, 1934c.

1528 Thiem, G.: Grundwasserströme in und um Leipzig und ihre Verwertung, Thiems hydrologische Sammlung, 29, 31 p., Leipzig, 1529 Kröner, 1935a.

1530 Thiem, G.: Grundwasserströme in und um Leipzig und ihre Verwertung, Thiems hydrologische Sammlung, 29, 31 p., Leipzig, 1531 Kröner, 1935b.

1532 Thiem, G.: Grundwasserströme in und um Leipzig und ihre Verwertung; Braunkohle, 34 (38), 633-639, (39), 653-656, 1935b.

1533 Thiem, G.: Rückschlagklappenventil, German patent DE608721C, 1935c.

1534 Thiem, G.: Unterdükerung der Elbe unterhalb Meißens für die Wasserversorgung der Chemischen Frabrik von Heyden A.-G.;

1535 Das Gas- und Wasserfach, 78 (19), 329-332, 1935d.

1536 Thiem, G.: Grundwasserforschungen im Mulde-Gebiet für die Wasserversorgung der Städte Aue, Zwickau, Meerane, 1537 Leisning, Leipzig und des Mitteldeutschen Industriegebietes, Deutsche Licht- und Wasserfach-Zeitung, 29 (16), 329-331, 1538 1935e.

1539 Thiem, G.: Der gewebelose gußeiserne Rohbrunnen: Thiemscher Ringfilterbrunnen f. Wasserwerke, Thiems hydrologische 1540 Sammlung, 30, 15 p., Leipzig, Kröner, 1936a.

1541 Thiem, G.: Verbundanlage einer Wasserversorgung und einer Stromerzeugung für Samaden (Oberengadin), Thiems 1542 hydrologische Sammlung, 31, 22 p., Leipzig, Kröner.1936b.

1543 Thiem, G.: Die Versorgung der Orte am Suezkanal mit Wasser. Das Gas- und Wasserfach, 79 (7), 103-105, 1936c.

1544 Thiem, G.: Verbundanlage einer Wasserversorgung und einer Stromerzeugung für Samaden (Oberengadin); Monatsbulletin 1545 der schweizerischen Gas- und Wasserfachmänner, 16 (1), 8-15,1936d.

1546 Thiem, G.: Die Unterdükerung der Elbe unterhalb Meißens für die Wasserversorgung der Chemischen Fabrik v. Heyden A.1547 G., Thiems hydrologische Sammlung, 32, 14 p., Leipzig, Techn. Verl. Dr. Ing. G. Thiem, 1937a.

1548 Thiem, G.: Die Trockenhaltung der Schützengräben: Allgemeinverständlich dargestellt, Thiems hydrologische Sammlung, 33, 154971 p., Leipzig, Kröner, 1937b.

1550 Thiem, G.: Absperrschieber mit einer das Schiebergehaeuse durchquerenden und sowohl an ihrem Antriebsende als auch an 1551 dem entgegengesetzten unteren Ende in einer Haube gelagerten Schieberspindel, German patent DE646140C, 1937c.

1552 Thiem, G.: Verbindung einer Wasserhaltung und einer Wasserversorgung bei einem aufgelassenen Tagebau; Braunkohle, 36, 1553 33-38, 1937d.

1554 Thiem, G.: Verbindung einer Wasserhaltung und einer Wasserversorgung bei einem aufgelassenen Tagebau, Thiems 1555 hydrologische Sammlung, 34, 19 p., Leipzig, Kröner, 1938a.

1556 Thiem, G.: Das gelenklose Rückschlagklappenventil für Wasserleitungen, Thiems hydrologische Sammlung, 35, 7 p., Leipzig, 1557 Dieterich, 1938b. 
1558 Thiem, G.: Der Unterhaubenschieber mit Voll- oder Hohlspindel für Wasser- und Gasleitungen, Thiems hydrologische 1559 Sammlung, 36, 8 p., Leipzig, Dieterich, 1938c.

1560 Thiem, G.: Die Beurteilung und die Eigenschaften eines Brunnens nach Güte und Ergiebigkeit, Thiems hydrologische 1561 Sammlung, 37, 11 p., Leipzig, Dieterich, 1938d.

1562 Thiem, G.: Hydrologische Ergebnisse einer Tiefbohrung im Kreidesandstein für die Erweiterung der Wasserversorgung der 1563 Stadt Reichenberg (Böhmen), Thiems hydrologische Sammlung, 38, 19 p., Leipzig, Diederich, 1939a.

1564

1565

1566

1567

1568

1569

1570

1571

1572

1573

1574

1575

1576

1577

1578

1579

1580

1581

1582

1583

1584

1585

1586

1587

1588

1589

1590

Thiem, G.: Die Entwässerung von Sandgruben und Steinbrüchen, Thiems hydrologische Sammlung, 39, 15 p., Leipzig, Dieterich, 1939b.

Thiem, G.: Berechnete und beobachtete Grundwassermengen, International Union of Geodesy and Geophysics, 7th Assembly, Washington D.C., Comptes-rendus et rapports de la reunion de Washington 1939, Comptes rendus des Seances et Rapports, II, 12 p., 1939c.

Thiem, G.: Quellenmenge und Quellenenergie in ihren Beziehungen zur Wasserversorgung, Thiems hydrologische Sammlung, 40, 19 p., Leipzig, Dieterich, 1940a.

Thiem, G.: Keimfreies Wasser fürs Heer, Thiems hydrologische Sammlung, 42, 64 p., Leipzig, Dieterich, $1940 \mathrm{~b}$.

Thiem, G.: Der Salzverdünnungsverfahren zur Ermittlung der Abwassermenge einer Grube, Thiems hydrologische Sammlung, 44, 7 p., Leipzig, Dieterich, 1940c.

Thiem, G.: Berechnete und beobachtete Grundwassermengen, Das Gas- und Wasserfach, 83 (41), 509-513, 1940d.

Thiem, G.: Das Salzverdünnungsverfahren zur Ermittlung der Abwassermenge einer Grube, Braunkohle, 39 (32), 339-340, 1940e.

Thiem, G.: Die Grundlagen der Grundwasserforschung; Pumpen- und Brunnenbau, 36 (15), 355-356, 36 (16), 379-380, 36 (17), 401-402, 36 (18), 427-428, 36 (19), 451-452, 36 (20), 477-478, 36 (21), 505-506, $1940 f$.

Thiem, G.: Die Grundlagen der Grundwasserforschung, Thiems hydrologische Sammlung, 45, 39 p., Leipzig, Dieterich, 1521, 1941a.

Thiem, G.: Abdichtung des Filterkorbes eines artesischen Brunnens gegen die Bohrrohrwandung, Pumpen- und Brunnenbau Bohrtechnik, 37 (16), 522-524, $1941 \mathrm{~b}$.

Thiem, G.: Eintrittswiderstände des Grundwassers bei Rohrbrunnen, Thiems hydrologische Sammlung, 46, 7 p., Leipzig, Dieterich, 1942.

Thiem, G.: Grundwasservorkommen im Land Sachsen, Gas- und Wasserfach, 91 (6), 55-59, 1950.

Thiem, G.: Klassische Hydrologie, Gas- und Wasserfach, 92 (8), 78-80, 1951a.

Thiem, G.: Erhöhung der Durchlässigkeit der Geschiebe durch Schlämmung, Bohrtechnik, Brunnenbau, 2 (4), 92-93, 1951b.

Thiem, G.: Eintrittswiderstände bei Rohrbrunnen, Bohrtechnik, Brunnenbau, 2 (12), 306-308, 1951c.

Thiem, G.: Einwirkung des Braunkohlenabbaues im Bitterfelder Bezirk auf das Grundwasser, WasserwirtschaftWassertechnik, 2 (11), 363-368, 1952. 
1591 Thiem, G.: Die Ermittlung der natürlichen Grundwassergeschwindigkeit, Wasserwirtschaft - Wassertechnik, 3 (5), 167-171, 1592 1953a.

1593 Thiem, G.: Der verkürzte Versuchsbrunnenbetrieb zum Nachweis von Grundwasser, Wasserwirtschaft - Wassertechnik, 3 1594 (XX), 343-XX-171, 1953b.

1595 Thiem, G.: Gesunde und kranke Wasserfassungen, Bohrtechnik-Brunnenbau, 4 (8), 234-237, Berlin, R. Schmidt, $1953 c$.

1596 Thiem, G.: Brunnenergiebigkeit, Bohrtechnik-Brunnenbau, 4(11), 350-352, Berlin, R. Schmidt, $1953 d$.

1597 Thiem, G.: Wirtschaftlicher Durchmesser der Druckrohrleitungen, Bohrtechnik, Brunnenbau, 5 (9), 196-198, 1954.

1598 Thiem, G.: Die Versorgung der Orte am Suez-Kanal mit Wasser, Bohrtechnik, Brunnenbau, 6 (4), 91-93, 1955 a.

1599 Thiem, G.: Hydrologische Vorbereitungen für das neue Grundwasserwerk der Stadt Dessau, Wasserwirtschaft-Wassertechnik, $16005(4), 145-149,1955 b$.

1601 Thiem, G.: Grundwasservorkommen im Land Sachsen; Das Gas- und Wasserfach, 91 (6), 55-59. 1955c

1602 Thiem, G.: Die Grundwasserströme in der Umgebung von Leipzig, 15 p., Schwerin, Töpperwien, 1957.

1603 Thiem, G., Gagneur, B.: Hydrologisia menettelytapoja: luhyt katsaus pohjaveden syntymisestä, etsimisestä ja olemassaolon 1604 toteamisesta [Hydrologic methods: short overview of the genesis, exploration and presence of of groundwater], 69 p., Helsinki, 1605 Gagneur, 1929.

1606 Thiem, G. and Matakiewicz, P.: Die Erweiterung der Wasserversorgung der Stadt Posen, Wasser und Gas, 13 (26), 651-654, 16071923.

1608 Thiem, G. and Meinzer, O. E.: Correspondence and other Records relating to International Committee on Underground Water, 16091936 - 1946. Record Group 57, Entry A1 593, Box 1 Folder: Meinzer and G. Thiem correspondence, U.S. National Archives 1610 \& Records Administration, U.S. Geological Survey: 42 p., 1936-1940.Tügel, F., Houben, G. and Graf, T.: How appropriate is 1611 the Thiem equation for describing groundwater flow to actual wells? Hydrogeology Journal, 24 (8), 2093-2101, 2016.

1612 Versluys, J. J.: Zum Gesetz der Grundwasserbewegung. Internationale Zeitschrift für Wasserversorgung, 2 (2), 14-15, 1915.

1613 Versluys, J.J.: Zur Theorie der Grundwasserbewegung, Journal für Gasbeleuchtung und Wasserversorgung, 62 (7), 81-85, 16141919.

1615 Vieweg, H.: In memoriam Adolf Thiem; Wasserwirtschaft-Wassertechnik, 8 (5), 193-194, 1958a.

1616 Vieweg, H.: Dem bedeutenden Hydrologen Adolf Thiem (1836-1908) anläßlich der 50. Wiederkehr seines Todestages zum 1617 Gedenken; Zeitschrift für angewandte Geologie, 4 (9), 436-438, 1958b.

1618 Vieweg, H.: Wer war Adolf Thiem 1836-1908?, Wasser und Boden, 11(5), 167-168, 1959.

1619 Waring, G. A. and Meinzer, O. E.: Bibliography and index of publications relating to ground water prepared by the Geological 1620 Survey and cooperating agencies, Water-Supply Paper 992, 412 p., 1947.

1621 Weisbach, J.: Lehrbuch der Ingenieur- und Maschinen-Mechanik [Textbook of engineering and machine mechanics], Friedrich 1622 Vieweg, Braunschweig, 1845.

1623 Wenzel, L. K.: Recent investigations of Thiem's method for determining permeability of water-bearing materials, Transactions 1624 of the American Geophysical Union, 313-317, 1932. 
1625 Wenzel, L. K.: Specific yield determined from a Thiem's Pumping-Test, EOS, Transactions American Geophysical Union, 14 1626 (1), 475-477, 1933.

1627 Wenzel, L. K.: The Thiem method for determining permeability of water-bearing sediments and its application to the 1628 determination of specific yield, results of investigations in the Platte River Valley, Nebraska, U.S. Geological Survey Water1629 Supply Paper 679-A., 1936.

1630 Wenzel, L. K.: General Report on Question 3, Determination of runoff and physical conditions of the flow of underground 1631 water in natural or altered ground, the flow being natural or induced, International Union of Geodesy and Geophysics, 7th 1632 Assembly, Washington D.C. Comptes-rendus et rapports de la reunion de Washington 1939, Comptes rendus des Seances et 1633 Rapports, Volume II, 7, 1939.

1634 Wenzel, L. K. (translation by G. Thiem): Durchflußmenge und physikalische Erscheinungen in natürlichen und künstlichen 1635 Bodenschichten, Das Gas- und Wasserfach, 83, 150-153, 1940 [also as Thiems Hydrologische Sammlung 41: 7 p.].

1636 Wenzel, L. K. and Fishel, V. C.: Methods for determining permeability of water-bearing materials, with special reference to 1637 discharging-well methods, with a section on direct laboratory methods and bibliography on permeability and laminar flow, 1638 Water-Supply Paper 887, USGS, 192 p., 1942.

1639 Weyrauch, R.: Die Frage der Grundwasserbewegung, Internationale Zeitschrift für Wasserversorgung, 3 (24), 192-193, 1916. 1640 Winterer, H.: Erweiterungsmöglichkeiten der Fassungsanlagen beim Wasserwerk der Stadt Halle, Wasser und Gas, 10 (1), $10-$ 1641 13, 1919.

1642 Zavadil, J.: Beitrag zur Theorie der Grundwasserabsenkung durch Brunnen, Journal für Gasbeleuchtung und 1643 Wasserversorgung, 58 (50), 739-742, 1915.

1644 Zunker, F.F.H.: Das allgemeine Grundwasserfließgesetz, Journal für Gasbeuchtung und Wasserversorgung, 63 (21), 331-335, 1645 (22) 350-353, 1920. 